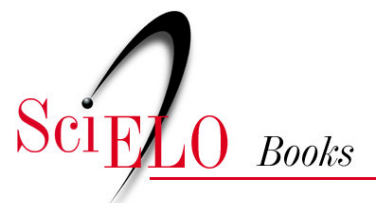

\title{
A endemia hansênica
}

uma perspectiva multidisciplinar

Marcos de Souza Queiroz

QUEIROZ, MS. A endemia hansênica: uma perspectiva multidisciplinar [online]. Rio de Janeiro: Editora FIOCRUZ, 1997. 120 p. ISBN 85-85676-33-7. Available from SciELO Books <http://books.scielo.org>.

\section{@@(@)}

All the contents of this chapter, except where otherwise noted, is licensed under a Creative Commons Attribution-Non Commercial-ShareAlike 3.0 Unported.

Todo o conteúdo deste capítulo, exceto quando houver ressalva, é publicado sob a licença Creative Commons Atribuição Uso Não Comercial - Partilha nos Mesmos Termos 3.0 Não adaptada.

Todo el contenido de este capítulo, excepto donde se indique lo contrario, está bajo licencia de la licencia Creative Commons Reconocimento-NoComercial-CompartirIgual 3.0 Unported. 


\section{A ENDEMIA HANSENICA: UMA PERSPECTIVA MULTIDISCIPLINAR}

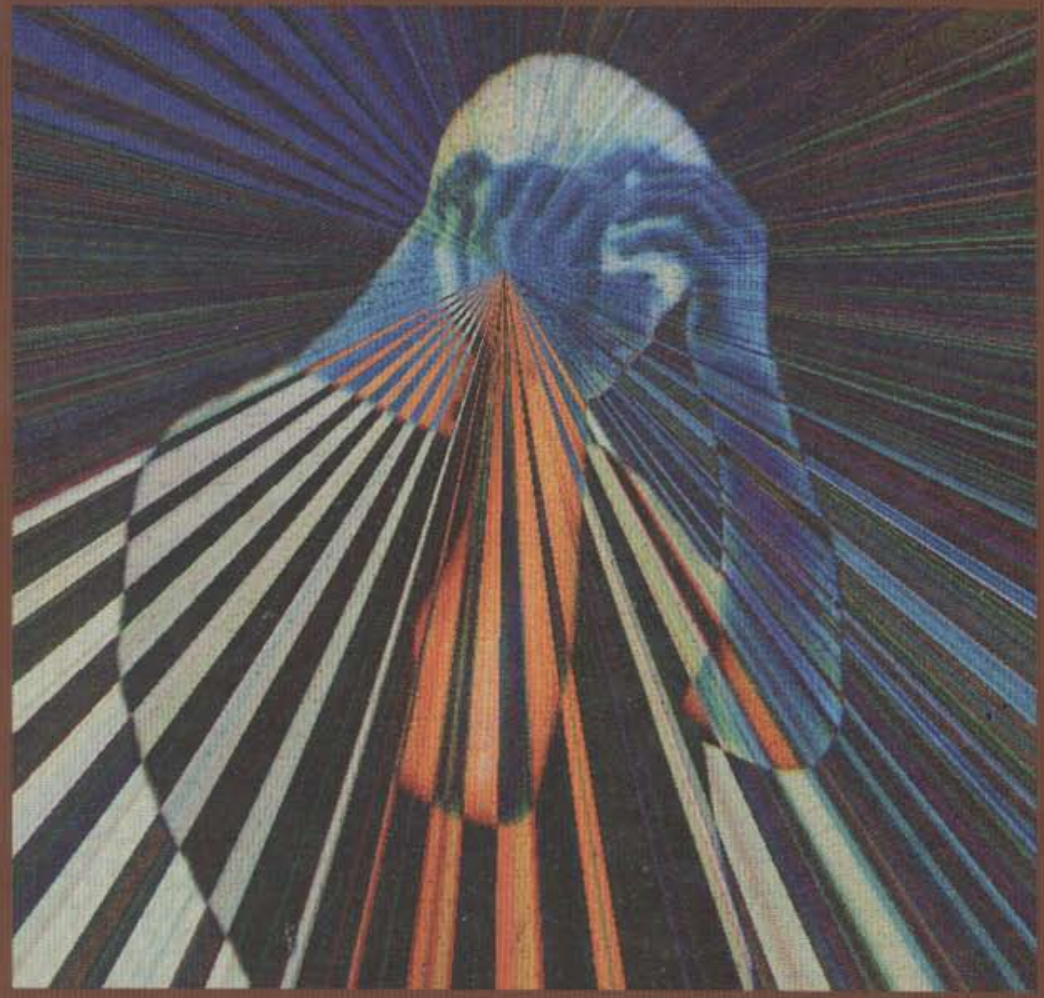

\section{Marcos de Souza Queiroz Maria Angélica Puntel}

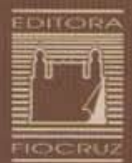




\section{A ENDEMIA HANSÊNICA: UMA PERSPECTIVA MULTIDISCIPLINAR}




\section{FUNDAÇÃO OSWALDO CRUZ}

\section{Presidente}

Eloi de Souza Garcia

Vice-Presidente de Ambiente, Comunicação e Informaçāo

Maria Cecifia de Souza Minayo

\section{EDITORA FIOCRUZ}

Coordenadora

Maria Cecilia de Souza Minayo

Conselho Editorial

Carlos E. A. Coimbra Jr.

Carolina M. Bori

Charles Pessanha

Hooman Momen

Jaime L. Benchimol

José da Rocha Carvalheiro

Luiz fernando Ferreira

Miriam Struchiner

Paulo Gadelha

Paulo Marchiori Buss

Vanize Macêdo

Zigman Brener

Coordenador Executivo

João Carlos Canossa P. Mendes 


\section{A ENDEMIA HANSÊNICA: UMA PERSPECTIVA MULTIDISCIPLINAR}

\section{MARCOS DE SOUZA QUEIROZ}

Ph.D. pela Universidade de Manchester, Inglaterra, pesquisador do Núcleo de Estudos Psicológicos e professor permanente do curso de pós-graduação em saúde mental do Departamento de Psicologia Médica e Psiquiatria - FCM/UNICAMP, Campinas, Săo Paulo.

\section{MARIA ANGÉLICA PUNTEL}

Mestre em Enfermagem, Docente do Departamento de Enfermagem da Faculdade de Ciências Médicas e Biológicas da UNICAMP, Campinas, São Paulo.

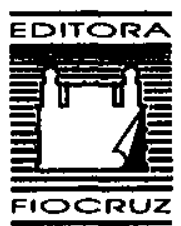


Copyright (ㅇ 1997 by

Todos os direitos desta edição reservados à

EOITORA FIOCRUZ

ISBN: 85-85676-33-7

Projeto Gráfico e Editoraçāo Eletrônica:

Heloisa Diniz

Capa:

Heloisa Diniz

Revisão e Preparação de Originais:

Marcionilio Cavalcanti de Paiva

Supervisão Editorial:

Walter Duarte

Supervisāo Gráfica:

Davi Henrique de Lima

Catalogação-na-fonte

Centro de Informaçăo Científica e Tecnológica

Biblioteca Lincoln de Freitas Filho

Q3e Queiroz, Marcos de Souza

A endemia hansênica: uma perspectiva multidisciplinar. / Marcos de Souza Queiroz; Maria Angélica Puntel - Rio de Janeiro : FIOCRUZ, 1997.

$120 \mathrm{p}$.

1. Hansenfase. 1. Puntel, Maria Angélica.

CDD. - 20. ed. -616.998

1997

EDITORA FIOCRUZ

Rua Leopoldo Bulhöes, 1480, Térreo - Manguinhos

21041-210 - Rio de janeiro - RJ

Tel.: 590-3789 ramal 2009

Fax.: (021) 280-8194 


\section{AUTORES}

MARCOS DE SOUZA QUEIROZ - é autor de dois outros livros, um sobre representaçōes sociais sobre saúde e doença e outro sobre psicologia dos tipos humanos, além de cerca de 40 artigos e capítulos de livros em meios de divulgação científica nacional e internacional, nas áreas da Sociologia, Antropologia e Psicologia Social. Formado em Ciências Sociais e com mestrado pela UNICAMP, concluiu seu doutorado em 1982 na Universidade de Manchester, Inglaterra. Desde 1983 atua como pesquisador e professor em programas de graduação e pós-graduação, inicialmente no Núcleo de Estudos de Políticas Públicas e Núcleo de Estudos Psicológicos e, atualmente, no Departamento de Psicologia Médica e Psiquiatria da Faculdade de Medicina da UNICAMP. As Ciências Sociais voltadas à Saúde e Medicina constituem o principal eixo de suas preocupaçōes acadêmicas e científicas.

MARIA ANGÉlICA PUNTEL - formada em Enfermagem pela Universidade de São Paulo, concluiu seu mestrado na área de Enfermagem Fundamental e, atualmente, é doutoranda na área de Saúde Coletiva do Departamento de Medicina Preventiva da Faculdade de Ciências Médicas da UNICAMP. É professora do Departamento de Enfermagem da Faculdade de Ciências Médicas da UNICAMP e, desde 1988, atua na área de hanseníase realizando treinamento, ministrando cursos teóricos e práticos $\mathbf{e}$ dando assistência a doentes portadores da moléstia na rede básica de serviços de saúde do município de Campinas. 


\section{SUMÁRIO}

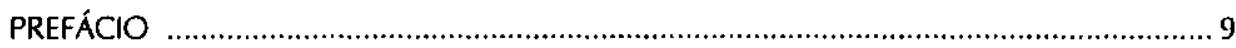

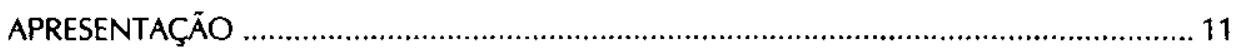

1. INTRODUÇÃO TEÓRICA E METODOLÓGICA AO PROBLEMA DA HANSENIASE

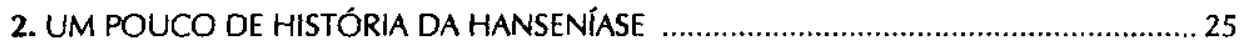

3. A SITUAÇÃO EPIDEMIOLÓGICA DA HANSENÍASE NO BRASIL E EM CAMPINAS

4. OS MEIOS DE CONTROLE DA HANSENÍASE EM CAMPINAS

5. CARACTERIZAÇÃO SOCIOLÓGICA E REPRESENTAÇÕES SOBRE O MODO

DE VIDA

6. REPRESENTAÇÕES SOBRE SAÚDE E DOENÇA

7. REPRESENTAÇŌES SOBRE BENZIMENTO, AUTOMEDICAÇÃO \& MEDICINAS ALTERNATIVAS

8. DIAGNÓSTICO, TRATAMENTO E AVALIAÇÃO DO SERVIÇO

9. RELACIONAMENTO SOCIAL, FAMILIAR E DE TRABALHO - EXPECTATIVAS, ESTRATÉGIAS E ATITUDES

CONCLUSĀO

REFERÊNCIAS BIBLIOGRÁFICAS 


\section{PREFÁCIO}

O livro de Marcos de Souza Queiroz e de Maria Angélica Puntel desconstrói pelo menos três verdades mais ou menos consagradas no campo da medicina e da Saúde Coletiva.

Em primeiro lugar, chama a atenção para o relativo olvido a que a hanseníase foi relegada. Seriam quase seiscentos mil brasileiros doentes e, mesmo assim, verifica-se uma progressiva deterioração tanto da atençăo curativa e reabilitadora, quanto do Programa Sanitário de Controle dessa moléstia. A cada ano, há aumento da prevalência e o Brasil já ocupa um vergonhoso quarto lugar mundial entre os países onde ainda há hansenianos. Apesar de ser uma doença com mecanismos de cura e de prevenção sobejamente conhecidos; apesar do controle dessa enfermidade depender de projetos com pequena incorporação tecnológica - o tratamento é ambulatorial, a poliquimioterapia é altamente eficaz etc. -, o Sistema Único de Saúde năo tem demonstrado capacidade de circunscrever este problema. Ao contrário.

E não o tem porque o sucesso desse programa dependeria de equipes multidisciplinares motivadas e bem treinadas; dependeria da continuidade administrativa destes projetos e isto o SUS não tem conseguido fazer com competência e constância. O sistema público, em geral, cuida mal de seus profissionais. Funcionários públicos são, até hoje, o novo bode expiatório dos fracassos governamentais.

$\mathrm{Em}$ segundo lugar, os autores demonstram que apesar da boa intenção do discurso descentralizador do SUS e da suposta correçāo teórica da diretriz que sugere que a Rede Básica deveria assegurar atenção integral, a qualidade do cuidado aos hansenianos vem decaindo. Ou seja, lançar a hanseníase na vala comum dos outros problemas de saúde, de fato, deteriorou a assistência a estes doentes.

Em certa medida, demonstram uma tese que é possível de ser também verificada em outras enfermidades de alta prevalência, de caráter endêmico ou epidêmico e que demandam sistemas de atençăo complexos. Note-se que aqui a complexidade, em geral, está referida ao trabalho humano e não necessariamente a equipamentos. Este seria o caso da AIDS, da Saúde Mental e até mesmo do dengue. Somente os municípios que destacaram estes problemas do conjunto da demanda 
conseguiram articular programas eficazes. Ou seja, demonstra-se que a lógica da Clinica e da Saúde Pública têm diferenças importantes. No caso, a clínica está obrigada a atender a demanda; seja o caso raro ou seja o enfermo portador de uma patologia de massa, igualmente, aos dois extremos dever-se-ia assegurar atendimento. No entanto, a Saúde Coletiva estaria obrigada a priorizar e destacar alguns problemas entre outros. É impossivel um país ou um município articular programas de controle contra todas as enfermidades preveniveis ao mesmo tempo. A história tem demonstrado que a capacidade de erradicar ou de controlar problemas de saúde depende de concentração intensiva de atividades. Portanto, caberia sempre se discutir as prioridades em Saúde Pública, ainda que não se descarte nunca o direito universal à saúde. No Brasil de hoje, sem dúvida, a hanseníase deveria constar entre as prioridades a serem destacadas. Ao lado da AIDS, da mortalidade infantil em algumas regiôes, da mortalidade violenta de adultos jovens em outras etc.

De qualquer forma, os autores desvendam este paradoxo do SUS. Promete-se qualidade e universalidade e assiste-se, na prática, à degradação de um programa que chegou a desfrutar de alguma respeitabilidade no passado.

Por último, há um questionamento explícito do tradicional enfoque mecânico e biologicista predominante no saber e na prática médica. Usando metodologia originária da Antropologia Social e Cultural, os autores exploram as representações e estratégias de pacientes e dos trabalhadores de saúde envolvidos com a hanseníase e desvendam a trama imbricada que é essa doença. Estigma, preconceito, depressão, negação da enfermidade, desconfiança, lesōes orgânicas, mal-estar, tudo aparece misturado na demanda de doentes e comunicantes. Em decorrência, mesmo havendo cura para a hanseníase, verifica-se que o tratamento é muito mais complexo do que a simples administração de drogas, ainda quando bem indicadas. Há as dimensões sociocultural e subjetiva agindo de maneira tão decisiva quanto a orgânica. Ou seja, a equipe de saúde estaria obrigada a trabalhar com tudo isso: remédios, curativos, orientação, desemprego, desistência, descuido, ignorância, agressividade, vontade de cura, apoio psicológico etc.

A metodologia de investigação é interessante e vem reforçar a nova e salutar onda de pesquisas em saúde com enfoque sobre os sujeitos em ato: no caso, profissionais, pacientes e seus familiares. No entanto, os autores não ficaram presos ao impressionismo das entrevistas. Na realidade, trataram de analisá-las considerando achados oriundos de estudos de corte mais histórico-estrutural.

Concluindo, trata-se de um Estudo de Caso que fala e questiona muitos outros casos. Vale a pena ler e estudar este livro, que a partir da hanseníase fala sobre a Saúde Pública.

Prof. Dr. Gastão Wagner de Souza Campos Chefe do Departamento de Medicina Preventiva e Social/ FCM/UNICAMP 


\section{APRESENTAÇÃO}

O tema central deste livro concentra seu foco nas representações e estratégias que tanto os pacientes e seus familiares (comunicantes) como os agentes e especialistas de saúde (médicos, enfermeiros e atendentes) formulam a respeito da hanseníase nos dias de hoje. Dados sobre esta doença, obtidos a partir de fontes secundárias das Secretarias de Saúde do Estado de São Paulo e do município de Campinas, além de dados do Ministério da Saúde, também foram subsídios importantes nesta análise.

O trabalho de pesquisa necessário para a realização desta obra foi efetuado a partir do esforço de promover uma síntese interdisciplinar entre as ciências sociais e a Saúde Pública. A presença de uma enfermeira habituada a tratar doentes de hanseníase mostrou-se crucial no que diz respeito à qualidade dos dados coletados com grupos amostrais de doentes e de comunicantes.

O objetivo central do estudo é compreender a maneira pela qual o doente de hanseníase tem enfrentado o problema de manutenção e recuperação da saúde. Trata-se de captar, no interior das condições de vida e de trabalho, as estratégias que permitem adaptação ao meio social e familiar, subsistência e convivência com a doença. Atenção especial é dada às estratégias de consumo de serviços médicos e às representaçōes sobre saúde, doença e terapêutica, envolvendo pacientes, agências oficiais e não oficiais de saúde.

A pesquisa contempla também os comunicantes, ou seja, o meio familiar intradomiciliar do doente. A importância do seu papel no desenvolvimento da hanseníase é inquestionável e, em considerável medida, a sua atitude influi no resultado do tratamento. $O$ estudo do comunicante justifica-se também porque, além de parte fundamental do mundo do paciente, ele é um elo importante na cadeia do processo infeccioso no controle da endemia.

Qualquer que seja o alcance de um programa de saúde oferecido pelo setor público, ele será inevitavelmente interpretado, avaliado e manipulado pelos indivíduos a quem ele se destina, de acordo com um determinado padrão sociocultural. Nesse contexto, ao focalizar esta realidade, pretendemos contribuir não só para o 
desenvolvimento da área das ciências sociais aplicadas à medicina, numa perspectiva acadêmica, como também para o sucesso da implantação do próprio programa de saúde, numa perspectiva de prática social aplicada à saúde pública.

No que se refere às condições de tratamento médico da hanseníase, que se desenvolve a partir de um programa específico posto em prática pelo Ministério da Saúde, envolvendo ainda as Secretarias de Estado e Municipais da Saúde, a pesquisa aborda não só a política pública em níveis federal, estadual e municipal relativa à doença, como também a percepçăo do problema pelos funcionários (médicos, enfermeiros, assistentes sociais) encarregados de promover o seu controle.

Visto ser a hanseníase uma doença curável em todas as suas formas, e a vigilância de contatos uma atividade importante preconizada pelo Ministério da Saúde em suas instruções normativas, faz-se necessário um trabalho de pesquisa sociocultural junto aos doentes e aos comunicantes, como forma de contribuir para o controle da endemia. Este estudo assume que, para realizar este propósito, a medicina precisaria ampliar a sua base reducionista biológica e projetar um enfoque que inclua o processo saúde e doença como uma dimensão que está inevitavelmente impregnada de fatores sociais e culturais.

O livro consiste, além da introdução e da conclusão, de nove capítulos que cercam o problema da hanseníase a partir de uma perspectiva histórica, epidemiológica, sociológica e antropológica. No primeiro capítulo, levantamos o problema central da pesquisa, apresentamos a metodologia de investigação e tecemos algumas considerações teóricas que influenciaram a coleta de material, a organização dos dados e a análise dos resultados. No segundo, introduzimos um breve panorama sobre a história da saúde pública no Brasil, numa perspectiva mais geral, e sobre a história da hanseníase, num plano mais específico. No terceiro, abordamos o problema da hanseníase no Brasil e em Campinas sob um ponto de vista estritamente médico e epidemiológico. No quarto, oferecemos uma visão sobre os meios de controle da hanseníase em Campinas. Nele, o processo de municipalização dos senviços de saúde é trazido à tona, tendo em vista situar o problema desta doença numa ótica organizacional mais ampla. No quinto, caracterizamos sociologicamente os grupos amostrais estudados e abordamos suas representações gerais sobre seu modo de vida. São focalizados aqui as tensões e estresses próprios da situação de pobreza em que vive a maioria dos indivíduos estudados. No sexto, tratamos das representaçōes sociais a respeito do tema saúde e doença em geral e a hanseníase, em particular. São estudados aqui crenças sobre contágio, equilíbrio e manifestaçōes físicas e psicológicas de saúde, doença, tratamento e cura. No sétimo, focalizamos as representaçōes sociais sobre medicinas alternativas relacionadas tanto com o benzimento e religião como com práticas tradicionais caseiras baseadas, principalmente, em chás de ervas medicinais. No oitavo, concentramos a atenção sobre as representações sociais a respeito do diagnóstico e do conhecimento que o paciente demonstra sobre a hanseníase. Aqui, colocamos em evidência e analisamos fatores tais como: a desinfor- 
mação de médicos e pacientes sobre os sintomas da doença, a reação psicológica e cultural ao diagnóstico e ao tratamento, $\mathrm{e}$ a avaliação que os usuários fazem do serviço médico oficial. No nono, estudamos o relacionamento social, familiar e de trabalho de pacientes de hanseníase. Suas expectativas, atitudes e estratégias com relação ao tratamento e à cura receberam atenção especial, principalmente no que diz respeito ao processo de estigma e às estratégias postas em prática para lidar com esta situação.

Na conclusão deste trabalho, com base tanto na postura teórica desenvolvida ao longo do livro como nos dados empíricos levantados pela pesquisa de campo, além de outras questōes específicas, desenvolvemos uma análise crítica do paradigma médico positivista empregado no controle desta endemia pelos programas de saúde pública, ao mesmo tempo que propomos uma dimensão do processo saúde e doença que inclua fatores subjetivos e socioculturais.

Agradecemos aos companheiros de trabalho do Núcleo de Estudos de Políticas Públicas e do Núcleo de Estudos Psicológicos que estimularam a concepção e o andamento deste trabalho; à Claudete $R$. $O$. Landy, que realizou a revisão do texto original; à FIOCRUZ, principalmente através dos professores Carlos E. Coimbra Jr. (que colocou um valioso material de pesquisa à nossa disposição) e Paulo C. Sabroza que, numa longa entrevista realizada na fase inicial da pesquisa, expôs sua ampla experiência sobre hanseníase e influenciou as fases posteriores da pesquisa; à $F A$ PESP, que financiou o andamento deste projeto; ao CNPq, que contribuiu com uma bolsa de produtividade em pesquisa; $e$, finalmente, aos pacientes, seus familiares $e$ aos profissionais da saúde entrevistados, que, com o relato de suas experiências de vida e de profissão, contribuíram decisivamente para a qualidade deste trabalho. 


\section{INTRODUÇÃO TEÓRICA E METODOLÓGICA AO PROBLEMA DA HANSENIAASE}

A hanseníase é uma moléstia de evolução prolongada com grande potencial incapacitante. Atinge principalmente as camadas mais pobres da populaçăo e apresenta endemicidade em todas as macrorregiōes brasileiras. Como veremos, o ocultamento da doença, inclusive a recusa a se submeter a um tratamento médico, é comum, não só devido ao estigma e aos preconceitos existentes em torno de sua manifestaçăo e à dificuldade de acesso aos serviços de saúde, como também às representaçōes sobre o corpo e as condiçōes de vida e de trabalho da população trabalhadora afetada.

Estudos sobre a dimensão sociocultural da hanseníase no Brasil são raros. Destacam-se, nesse sentido, os filmes do professor ítalo Tronca, do Departamento de História da UNICAMP, que, através de entrevistas com médicos e pacientes, reconstitui admiravelmente o drama do confinamento compulsório nos antigos leprosários no Estado de São Paulo.

Recentemente, a Editora Fiocruz lançou Hanseníase, de Lenita Claro,' livro este que apresenta alguns pontos em comum com a nossa abordagem no que se refere à análise qualitativa das representações sobre a doença. A possibilidade de comparação dos dois contextos em que se desenrolam as pesquisas, em trabalhos posteriores, deverá contribuir consideravelmente para a compreensão deste problema em escala nacional.

Devido ao fato de a hanseníase ser uma doença erradicada nos paises desenvolvidos, os poucos estudos disponiveis sobre esse tema na área de ciências sociais e de psicologia social referem-se a contextos subdesenvolvidos e são bastante restritos. Alguns desses trabalhos serão comentados no desenrolar deste livro.

Não obstante a carência de preocupação com este campo de estudo, trata-se de uma área privilegiada para uma investigação antropológica (antropologia da me-

1 CLARO, L. B. L. Hanseníase: representaçōes sobre a doença. Rio de Janeiro: Ed. Fiocruz, 1995. 
dicina), sociológica (sociologia da saúde), histórica e de psicologia social, na medida em que lida com um problema que, além de médico, penetra profundamente no imaginário popular, inclusive dos próprios profissionais da medicina e da saúde. Acreditamos que o foco dirigido pelas disciplinas referidas acima a uma endemia, que tem sido tratada quase que exclusivamente pela epidemiologia, deve contribuir para refinar a compreensão existente sobre este problema e, com isso, aumentar a possibilidade de controlá-lo.

É redundante afirmar aqui a importância de um conhecimento mais profundo desta realidade, não só para o desenvolvimento dessas áreas acadêmicas como também para a otimização dos senviços de saúde. É suficiente lembrar, em primeiro lugar, que, no caso do Brasil, a hanseníase atinge um número superior a quinhentas mil pessoas, grande parte das quais em idade produtiva, influenciando negativamente o seu trabalho, a formação da sua família e a sua integração social. Em segundo lugar, como mostraremos adiante, várias pesquisas sobre o assunto mostram que há indícios suficientes para se acreditar que o número de doentes está aumentando, gerando, com isso, um verdadeiro problema de saúde pública.

\section{METODOLOGIA DE INVESTIGAÇÃO}

A pesquisa de campo transcorreu durante o ano de 1993. Foram pesquisadas 34 famílias, envolvendo 45 doentes de hanseníase e 164 comunicantes. Deste universo, foram diretamente entrevistados 90 indivíduos, sendo 33 doentes e 57 comunicantes. No Centro de Saúde I (Policlínicas I), que concentra cerca de 95\% do atendimento à hanseníase na região de Campinas, foram entrevistados oito profissionais, sendo três médicos, três enfermeiras e dois auxiliares de saúde. Outros especialistas em hanseníase da Prefeitura Municipal de Campinas, da Secretaria Estadual de Saúde e da UNICAMP, totalizando cinco profissionais, foram também entrevistados.

A entrevista semi-estruturada aplicada a pacientes, comunicantes, agentes de saúde e especialistas foi o principal instrumento metodológico da pesquisa. $O$ motivo da entrevista foi explicado logo no início da mesma. $O$ argumento, coleta de material para um livro, foi, em geral, aceito sem problemas pelo entrevistado. Os entrevistadores foram freqüentemente confundidos com agentes de saúde, ocorrendo pressões para a obtenção de informaçōes sobre a doença e o tratamento. Sempre que isso ocorreu, voltava-se a questão para o entrevistado, numa recusa a assumir este papel. É evidente que, se houvesse concessões nesse sentido, a pesquisa seria prejudicada pelas expectativas e atitudes geradas, que muito provavelmente iriam interferir negativamente em seus propósitos.

Não houve qualquer limitação no que diz respeito à duração e quantidade de entrevistas dirigidas para um determinado ator ou grupo de atores. Em geral, elas duraram duas horas, e em cerca de $30 \%$ dos casos mais de uma entrevista foi produ- 
zida para o mesmo grupo familiar ou com o mesmo agente ou técnico de saúde, com o intuito de checar certas indagações produzidas no primeiro contato.

As entrevistas com doentes e com comunicantes foram produzidas à noite, após a jornada de trabalho, momento em que era mais fácil reunir a família. Em todas as ocasiões, com a exceção de uns poucos doentes que viviam isolados, elas foram realizadas coletivamente, reunindo a maior parte possivel de membros da família maiores de dezesseis anos. Todas as entrevistas foram gravadas e, posteriormente, transcritas.

Na maioria das vezes, as entrevistas transcorreram num ambiente descontraído e acolhedor. Como já mencionado, a presença de uma enfermeira foi importante para a receptividade aos entrevistadores que, inicialmente, eram reconhecidos como membros da equipe de saúde. O fato de a entrevista estar sendo realizada em presença de outros membros familiares foi em geral positivo, uma vez que estimulava e checava as respostas do entrevistado. Freqüentemente, os membros da família participavam e opinavam a respeito das questōes propostas, levando os entrevistadores a participarem como promotores improvisados de uma dinâmica de grupo. Nestas ocasióes, a técnica utilizada foi concentrar o questionamento no entrevistado sem desestimular a participação dos demais. Os comunicantes foram selecionados para serem entrevistados a partir de seu desempenho nesta primeira entrevista. Em algumas ocasiōes, o contato com os comunicantes ocorreu no mesmo dia e, em outras ocasiōes, em dias diferentes da entrevista com o paciente.

As famílias estudadas foram constituídas a partir de doentes sob tratamento poliquimioterápico, inscritos no programa de controle de hanseníase do Centro de Saúde I (Policlínicas I) de Campinas. Cinco pacientes que se submetiam a tratamento tradicional (todos eles parentes intradomiciliares dos pacientes originalmente selecionados para entrevista), foram incluídos na amostra. Como a poliquimioterapia está trazendo um novo alento ao tratamento da hanseníase com a perspectiva de redução significativa no tempo de tratamento e aumento nos índices de cura, há tanto da parte da população doente como da equipe médica um maior envolvimento com o tratamento e uma expectativa maior de cura. Esta hipótese foi confirmada em conversas iniciais com a equipe do Centro de Saúde e com as primeiras entrevistasteste, os quais envolveram doentes que se submetiam a um tratamento tradicional.

A partir do pressuposto de que um número em torno de 30 famílias iria constituir uma amostra adequada para os propósitos desse projeto de pesquisa, sortearam-se, entre os doentes, 70 nomes. Os 34 efetivamente pesquisados o foram a partir da disponibilidade, aceitaçāo e disposição de contribuir para a pesquisa. Em geral, as famílias mostraram-se bastante motivadas para a concessão de entrevistas, de modo que este número foi obtido a partir das primeiras 41 tentativas.

Diante do pressuposto de que apenas uma minoria se interessa em explicar, entender e questionar a sua própria experiência de vida, esta minoria, ou seja, o universo amostral da pesquisa, consistiu no seu principal objeto de interesse. A me- 
todologia antropológica já demonstrou, em várias ocasiōes, a utilidade deste enfoque metodológico, uma vez que permite a expressão do que a maioria da população experimenta, sente, faz e pensa, mas não expressa dentro de um quadro de referência formalizado e coerente, deixando esta tarefa para os seus "intelectuais".,

$O$ roteiro de entrevista com os pacientes foi previamente testado, tendo chegado a oito temas básicos, a saber: situação de vida, trabalho e lazer; cosmologia sobre saúde e doença; diagnóstico e tratamento da hanseníase; conhecimento e avaliação da hanseníase; benzimento, automedicação e medicinas alternativas; relacionamento social, familiar e de trabalho; avaliação do governo, do serviço e da medicina; expectativas, estratégias e atitudes.

A pesquisa com a equipe de saúde contemplou a grande maioria dos profissionais (médicos, enfermeiras e atendentes) que se dedicam ao combate à hanseníase no Centro de Saúde I de Campinas. Apenas uma assistente social e duas enfermeiras dessa equipe não foram entrevistadas. $O$ roteiro da entrevista com esses agentes incluiu, além dos dados pessoais e profissionais de cada entrevistado, sua visão do problema, do serviço, das formas terapêuticas e da vontade política do governo em lidar com a situação.

Os aspectos epidemiológicos e históricos da hanseníase bem como os dados gerais e de saúde referentes ao município de Campinas foram analisados a partir de dados provenientes de documentos internos às repartiçōes públicas, de textos legislativos, regulamentares e outras fontes secundárias. Contribuíram também para a geração desse tipo de dado, as entrevistas realizadas com técnicos especialistas da Prefeitura Municipal de Campinas e com professores do Departamento de Medicina Preventiva da UNICAMP. ${ }^{3}$

Um princípio teórico fundamental presente neste livro considera que o saber, as representações, as ideologias, assim como os comportamentos e as práticas individuais ou coletivas só têm sentido e adquirem significado no interior de um determinado contexto socioeconômico e cultural. Este, por sua vez, manifesta-se, evidentemente, em diferentes níveis de realidade, ou em diferentes escalas. $O$ nível macrossocial determina, no caso do foco gerado por este projeto, como se realizam as politicas de saúde e como estas políticas chegam efetivamente a se materializar em programas e em meios assistenciais. Ainda neste nível, as condições de trabalho, de salário e de vida em geral são também indispensáveis para a compreensão do processo saúde e doença. No nível local, a situação de uma cidade, de um bairro ou de uma rede social específica pode conter determinantes importantes que configuram as condiçōes efetivas que cercam a questão da saúde e da doença.

2 TURner, V. W. Muchona the hornet, interpreter of religion. In: CASACRANDE, J. B. (Ed.). In the Company of Man. New York: Harper, 1960.

3 Agradeço em especial aos professores Gastāo Wagner de Souza Campos e Emerson Elias Merhy, que transmitiram, em longas entrevistas, as suas experiências quando serviram à Secretaria Municipal de Saúde de Campinas. 
Diante destes condicionantes gerais, $\mathrm{o}$ individuo tende a se organizar no sentido de preservar sua saúde e sua vida. Esta organização ocorre em diversas camadas, tendo o sindicato, as associações de bairro ou as diversas religiỏes um papel dos mais importantes na formação de visões de mundo e de práticas relativas à saúde e à doença. Essa organização também ocorre em nível informal de vizinhança e familiar, tendo em vista uma postura menos política e mais descontraída, em função de uma adaptação à realidade vivida mais imediata.

Temos, portanto, dois tipos de influência organizadora que atuam sobre o saber, as representaçōes e as práticas diante da doença em geral, e da hanseníase em particular: a influência que vem de cima e de fora, referente ao modo de produção $\mathrm{e}$ às condiçóes socioeconômicas presentes no plano nacional, estadual e municipal e a influência que vem de dentro do raio de ação individual, qual seja, o espaço social que permite a um indivíduo reagir, manipular ou se adaptar num nível prático e simbólico à realidade que the é imposta.

Esta perspectiva impõe duas posturas analíticas diferentes, mas complementares: a primeira parte do geral para o particular, num processo dedutivo, enquanto a segunda parte do particular para o geral, num processo indutivo. Embora este projeto esteja interessado em captar estas duas dimensões, o seu escopo maior privilegia o segundo aspecto. Nesse sentido, a metodologia empregada refere-se à preocupação de focalizar um universo relativamente pequeno e, assim, extrair padrōes válidos para uma realidade mais ampla.

Além de se referir a essas questōes de ordem teórica, o estudo mostra uma dimensão eminentemente prática, na medida em que, ao enfatizar o aspecto sociocultural da doença, promove um paradigma médico voltado ao ser humano num sentido mais global e holístico que inclui a biologia, mas não se reduz a esta dimensão. Como veremos no decorrer deste trabalho, a grande maioria dos casos pesquisados revela que antes do diagnóstico da doença, o paciente foi tratado por vários médicos a partir de diagnósticos equivocados, revelando um conhecimento precário dos profissionais da saúde sobre o assunto. Veremos, nesse sentido, que esse desinteresse se ajusta a um paradigma predominante que, contido na educação médica $e$ na política oficial de saúde, ao invés de contribuir para ampliar o sentido de saúde e promover ações efetivas de controle da doença, oferece uma perspectiva distorcida da realidade em sintonia com práticas de eficácia reduzida.

\section{ALGUMAS CONSIDERAÇŌES TEÓRICAS}

De um modo geral, a concepção positivista da ciência moderna confere uma preponderância explícita ao método enquanto modelo lógico-conceptual que enquadra e seleciona os dados no interior de seus próprios limites. Nesse sentido, o positivismo caracteriza-se por conceber um tipo de razão subjetiva, formal e instru- 
mental, cujo único critério de verdade é seu valor operativo, ou seja, seu papel na dominação do homem e da natureza. ${ }^{4}$

Se, nas ciências sociais, o positivismo não tem resistido aos seus críticos, sucumbindo diante de metodologias mais modernas e sofisticadas, em vários outros campos científicos, particularmente nas ciências naturais, médicas e biológicas, ele tem subsistido a ponto de ainda coincidir com o seu paradigma dominante.

O paradigma positivo-mecanicista dominante na medicina tende a não reconhecer o papel da sociedade, da cultura, da comunidade científica e da própria história na determinação de seu objeto de conhecimento e da maneira de abordá-lo. Pressupóe-se, assim, que o ato terapêutico possa ser explicado exclusivamente pela intervenção química ou física nas diferentes partes e estruturas do organismo humano no sentido de eliminar a doença, percebida, em grande medida, pela agressão monocausal externa de um agente patológico.

No entanto, dois fatores fundamentais têm recentemente contribuído para abalar os alicerces do paradigma positivo-mecanicista na área da saúde. O primeiro e principal deles diz respeito à deficiência desse paradigma em conceptualizar os problemas modernos da saúde humana. Estudos têm mostrado que condiçōes ambientais, socioeconômicas e culturais revelam-se com importância muito maior para a saúde de uma população do que condiçōes relativas à intervenção médica-biológica individual..$^{5}$ Existem também fortes indícios de que, a partir de um certo ponto, o aumento do nível de atividades médicas numa sociedade não corresponde a um aumento do nível de saúde da populaçăo. ${ }^{b}$

O segundo fator que tem contribuído para abalar o paradigma positivo-mecanicista diz respeito aos custos crescentes que esse tipo de medicina (inevitavelmente baseado em alta tecnologia) acarreta. Este fator torna-o incompativel com o ideal de democratização da oferta de serviços médicos, principalmente em países em desenvolvimento, com escassez crônica de recursos financeiros.

A postura marxista, ao focalizar o problema da saúde numa perspectiva dialética, critica o positivismo e o reduz a uma mera ideologia de classe. Contudo, embora este posicionamento tenha ampliado o horizonte do problema saúde e doença, a sua prática científica mostra algumas fraquezas e limitações. Ao indicá-las, pretendemos sugerir um caminho que exerceu influência no desenho teórico deste trabalho.

4 Ver a respeito, Luz, M. T. Natural, racional, social - razāo médica e racionalidade cientifica-moderna. Rio de Janeiro: Campus, 1988.

5 MacKfOWN, T. The role of Medicine: dream, mirage or nemesis. London: The Nuffield Provincial Hospitals Trust, 1979.

6 EHRENRECH, J. Introduction. In: Review Press, 1978.

(Ed.) The cultural crisis of Modern Medicine. New York: Monthly POWLE, J. On the limitations of Modern Medicine. In: MECHANIC, D. (Ed.) Readings in medical sociology.. pp.18-45, The Free Press, New York: 1980. 
Embora exista um marxismo mais aberto que mostra maior flexibilidade conceptual, permitindo, com isso, uma abordagem mais fértil do assunto, a predominância de um marxismo fechado e "ideologizado" tem prejudicado o desenvolvimento desta área de estudos. De um modo geral, esse tipo de marxismo tem se preocupado com a problemática da medicina e da saúde apenas com o intuito de reduzi-las à condição de expressão secundária de componentes estruturais mais amplos e profundos da sociedade.

De acordo com esta perspectiva, se a medicina científica prevaleceu historicamente sobre outras formas alternativas, foi porque ela seria mais funcional ao sistema capitalista dominante. Este, é importante lembrar, significa o ponto mais alto atingido pela humanidade antes de entrar em crise e ser superado pelo socialismo. Da mesma forma, se o investimento em medicina curativa mostra-se maior do que em medicina preventiva, seria porque na primeira o lucro é maior e sua manifestação mais conforme ao ethos individualista do sistema capitalista dominante. Nessa visão, a medicina curativa é percebida como resultante de uma forma de organização irracional onde predomina uma visão individualista do lucro. Esse sistema entraria em colisão com as necessidades coletivas da população, as quais somente um Estado centralizado e uma economia socialista planificada poderiam satisfazer.

No entanto, há dúvidas se realmente este argumento teria condições de resistir a uma investigação mais apurada. É, por exemplo, difícil sustentar porque o capitalismo haveria de beneficiar a medicina curativa ao invés da preventiva, uma vez que esta última pode ser, em várias circunstâncias, um excelente investimento econômico. A expansão do comércio, a crescente coordenação das atividades econômicas e as necessidades cada vez mais complexas das grandes corporações criaram, de fato, uma demanda para a Saúde Pública que o capitalismo foi capaz de satisfazer justamente onde ele se manifesta com maior vigor.?

É um fato incontestável, no entanto, que a medicina preventiva representa um paradigma que se opōe ao da medicina curativa na medida em que a proposta de procurar doenças em determinantes sociais mais amplos e saúde no controle ambiental e na educação comunitária contrapõe-se ao paradigma positivo-mecanicista que toma como universo de saúde e doença o corpo humano considerado individualmente. ${ }^{8} \mathrm{O}$ que parece simplista e artificial, no entanto, é atrelar automaticamente, sem respeito ao contexto e às condições históricas, um desses paradigmas a um determinado modo de produção.

Este caso mostra muito bem que uma ótica teórica pode, em certos contextos, obscurecer mais do que esclarecer um determinado aspecto da realidade. Isso significa que confiar irrestritamente numa teoria pode ser bastante perigoso, na me-

7 StaRr, P. The social transformation of american medicine. New York: Basic Books, 1982.

8 AroucA, A. S. S. O dilema preventivista - contribuição para a compreensão e crítica da Medicina Preventiva. Campinas, 1975. Tese de Doutoramento. FCM-UnKCAMP. 
dida em que essa atitude concorre para que ela deixe de ser um meio ou um instrumento de apreensāo da realidade e adquira vida própria.

Um outro aspecto crucial da crítica ao marxismo, na área da medicina e saúde, diz respeito à desconsideração pela noção de cultura e por qualquer tentativa de implementar uma medicina com um caráter mais social e humano como, por exemplo, a declaração de Alma-Ata, observada como sendo apenas uma máscara ideológica imposta pela burguesia para pretender manter o status quo e confundir a luta revolucionária. ${ }^{9}$ É evidente que esta concepção rígida e inflexível da teoria marxista não permite perceber a cultura como uma manifestação social que organiza o comportamento humano em vários níveis de realidade, inclusive o produtivo.

A antropologia social e cultural tem se encarregado de mostrar que a dimensão cultural mostra uma esfera de abrangência muito maior do que o sentido marxista de ideologia. ${ }^{10}$ A sua configuração não se adapta, de modo algum, ao que Marx entendia por superestrutura econômica e social. Em realidade, como muito bem demonstrou Worsley, ${ }^{11}$ o espaço compreendido pelo termo cultura ocorre, principalmente, no âmbito da infra-estrutura, compondo com as forças produtivas e os meios de produção um todo indivisível.

Por conseguinte, sustentamos o ponto de que aspectos culturais influenciam ou mesmo determinam o que e como produzir no momento mesmo da produção e não numa esfera metafísica ou ideológica da realidade. Sem aceitar esse aspecto, o marxismo corre o risco de conviver com um viés evolucionista unilinear e etnocêntrico, onde o caráter mecânico e técnico da produção, despojado de qualquer simbolismo, propelido por uma vaga e obscura noção de progresso, agiria como o motor da história.

O autor marxista que mais valorizou a cultura como agente transformador ou mantenedor da sociedade foi Cramsci, que compreendeu muito bem que sem uma transformação cultural, por mais que se desenvolvam as forças produtivas, não haverá possibilidade de revolução. Daí a ênfase que a sua obra atribui ao Partido e aos intelectuais na transformação de uma sociedade. A sua grande virtude é, sem dúvida, descartar completamente a possibilidade de evolução social através de forças produtivas mecânicas ou abstratas que se desenvolvem automaticamente.

Nesse sentido, sustentamos o ponto de que a dimensão cultural, principalmente a encontrada num setor importante como a prestaçăo de serviços de saúde, contribui decisivamente tanto para a manutenção como para a transformação da so-

9 Navarro, V. A critique of the ideological and political position of the Brandt Report and Alma Ata Declaration. In: Int. Jo. Med. Serv., 14: 159-72, 1984

10 SaHLins, M. Culture and practical reason. Chicago: The Un. of Chicago Press, 1976.

11 WORSLEY, P. M. Marxism and Culture: the missing concept. In: Occasional Paper, n. 4., Department of Sociology, University of Manchester, 1982. 
ciedade. Esta postura não diminui a importância do Estado e da relação de classes; ela apenas introduz um outro aspecto não menos importante da realidade social.

Talvez a principal virtude dessa dimensão seja estimular a pesquisa de campo. Ao invés de analisar uma determinada realidade, reduzindo-a a um epifenômeno de causas maiores como, por exemplo, a estrutura de classes ou a organização do Estado, ela procura, sem excluir a influência desses fatores mais abrangentes, concentrar-se no que a realidade estudada tem de específico. Essa atitude permite, ainda, procurar e encontrar, nessa mesma realidade, as condições que contribuem para sustentar o seu relacionamento com os fatores socioeconômicos, políticos e culturais mais abrangentes. $O$ método antropológico de análise qualitativa de pequena escala absorveu muito bem esse tipo de enfoque e, por isso, pode oferecer uma contribuição significativa para esse campo de estudo.

O método qualitativo adotado neste livro traz uma abordagem compreensiva que percebe o ator social como um agente que interpreta o mundo à sua volta com uma atitude que contém intenções e, portanto, projetos de ação. ${ }^{12}$ Nesta abordagem, a pesquisa não pode ficar prisioneira de hipóteses a-priorísticas, uma vez que a compreensão do problema resulta de um processo indutivo, que vai se definindo e delimitando na exploração do contexto social onde se realiza a pesquisa.

É um pressuposto fundamental da pesquisa que os sujeitos a serem entrevistados têm representações, embora incompletas, relativamente coerentes em relação ao universo vivido e experimentado. Trata-se de um conhecimento prático, de senso comum, que forma uma concepção de vida e orienta as açōes individuais. Como sujeitos da pesquisa, identificam e analisam os seus problemas e propóem intervenções mais eficazes na realidade. $O$ conjunto dessas representações, compreendendo consenso e discórdia a respeito de vários tópicos relativos ao universo vivido e experimentado, deve oferecer, em seu conjunto, uma compreensão mais rica de uma realidade cuja natureza assemelha-se mais a um caleidoscópio do que a um tecido estruturado rígido, impermeável a contradiçōes e mudanças.

Configurar a abordagem das representações sociais sob uma única interpretação teórica significa, necessariamente, dimensioná-las a partir de aspectos limitados que reduzem a sua complexidade e, em conseqüência, as empobrecem. Como muito bem nos lembra Alves \& Souza, ${ }^{13}$ a ambição de chegar a generalizações científicas expressas nas tentativas de resumir as açōes sociais, culturais e psíquicas a uma "geometria do vivido" ou a uma "gramática das ações", além de limitadora, é ilusória enquanto pretende descrever completamente um fenômeno deste tipo.

Ao invés de usar os fatos para confirmar uma determinada teoria, o método adotado neste livro, pelo contrário, utiliza-se de várias abordagens teóricas comc

12 SHutz, A. Collected Papers t: the problem of social reality. The Hague. Martinus Nijhoff, 1973.

13 ALvEs, P. C. \& SOUZA, I. M. Escolha e avaliaçăo de tratamento para problemas de saúde: o itinerário terapêutico. Texto apresentado no XVIII Encontro Anual da ANPOCS, 1994. (Mimeo.). 
instrumentos que realçam alguns pontos relevantes da realidade. Esta postura tem em Weber ${ }^{14}$ e, mais modernamente, na escola de sociologia fenomenológica ${ }^{15}$ as bases teóricas da teoria da representação social.

Levando em conta esta postura, o objetivo deste estudo pretende descer à microssubjetividade da experiência de saúde e doença, procurando, ao mesmo tempo, remetê-la a um nível sociológico e cultural mais amplo. ${ }^{16}$ Trata-se de apreender o aspecto exterior do objeto e seu relacionamento com esferas sociais mais amplas e, ao mesmo tempo, compreender o sentido interior, subjetivo, presente nas atitudes e na ação de sujeitos sociais que se encarregam de promover um determinado fato social. Como diz Bodstein ${ }^{17}$ a respeito, "o que se coloca como central na discussão sociológica hoje segue, em muito, a tradição weberiana de resgatar a explicação dos processos sociais pela dupla via: a partir do aspecto exterior, para além da intenção dos agentes sociais, sem com isso abandonar a dimensão da participação humana na formação e transformação das relaçōes e instituiçōes sociais".

O contexto e o momento da pesquisa mostraram-se bastante favoráveis à investigação. A reforma administrativa e a municipalização dos serviços de saúde, com o processo de implementação do Sistema Único de Saúde (SUS) então em curso, implicam necessariamente um momento de transição que pressupõe instabilidade institucional. Nesta condição, o universo vivido e representado perde a sua segurança sustentada pela tradição para se colocar como objeto fragmentado, cujas partes se oferecem às várias tentativas de reconstrução tanto no plano concreto quanto simbólico.

Situações como esta são consideradas ideais para a análise de valores, que em situação estável permanecem adormecidos nas profundezas da cultura, mas que, em situação de transição, emergem como um problema importante vivido e manipulado pelos indivíduos envolvidos. Numa situação de transição, os valores perdem a sua condição de absolutos e a realidade passa a ser construída, interpretada, manipulada, destruída e reconstruída, tendo como matéria prima o confronto de valores múltiplos, provenientes da situação vivida individual ou coletivamente pelo ator social. Deste modo, princípios culturais que normalmente não vêm à tona tornam-se explícitos e aparentes ao investigador. ${ }^{18}$

14 WEBER, M. A objetividade do conhecimento nas ciências e na política social. Lisboa: Ed. Lisboa Ltda., 1974.

Weber, M. A ética protestante e o espírito do Capitalismo. São Paulo: Pioneira, 1985.

15 SCHUTZ, A. Op. cit., 1973.

BerGer, P. \& LuCKMANN, T. The social construction of reality. Harmondsworth: Penguin, 1979.

16 SPINK, M. J. Desvendando as teorias implícitas: uma metodologia de análise das representaçōes sociais. In: Jovchelovitch, S. \& Guareschi, P. (Orgs.) Textos em Representaçōes Sociais, Petrópolis: Vozes, 1994.

17 Boosteln, R. C. A. Ciências Sociais e Saúde Coletiva: novas questōes, novas abordagens. In: Cad. Saúde Públ., 8(2): 140-149, Rio de Janeiro, 1992.

18 Gluckman, M. Op. cit., 1966.

Turner, V. W. Op. cit., 1960. 


\section{UM POUCO DE HISTÓRIA DA HANSENÍASE}

\section{UMA BREVE HISTÓRIA DA SAÚDE PÚBLICA NO BRASIL}

Antes de concentrar o foco na questão da hanseníase propriamente dita, é interessante ampliar um pouco o horizonte e introduzir um panorama histórico geral da Saúde Pública no Brasil.

A história da Saúde Pública no Brasil inicia-se no começo do século com a intervenção do Estado no processo de saneamento dos centros urbanos mais desenvolvidos, principalmente os portos, e o controle das doenças endêmicas que assolavam essas áreas. Oswaldo Cruz, no Rio de Janeiro, e Emílio Ribas, em Săo Paulo, deram início a este tipo de intervençăo que visava contribuir para a formaçāo de uma nação forte, com a erradicação das doenças endêmicas e infecciosas, entre elas a hanseníase.

Tanto Ribas como Cruz, formados na "Escola Pasteuriana", tinham como meta superar uma perspectiva não científica (a teoria miasmática) a partir da introdução da teoria bacteriológica, considerada mais adequada para organizar a intervenção no campo da saúde. Nesta linha, eles investiram numa ótica tecnológica, que via a saúde e a doença como um processo coletivo, resultado da agressão externa que o corpo biológico (fisiologicamente harmônico) sofria de um meio social/natural insalubre. Os seus objetivos eram a descoberta e isolamento de indivíduos doentes contagiantes, o saneamento do meio, a destruição dos vetores biológicos e a proteção dos sadios. Para instrumentalizar as ações de saúde, adotavam a bacteriologia e a engenharia sanitária. Secundariamente, utilizavam a medicina, entendida como muito limitada e pouco eficaz.

$O$ conjunto destas questôes era articulada num modelo assistencial público, que tinha na campanha e na polícia sanitária seus meios principais de efetivação. Neste período, organizaram-se leis, códigos e decretos que deram vida à política de saúde. Organizaram-se também institutos de pesquisa, laboratórios e serviços sanitários que se constituíram nos braços auxiliares das campanhas e das polícias sanitárias. Via de regra, os pensadores da política de saúde eram funcio- 
nários públicos e como tal compartilhavam das perspectivas que os grupos oligárquicos adotavam para as questōes sociais, tendo em vista servir ao processo agroexportador e legitimar o Estado.

A análise dos indicadores de saúde, em termos de mortalidade proporcional por causa, mostrou, no final da década de 1910, uma significativa queda da participação das consideradas doenças pestilenciais no total de mortes em São Paulo. ${ }^{1}$ Isto mostra que, em termos de eficácia de uma dada política social setorial, pelos estados, o modelo tecno-assistencial teve resultados positivos.

Desde 1910, com a Liga do Saneamento, já se buscava no Brasil uma ação social que saneasse a zona rural a fim de constituir um povo saudável, racialmente forte, permitindo, ao mesmo tempo, a ocupação do interior do País. Este movimento tinha, em Belisário Pena e Artur Neiva, dois dos seus mais significativos representantes. A campanha sanitária nacional pelas áreas rurais era considerada um instrumento vital para a integração nacional. Ao mesmo tempo, esta corrente caracterizou-se por criticar o excessivo urbanismo e regionalismo da política de saúde então vigente.

Novas idéias foram se organizando no interior deste modelo tendo em vista novos problemas com que a Saúde Pública se deparava, tais como a saúde de crianças e de trabalhadores urbanos, entre outros. Estas idéias desembocaram, na década de 1910, na formação de um movimento na Saúde Pública que ficou conhecido como "médico-sanitário", movimento este influenciado pela escola norte americana de saúde pública, que tinha em Baltimore seu núcleo mais ativo, através da associação entre a Fundação Rockefeller e a John Hopkins University.

No decorrer da década de 20, a corrente médico-sanitária tornou-se hegemônica, organizando-se principalmente nos grandes centros urbanos, como Rio de Janeiro, São Paulo, Belo Horizonte, Recife, entre outros. Dois núcleos foram especialmente ativos, o paulista influenciado por Paula Souza e Borges Vieira e o dos "jovens turcos", sanitaristas vinculados ao Departamento Nacional de Saúde Pública no Rio de Janeiro, que defendiam a especialidade na carreira médica na área de Saúde Pública e o trabalho integral nas instituições estatais. ${ }^{2}$

A base deste modelo pressupunha que o processo saúde-doença fosse um fenômeno coletivo - portanto, uma questão de saúde pública, mas determinado, em última instância, pelo nível individual. Para expressar esta idéia, utilizou-se o conceito de "consciência sanitária", que passou a ser entendido como o "canal" que permitia compreender como o meio insalubre atingia os indivíduos.

1 Merhy, E. E. A Saúde Pública como politica - um estudo de formuladores de politicas. Sāo Paulo: Hucitec, 1991. Esta obra dá suporte ao aspecto histórico desenvolvido na parte inicial deste capítulo.

2 Estes núcleos chegaram a organizar cinco congressos durante a década de 20 - os Congressos Brasilejros de Higiene - e tiveram tal influência no desenvolvimento da política de saúde no Brasil que sua presença se fez marcante até a reforma administrativa da década de 60/70 no interior da Secretaria de Saúde do Estado de São Paulo. 
A medicina e a Saúde Pública eram entendidas, neste esquema, como campos distintos, aquela para curar através da clínica, patologia e terapêutica, e esta para prevenir doenças, prolongar e promover saúde através da higiene e educação sanitária. O setor privado passou a ser entendido sob o ângulo "caritativo", de assistência social, que deveria ser controlado pelo serviço público. Não havia qualquer conflito com a organização liberal, predominante no período.

O modelo tecno-assistencial desta proposta centrou-se na construção de serviços permanentes de saúde pública - os centros e os postos de saúde, de modo regionalizado, de caráter público e comandados por especialistas, os sanitaristas, em tempo integral. Estes serviços eram institucionalmente vinculados às coordenaçōes técnicas mais centralizadas, que respeitavam os princípios da administração "científica".

Durante a fase de transição, entre 1930 e 1937, a Saúde Pública praticamente reduziu-se à atuação campanhista pelo conjunto do País, como se perseguisse a tomada de posse do espaço geográfico nacional. Esta conjuntura mostrou grande influência da "Liga de Saneamento", com o favorecimento de ações verticais permanentes baseadas nos projetos bacteriológicos e médico-sanitários. Foi um período que permitiu a expansão das questões sociais da previdência social e que viabilizou a construção dos serviços médicos previdenciários, abrindo um outro setor socialmente significativo no conjunto das açōes de saúde, no campo das políticas sociais.

Os "jovens turcos" foram marcando passagem pelas instituiçóes na luta por uma reforma que levasse à criação de organismos técnicos, de caráter nacional e centralizados normativamente. Eles influenciaram, assim, as reformas federais de 1920 e 1937 que permitiram a criação dos Departamentos Nacionais de combate a problemas específicos como a hanseníase, a malária, a febre amarela e a saúde de crianças.

$\mathrm{Na}$ década de 40 , diante dos problemas colocados pela situação da Segunda Guerra Mundial e das relações do governo brasileiro com o americano, os jovens turcos tiveram a oportunidade de organizar um serviço que permitisse a ocupação de regiōes importantes para a produção de borracha e minérios e implementaram a Fundação do Serviço Especial de Saúde Pública (Fundação SESP). À esta experiência, seguiu-se a criação, em 1953, do Ministério da Saúde e, em 1956, do Departamento de Endemias Rurais, que herdou um conjunto de projetos realizados nos departamentos verticalizados específicos, como o da malária, existente desde 1939.

No Estado de São Paulo, a exemplo do que ocorria com outros estados, a Fundação SESP influenciou a constituição da Secretaria Estadual de Saúde, em 1948, e a reforma da organização dos serviços de saúde no estado, em 1968.

No pós-guerra, sem alterar as estratégias básicas da corrente médico-sanitária, novos elementos foram sendo incorporados como, por exemplo, o uso da medicina 
clínica pela Saúde Pública, que encontrava suporte teórico na concepção de Leavell \& Clarck, ${ }^{3}$ que por sua vez preconizavam a união do conjunto das açōes de saúde num esforço comum de prevenção e cura. Esta concepção permitiu que as açōes de saúde se tornassem parte de uma atividade globalmente planejada.

Tomando como ponto de reflexão a falência das perspectivas "campanhistas" e "americanas", Mario Magalhães introduziu, na década de 50, a discussão do desenvolvimentismo, da integração das açōes, do planejamento em saúde, e da mercantilização das ações de saúde, numa perspectiva que supunha a superação das bases capitalistas de organização da sociedade brasileira.

A idéia mais intensamente propagada neste período é que a doença e a miséria não seriam controladas com maiores gastos em serviços de saúde, mas com o desenvolvimento econômico que levasse à maior independência da sociedade a partir da incorporação de novas tecnologias e maior controle sobre a natureza. Propunhase um padrão tecnológico mais racional, de menor custo, integrado em seus vários campos de atuação e sem influência das leis do comércio. Rompia-se com a dicotomia entre assistência médica e saúde pública, subordinando aquela à lógica desta.

A proposta de municipalização dos serviços de saúde defendida nas Conferências de Saúde do período pretendia uma política econômica que promovesse um desenvolvimento distributivista. Quanto à política de saúde, deveriam ser implantados serviços permanentes (contendo açōes médicas e sanitárias), municipalizados e controlados pelo Estado segundo uma hierarquia de complexidade tecnológica. A ação federal deveria ocorrer no sentido de normatizar as ações, racionalizar as atividades e ajudar os municípios que ainda não tivessem condiçōes de organizar seus próprios serviços.

Pela primeira vez apareceu no País a discussão de um modelo tecno-assistencial baseado na integração das ações coletivas e individuais de saúde, cujo ponto de apoio seria constituído a partir de senviços básicos de saúde permanentes, elaborados de acordo com um planejamento governamental. Pela primeira vez também levantou-se a questão da organização dos serviços médicos privados, ampliando o conjunto de forças que se colocavam na arena política criada no campo da política social de saúde.

A derrota destas propostas em 1964 abriu um outro capítulo que vingou na estruturação de um modelo centrado na assistência médica comercializada, que passava pelo setor previdenciário, sendo a Saúde Pública reduzida a um braço auxiliar. Em realidade, promoveu-se uma completa separação entre o campo da assistência médica e o da saúde pública, com maciços investimentos no primeiro e o sucateamento do segundo. Neste novo contexto, implementou-se um projeto privatizante e medicalizante. Somente em algumas regiōes renasceram experiências no campo da saúde pública que merecem alguma atenção, como o "campanhismo" 
em nivel federal e as ações médico-sanitárias em alguns estados, principalmente o de São Paulo, com o Secretário Leser, em 1968 e 1974.

O período autoritário-militar caracterizou-se por uma grande centralização política, financeira e operacional de todo o sistema de saúde, através de repasse de verbas do setor público ao privado. Esta ampliação do poder de intervenção estatal permitiu um enorme crescimento do setor privado, provedor direto ou indireto de equipamentos e de serviços médicos, propiciando a mercantilizaçăo e o empresariamento da medicina numa escala nunca antes atingida. $O$ crescimento do setor saúde engendrado por este sistema foi, no entanto, descontrolado, desconsiderando os problemas coletivos e gerando grande desperdício de recursos.

Seguindo recomendação da Organização Pan-americana da Saúde, as maiores universidades brasileiras criaram, nesta época, os Departamentos de Medicina Preventiva e Social que, principalmente através do Centro Brasileiro de Estudos da Saúde (CEBES), desenvolveram um pensamento crítico e propostas alternativas sobre medicina e o modelo assistencial então vigentes. De um modo geral, este período caracterizou-se na área da saúde por um repensar de todo o sistema, tendo em vista o propósito de se estabelecer uma reforma sanitária que, adequada aos limites financeiros impostos pela crise econômica, efetivamente pudesse oferecer melhores condiçōes de saúde à maioria da populaçăo.

Em 1974, o Governo federal reorganizou a estrutura institucional do Ministério da Previdência e Assistência Social, dando maior centralização de comando, aparando duplicações institucionais e funcionais, e viabilizando um maior controle sobre sua estrutura orçamentária e padrão de gastos. Isto, porém, não se fez acompanhar de medidas que alterassem substancialmente o modelo privado prestador de serviços e que tocassem no chamado complexo médico-industrial. Ao contrário, a busca de extensão com baixo custo desembocou na consolidação de projetos como o da Pronta Ação no interior da assistência médica previdenciária que ampliaram a base financeira disponivel para o setor privado.

A instituição do Sistema Nacional de Saúde, em 1975, abriu efetivamente um novo espaço de atuação a partir da assistência médica individual e de medidas de alcance coletivo voltadas para as populaçōes de baixa renda. Em 1976, a Secretaria Estadual de Saúde de São Paulo consolidou a formação de uma rede estadual/ municipal de Centros de Saúde estimulando vários municípios a começarem a construir a sua própria rede de serviços.

A partir de 1977, quando se estendeu o atendimento de urgência a qualquer indivíduo, previdenciário ou năo, os chamados "estouros" orçamentários no sistema previdenciário passaram a ocorrer com maior freqüência, acentuando a urgência de se imprimir uma maior racionalidade ao sistema de saúde. Vários planos provenientes do Governo federal (PREV-SAÚDE, CONASP) foram desenvolvidos neste período, propondo a descentralização do sistema de assistência médica através da criação de uma única "porta de entrada", integrando numa rede básica de senviços públicos de saúde a capa- 
cidade instalada já existente no INAMPS, nos estados e nos municípios, entrando a rede privada apenas onde não existiam unidades estatais.

A municipalização dos senviços de saúde passou a ser entendida como o único meio que permitiria um controle democrático pela comunidade, em oposição à excessiva centralização do modelo anterior. Esperava-se que ela estimulasse o desenvolvimento de uma medicina mais holística, que gravitasse em torno dos verdadeiros problemas de saúde de uma comunidade, além de prover uma melhor organização do sistema, tornando o serviço de saúde menos oneroso. Previa-se também um maior controle sobre o setor privado (tanto conveniado, quanto contratado) e um maior investimento na rede pública.

Este processo abriu a possibilidade de se vivenciar modelos tecnológicos e assistenciais alternativos baseados na medicina comunitária que, embora marcados pela lógica de extensão de cobertura e pelo baixo custo, foram experimentados com algum sucesso no interior das instituições públicas federais, estaduais e municipais. ${ }^{4}$

$O$ aprofundamento da crise econômico-financeira da Previdência Social promoveu um caráter menos pontual e mais definitivo às reformas, o que efetivamente ocorreu com as Açōes Integradas de Saúde (AIS) em 1982, que produziu um deslocamento relativo do dinheiro da Previdência para o setor público prestador de serviços de saúde, na esfera estadual e municipal. Este processo acentuou-se nas perspectivas que a "Nova República" trouxe para a arena política do setor, que foram expressas pela VIII Conferência Nacional de Saúde, pela estruturação do SUDS e pelo texto constitucional, aprovado pela Assembléia Nacional Constituinte, que levou à formação do SUS. Voltaremos a focalizar o SUS em tópico posterior neste mesmo capítulo.

\section{UMA BREVE HISTÓRIA DA HANSENÍASE}

A hanseníase, amplamente conhecida pela designação de "lepra", é uma doença muito antiga, mencionada por Hipócrates, mas que encontra na Bíblia, nos capítulos 13 e 14 do Levítico, a sua conotação repugnante e terrível. Esta condição de impureza e, portanto, de abominação, trouxe uma carga de preconceito que, juntamente com outras abominaçōes mencionadas pelo Levítico, foram muito bem analisadas por Mary Douglas. ${ }^{5}$ É no interior deste contexto que se encontram, por exemplo, as interpretações de que a lepra foi introduzida na Europa pelos Hebreus após a diáspora. ${ }^{6}$

4 Somarriba, M. M. G. Community Health and Class Society: the health programm of norte de Minas, Brazil. Ph.D. Thesis, Sussex: University of Sussex, 1978.

5 Doucias, M. Purity and Danger. Harmondsworth: Penguin Books, 1966.

6 Souzı Araújo, H. C. História da Lepra no Brasil. Rio de Janeiro: Departamento de Imprensa Nacional. 1956. 
É evidente que grande parte do estigma gerado por esta doença deve-se muito mais ao preconceito do que à condição objetiva da doença, uma vez que a grande maioria dos indivíduos, ao serem contaminados, oferecem resistência imunológica ao Mycobacterium leprae, o agente causador da doença. Waxler ${ }^{7}$ desenvolve esta tese, mostrando várias situações culturais com atitudes positiva ou negativamente carregadas em relação ao estigma na manifestação da hanseníase.

$\mathrm{Na}$ Idade Média, a hanseníase manteve alta prevalência na Europa e no Oriente Médio. O Concílio de Lyon ocorrido no ano de 585 estabeleceu o isolamento do doente da população sadia. Em alguns locais, esta medida foi bastante rigorosa e incluíam a realizaçăo de um ofício religioso em intenção do doente, semeIhante ao ofício dos mortos, após o qual ele era excluído da comunidade, passando a residir em locais especialmente reservados para esse fim. $O$ doente era ainda obrigado a usar vestimentas características que o identificavam como tal e fazer soar uma sineta ou matraca para avisar os sadios de sua aproximaçăo. ${ }^{8}$

A partir do século XII, surgiram as primeiras ordens religiosas dedicadas a prestar cuidados aos doentes de hanseníase, com a criação de asilos que chegaram a cerca de dezenove mil no continente europeu. ${ }^{9} \mathrm{O}$ declínio desta doença na Europa foi gradual, tendo se iniciado a partir do século XVII. Por volta de 1870 , a doença já havia praticamente desaparecido em quase todos os países da Europa e a causa mais provável deste desaparecimento foi a melhoria das condiçóes socioeconômicas. ${ }^{\text {to }}$

Simultaneamente ao desaparecimento na Europa, a endemia persistia na Ásia e África, tendo sido introduzida no Novo Mundo a partir das conquistas espanholas e portuguesas e da importação de escravos africanos. Não há qualquer evidência que possa mostrar que a população indígena no continente padecia deste mal. No Brasil, os primeiros casos foram notificados em 1600, na cidade do Rio de Janeiro. As primeiras iniciativas do Governo Colonial só foram tomadas dois séculos depois, com a regulamentação do combate à doença, por ordem de D. João V. Entretanto, as ações de controle limitaram-se à construção de leprosários e a uma assistência precária aos doentes.

Em fins do século XIX e começo do século XX, a hanseníase passou a ser alvo de maior atenção, principalmente na cidade do Rio de Janeiro e em São Paulo. Várias tentativas de tratamento da doença, realizadas principalmente no hospital, com

7 WAXLER, N. E. Learning to be a Leper: a case study in the social construction of illness. In: Misther, E. C. (Ed.). Social contexts of health, illness \& patient care. Cambridge University Press, 1981.

8 Ministério da Saúde. Secretaria Nacional de Programas Especiais em Saúde Divisāo Nacional de Dermatologia Sanitária. Controle da hanseniase: Uma proposta de integração ensino-serviço. Rio de Janeiro: OMS/Nutes, 1989.

9 Op. cit., 1989.

10 Ver, a respeito, MacKŁoWn, T. The role of medicine: dream, mirage or nemesis. London: The Nuffield Provincial Hospital Trust, 1976. 
uma população de incapacitados e pobres, ocorreram nesta época." Entre outras doenças infecciosas, a hanseníase serviu como um dos mais importantes pontos de referência para a grande polêmica sobre a unicausalidade ou multicausalidade das doenças em geral. A influência dos experimentos de Pasteur foi decisiva para que a idéia da unicausalidade, através de um agente patogênico externo (um microorganismo), fosse vitoriosa. Procurava-se nesta época um agente intermediário, um vetor, que explicasse o contágio da mesma forma que o mosquito da febre amarela.

Muitos experimentos foram realizados em pacientes, com o uso de várias drogas, causando-lhes, em geral, muito mais danos que benefícios. A maior parte dessas tentativas partia do pressuposto de que todas as manifestações da doença, então conhecida apenas como lepra, que antes se confundia com muitas outras patologias da pele, se unificaram a partir de um denominador comum: o bacilo específico da doença, denominado Mycobacterium leprae ( $M$. leprae). A cura passou a ser uma questão de encontrar uma substância que pudesse matar o bacilo. As tentativas foram preenchidas pela imaginação, muitas vezes delirante, de médicos obcecados com alguma forma de tratamento. Uma dessas tentativas foi a inoculação com o bacilo de outras doenças, como a erisipela; outra, a mordida de cobras venenosas. Num desses experimentos, o paciente foi submetido a uma mordida de cobra cascavel. Embora ele tivesse morrido em 24 horas, o relato demonstra algum entusiasmo com a possibilidade de cura ser obtida através deste meio, uma vez que houve depressão notável dos tubérculos. ${ }^{12}$

O óleo de chaulmoogra foi conhecido por muito tempo no Oriente como remédio para a lepra e introduzido na Europa em meados do século XIX, e no Brasil poucas décadas após, no Hospital dos Lázaros, no Rio de Janeiro. Não demorou muito para que esse medicamento passasse a ser visto como tão específico para a lepra como o salycilato para o reumatismo e a quinina para o paludismo. O tratamento consistia em uso interno e externo, provocando reaçōes fortes nos pacientes, tais como gastralgia, vômitos e diarréia. Apesar de ter sido universalmente aceito como benéfico ao tratamento, não há nenhum indício de que realmente ele possa ter sido eficaz. Outra forma de tratamento era a eletrocauterização das lesōes cutâneas. De um modo geral, os tratamentos disponíveis nesta época eram verdadeiras torturas para o paciente, além de totalmente inócuas para checar o desenvolvimento da doença.

Em 1874, o médico e botânico norueguês Armauer Hansen demonstrou pelo simples exame a fresco, nas chamadas células leprosas de Virchow, encontráveis nos nódulos cutâneos da doença, a presença dos bastonetes agentes da infecção. Com a introdução do conceito de microorganismo e de contágio, os hospitais passaram a

11 Souza Araújo, H. C. História da lepra no Brasil. Rio de Janeiro: Departamento de Imprensa Nacional, 1956.

12 Souza Araúfo, H. C. Op. cit., 1956. 
ser considerados inadequados para o tratamento da hanseníase e os doentes, mais do que em épocas anteriores, uma ameaça social. Nas primeiras décadas deste século tem início, no interior do processo de higienização da sociedade, a luta contra a hanseníase, através do confinamento compulsório dos doentes em leprosários. A noção de contágio foi reforçada pelo imperativo, pela primeira vez colocado, de se formar um povo, uma raça forte e sadia.

A primeira parte desta luta refere-se a desacreditar os que ainda advogavam o caráter hereditário e não contagioso da hanseníase. Sob o ponto de vista de que o doente passou a ser considerado como a única fonte de propagação da moléstia, para a profilaxia desta doença, passou a ser necessário o controle do doente. A idéia de confinar todos os leprosos numa ilha foi logo patrocinada por Oswaldo Cruz e outros médicos ilustres tais como os paulistas Ulysses Paranhos, Alberto Seabra e Adolpho Lindenberg, uma posição vitoriosa no VI Congresso Brasileiro de Medicina e Cirurgia, realizado em Săo Paulo em 1907. Este Congresso também advogava a necessidade de desinfecção domiciliar das cidades na luta contra todas as doenças infecciosas, numa suposição de que haveria um vetor intermediário no processo de contaminação.

Esta medida tinha como suporte a idéia de que o confinamento de indivíduos portadores de doenças infecciosas traria necessariamente a erradicaçăo da doença. Medidas semelhantes estavam sendo postas em prática pelo governo norte-americano em seu próprio território, principalmente em estados do sul do país, nas ithas do Havaí e nos territórios sob seu controle, como as Filipinas. Na Índia, país de alta endemicidade, esta forma de tratamento se impunha sob o patrocínio britânico.

No Brasil, Emílio Ribas, Oswaldo Cruz e Alfredo da Matta foram os principais nomes que, ao denunciar o descaso do combate à endemia pelas autoridades sanitárias, trouxeram o reconhecimento do problema e medidas legais para implementar o isolamento compulsório dos doentes. As açōes de controle de então priorizavam a construção de leprosários em todos os estados endêmicos, o censo e o tratamento pelo óleo de chaulmoogra.

Em 15 de setembro de 1920, com a criação do Departamento Nacional de Saúde Pública pelo Decreto $n^{2} 14$, foi instituída a Inspetoria de Profilaxia da Lepra e Doenças Venéreas. As seguintes medidas foram implementadas pela lei:

- notificação compulsória e levantamento do censo de leprosos;

- fundação de asilos-colônias, nos quais seriam confinados os leprosos pobres;

- isolamento domiciliar aos que se sujeitassem à vigilância médica e tivessem os recursos suficientes para a eficaz aplicação dos preceitos de higiene;

- vigilância sanitária dos comunicantes e suspeitos de lepra;

- isolamento pronto dos recém-nascidos, filhos de leprosos, para local convenientemente adaptado e onde seriam criados livres das fontes de contágio; 
- proibição da importação de casos de lepra do estrangeiro;

- notíficação de mudanças de residência de leprosos e de sua família;

- desinfecção pessoal dos doentes, dos seus cômodos, roupas e de todos os objetos de uso; as suas excreçöes deveriam ser recebidas em vasos cobertos contendo uma solução desinfetante e levadas ao esgoto;

- rigoroso asseio das casas ocupadas por doentes e de suas dependências:

- proibição ao doente de lepra de exercer profissōes ou atividades que pudessem ser perigosas à coletividade ou exercer qualquer profissão que o colocasse em contato direto com pessoas; como também ser ama-de-leite, freqüentar igrejas, teatros e casas de divertimentos ou lugares públicos como jardins e viajar em veículos sem o prévio consentimento da autoridade competente.

Os estados de São Paulo e do Rio de laneiro foram os que adotaram mais consistentemente essas diretrizes, com um número significativo de colonias e de doentes confinados. Em São Paulo, havia um hospital colônia central de Santo Ângelo e quatro outros regionais, além de asilos em vários dos municípios. As iniciativas partiam quase sempre da associação entre o estado, o município e as Santas Casas de Misericórdia. Alguns prefeitos destinavam uma percentagem significativa de verbas públicas para uso específico na profilaxia da lepra. O leprosário de Pirapitinguí, por exemplo, resultou da associaçāo entre as prefeituras de Campinas, Jundiaí e Sorocaba. Via de regra, o Governo do estado passava a destinar uma verba anual para iniciativas desse tipo. O leprosário-modelo de Santo Ângelo, próximo a Mogi das Cruzes, com capacidade para abrigar 800 doentes, foi construído por um consórcio entre o estado, a Santa Casa e donativos particulares. O trabalho de Ítalo Tronca mencionado anteriormente transmite muito bem, em fortes imagens de vídeo, o ambiente degradante e desumano desses asilos.

As dificuldades de implementação das medidas profiláticas da lepra foram consideráveis, tendo em vista, principalmente, a limitação de recursos e as características próprias da hanseníase, cujos sintomas podem ser facilmente camuflados por um longo período da manifestação da doença. Os pacientes, em geral, resistiam o quanto podiam e só aqueles cujos sinais eram muito evidentes sucumbiam às propostas médicas.

A década compreendida entre 1921 e 1930 via a solução do problema como uma questão muito mais difícil do que parecia na década anterior. As experiências de confinamento na Índia, no Havaí e, principalmente, nas Filipinas, fracassaram diante das medidas "draconianas" implementadas. O sistema adotado nas Filipinas era o de regime violento; os médicos, acompanhados de policiais, praticavam raids no interior da ilha para caçar os leprosos que encontravam, para depois confiná-los em alguma outra ilha do arquipélago. Um número superior a quinze mil doentes foram assim isolados num período de 19 anos. A mortandade entre eles foi da ordem de $60 \%$, neste período. 
Após 15 anos desse tipo de tentativa, percebia-se que a freqüência da hanseníase não se reduzia nos países que a implementaram. Em vista disso, medidas violentas foram pouco a pouco abolidas, adotando-se medidas mais brandas como o isolamento domiciliar, no caso do paciente provar competência de absorver medidas adequadas de higiene.

Na Academia Brasileira de Medicina, o problema da hanseníase foi empolgante naquela década, principalmente nas sessōes de 1926, com a polêmica entre Belisário Pena - que defendia iniciativas radicais, assentadas nas idéias e nas medidas que Oswaldo Cruz desenvolveu no começo do século - e Eduardo Rabello, defensor de providências muito mais brandas, onde o controle principal seria através do isolamento domiciliar.

A proposta de Eduardo Rabello foi vitoriosa porque já se tinha alguma experiência das dificuldades de implementar um confinamento absoluto. Os recursos necessários iriam muito além da vontade política dos governos e das possibilidades do País, sem que houvesse garantia alguma de sucesso, nem que fosse mobilizado todo o exército nacional para executar as medidas necessárias. É evidente também que nenhum estado haveria de querer ceder um município para tal fim, um fenômeno que efetivamente ocorreu nos Estados Unidos e que só foi solucionado após 10 anos de negociaçōes com o Estado de Louiziana, onde se estabeleceu um grande leprosário.

Um outro fator que contribuiu para promover medidas mais brandas no controle da hanseníase foi a diminuição considerável do impacto da idéia do contágio e desenvolvimento da doença. A idéia da predisposição genética, ridicularizada na década anterior, voltou a ser considerada como um fator importante no desenvolvimento da doença. $O$ não-desenvolvimento de uma cultura do bacilo da hanseníase em algum animal, por outro lado, impedia a produção de uma vacina e de um medicamento eficaz. Com isso, pacientes que estariam dispostos ao tratamento, se tivessem alguma perspectiva de cura, não se conformavam com um confinamento perpétuo.

O isolamento dos pacientes foi una iniciativa que não se revelou capaz de controlar a endemia e contribuiu muito para aumentar o medo e o estigma associados à doença. Falsos conceitos sobre a sua transmissibilidade ainda hoje promovem rejeição pela sociedade e até mesmo por profissionais da saúde. Promovendo o medo e mesmo o pânico, estimulando indivíduos a fugirem antes ou depois de serem denunciados à polícia sanitária, a busca ativa de casos revelou-se uma política pública que não trouxe resultados positivos.

$\mathrm{O}$ indivíduo era segregado de seu meio familiar, levado a uma colônia, proibido de desenvolver qualquer contato com qualquer indivíduo de fora e submetido a um tratamento médico doloroso e comprovadamente inútil. As visitas eram realizadas sob um controle estrito no qual se evitava o contato; a simples aproximação do visitante o obrigava a um processo de fumigação esterilizante. Os filhos de pa- 
cientes confinados eram imediatamente retirados do convívio com os pais e internados em orfanatos especiais. O rigor aplicado no confinamento no Estado de São Paulo foi em geral muito mais estrito do que em outros estados do Brasil.

Os asilos funcionavam a partir de parâmetros europeus e norte-americanos, ou seja, eram isolados da comunidade, recebiam desta ajuda e promoviam a sua própria vida social. As casas eram individuais ou coletivas, onde residiam dois ou mais pacientes. Os que se casavam procuravam ter a sua própria residência. Havia igreja, clubes, oficinas de móveis e de outros tipos de trabalho, beneficiadoras de café ou arroz, abatedoras de animais e outras instituições sociais e econômicas. Promoviam-se festas, bailes e atividades esportivas.

A partir dos anos 30, a Inspetoria da Profilaxia da Lepra perdeu a sua força após o período de regulamentações e definições de metas. Não houve sustentação política para as suas propostas e o serviço, sem atingir suas finalidades, burocratizouse como tantos outros criados com a melhor das intenções. As ações um pouco mais efetivas vieram dos estados economicamente mais ricos, com um reduzido apoio federal.

Após a segunda metade deste século, com a criação da Campanha Nacional do Controle da Hanseníase, ocorreu uma mudança fundamental na abordagem deste problema a partir do surgimento da sulfona, um antibiótico que não produz muitos efeitos colaterais, ao mesmo tempo em que permite a cura da doença, embora o tratamento seja quase sempre prolongado. Com a nova tecnologia, a erradicação da endemia passou a ser vista como um empreendimento que combinava a perspectiva da saúde pública com a clínica. O dermatologista sanitário, funcionário público em tempo integral, surgiu nesta época, com esta postura. Criou-se com isso, no Brasil, uma forte Escola de Lepra, que realizou pesquisas pioneiras nesta área médica.

Nem todos os doentes eram internados, mas a lógica da internação persistia porque havia hospitais especializados e grupos com interesses nítidos na manutenção desse esquema: os dermatologistas sanitários e os doentes. Nesta época, o doente havia recebido privilégio que o tornava uma espécie de funcionário público pelo simples fato de ser doente. Alguns dos hospitais especializados pagavam para cada um deles, além de casa e comida, um salário mensal.

O sistema hospitalar já não era de confinamento, de reclusão absoluta. Era um sistema misto, de colônia, com um hospital no centro e moradias ao redor. Uma vez entrando nesta colônia, o doente não conseguia mais sair. Mesmo que curado parasitológica e clinicamente, culturalmente ele não conseguia mais se reinserir na sociedade e continuava doente para sempre.

A partir da reconstrução do Ministério da Saúde, em 1974, o poder técnico foi colocado no comando como parte de um projeto autoritário. Foi nesta ocasião que surgiu, no interior da concepção da medicina preventiva e da medicina comunitária, importada da John Hopkins University, a figura do sanitarista moderno. Com ele surge uma nova lógica de extensão de cobertura (inclusive para os não doentes), 
de hierarquização de serviços de saúde e de interesse voltado à comunidade. Neste contexto, teve início a política de tratamento ambulatorial da hanseníase.

O Estado monopolista planificador assume a coordenação da reprodução social e se debruça sobre a sociedade como um todo. Pela primeira vez começa a se pensar em termos de custo-benefício das açōes de extensão do poder público, do sistema de saúde. O eixo da medicina preventiva nảo se encontra mais na racionalidade científica como no tempo dos "jovens turcos", mas na racionalidade gerencial. Os sanitaristas passaram a se formar não só como técnicos de saúde pública, mas como gerentes de unidades inscridas numa rede de serviços de saúde.

Neste período, o Brasil teve a iniciativa pioneira de substituir oficialmente o termo lepra por hanseníase. Essa medida, cujo propósito foi minimizar a importância do problema, tem contribuílo para diminuir o preconceito e o estigma que envolvem a doença. Trata-se, no entanto, de uma medicla parcial que, por si só, tem um alcance limitado se năo for acompanhada por campanhas educativas e por medidas de controle que exigem muito mais recursos financeiros do que têm sido disponíveis.

A partir da década de 80, a política de saúde voltou-se no sentido de realmente desativar os asilos e promover a integração do paciente à sua família. Este esforço, no entanto, deparou-se com uma dificuldade inesperada: a resistência dos doentes em deixar o asilo. Após um longo confinamento, muitos deles mostraram-se totalmente desadaptados ao convivio familiar e social e tiveram que continuar nos asilos, em processo de desativaçāo gradativa. Atualmente, ainda existem cerca de mil e quinhentos asilados no Estado de São Paulo, e há um projeto para concentrálos no asilo de Pirapitinguí.

A partir de 1985, com muito atraso, pôde o Ministério da Saúde tomar algumas iniciativas no sentido de adequar o programa da hanseníase com o recomendado pela Organização Mundial da Saúde. Os hospitais-colônia foram reestruturados e a poliquimioterapia (PQT), que consiste no acréscimo de dois outros antibióticos, iniciada em função da resistència do agente etiológico à sulfona.

Com a PQT, a lógica classificatória da doença e as formas de tratamento mudaram completamente. A questão de saber se a forma da doença era tuberculóide ou virchoviana passou a ser irrelevante, ponto este contestado pelos dermatologistas sanitários tradicionais. As unidades especializadas em hanseníase transformaram-se $\mathrm{cm}$ sobrevivências anacrônicas, tendo em vista que qualquer unidade e qualquer médico deveria ter condiçōes de lidar com a hanseníase. Este ponto, embora amplamente reconhecido pelos sanitaristas, ainda permanece por se fazer, uma vez que o tratamento da hanseníase ainda se encontra confinado em unidades especializadas. A falta de treinamento e preparo dos médicos em diagnosticar e tratar esta moléstia é o principal obstáculo que impede a descentralização do tratamento da hanseníase pela rede pública de serviços de saúde. 


\section{A SITUAÇÃO EPIDEMIOLÓGICA DA HANSENÍASE NO BRASIL E EM CAMPINAS}

A hanseníase é prevalente no Brasil, e constitui-se um sério problema de saúde em várias partes do mundo subdesenvolvido. A doença é definida como infectocontagiosa crônica, de longa duração. Produzida pelo Mycobacterium leprae (M. leprae), ao manifestar-se compromete a pele e, principalmente, o sistema nervoso periférico. Pode também comprometer os vasos, glândulas, órgãos internos, aparelho locomotor, boca, laringe, globo ocular, nariz e outros órgãos. As principais fontes de bactérias săo, provavelmente, as mucosas das vias aéreas superiores. Também são fonte de bacilos os hansenomas ulcerados, o leite materno, a urina e as fezes.

A hanseníase é transmitida de pessoa a pessoa, através do contato íntimo e prolongado com doentes das formas contagiantes (Virchoviana ou Dimorfa), sem tratamento. Sua transmissão está também fortemente ligada a fatores socioeconômicos, tais como: estado nutricional, a situação de higiene e, principalmente, a condição de moradia da população. A probabilidade de transmissão da doença é muito maior, por exemplo, num barraco de favela em que residem vários indivíduos, estando um deles infectado. Entretanto, um fato importante é que a maioria das pessoas não adoece mesmo convivendo durante muito tempo, na mesma casa, com doente contagiante sem tratamento. Há estudos imunológicos que indicam que cerca de $90 \%$ das pessoas têm defesa natural contra o M. leprae. ${ }^{1}$

Nesse contexto, o verdadeiro problema com que se depara qualquer programa de saúde pública que vise a erradicar a hanseníase não é, como em muitas outras doenças infecciosas, interceptar a cadeia de transmissão, principalmente se for considerado o fato de que grande parte da população brasileira está contaminada pelo $M$. leprae, embora não desenvolva a doença. O problema real seria interceptar

1 Talmares, S. \& Neves, R. G. Hanseníase. ISEA -, Instituto Superior de Estudos da Amazônia, 2. ed., 1989.

Organizaçāo Pan-americana da Saúde. Manual para o controle de lepra. 2. ed. Washington, D.C., 1989. 
a cadeia de recepção, que só poderia se realizar através da descoberta de uma vacina específica, o que ainda não ocorreu e nem deverá ocorrer tão cedo.

O modo de transmissão da hanseníase é, portanto, complexo, sendo necessária a interação de dois fatores: o grau de contagiosidade do infectante e o grau de receptividade do indivíduo exposto. Quando a contagiosidade é forte e a receptividade da pessoa exposta é alta, é possível uma transmissão rápida da doença, não sendo necessários nem uma exposição longa nem contatos íntimos. ${ }^{2}$

Nos indivíduos que adoecem, a infecção também se desenvolve de acordo com as características imunológicas do hospedeiro. Se estas forem mais competentes, produz-se uma forma localizada e não contagiosa da doença; do contrário, desenvolve-se uma forma generalizada e contagiosa. Entre esses extremos, encontramse as formas intermediárias, refletindo um largo espectro de variações de resistência. ${ }^{3}$ Estima-se que cerca de $10 \%$ das pessoas infectadas apresentam sinais da doença após um período de incubação, que leva em média de dois a sete anos.

A classificação da doença, atualmente adotada nos serviços públicos de saúde brasileiros, resultou do VI Congresso Internacional de Leprologia, realizado em Madri, em 1953. Neste Congresso, manteve-se a proposta do Congresso de Havana de 1948 , de classificar a doença segundo sua tendência de evoluir em direção a um de seus pólos, Virchoviano ou Tuberculóide. Nesta concepção, e de acordo com as diretrizes do Ministério da Saúde, ${ }^{4}$ a classificação da doença deve basear-se em quatro critérios: o clínico, o imunológico, o bacteriológico e o hispatológico, que permitem detectar quatro formas básicas de manifestação da hanseníase, quais sejam:

- Indeterminada (I) ou precoce: fase inicial da doença. Apresentam-se manchas hipocrônicas de limites imprecisos e áreas de hipestesia térmica seguidas de alterações de sensibilidade dolorosa e tátil. $O$ indivíduo pode permanecer na forma indeterminada durante muito tempo, antes de ocorrer a polarização para a forma tuberculóide ou virchoviana, o que dependerá do seu comportamento imunológico.

- Tuberculóide (T): pólo não contagioso, habitualmente estável, com bacterioscopia, em geral, negativa, lesōes bem delimitadas e freqüente acometimento nervoso.

- Virchoviana (V): pólo contagioso, com grande número de bacilos, apresentando lesões cutâneas difusas e acometimento sistêmico.

- Dimorfa (D): muito instável, com baciloscopia positiva ou negativa e manifestações cutâneas polimorfas.

2 Noussitou, F. M., Sansarricg, H., Walter, J. A lepra na criança. Associazione Italina "Amici di Raou! Follereau", 1981.

3 Rotberc, A. Noçōes de hanseniologia. Săo Paulo: Fundaçāo Paulista contra Hanseníase, 1979.

4 Ministério da Saúde. Secretaria Nacional de Progranıas Especiais em Saúde Divisão Nacional de Dermatologia Sanitária. Controle da hanseníase: Uma proposta de integração ensino-serviço. Rio de Janeiro: OMS/Nutfs, 1989. 
Para chegar a uma classificação da forma de hanseníase de que o paciente é portador, além da sintomatologia clínica e hispatológica, é de grande utilidade o teste de Mitsuda que, mesmo sem ser propriamente uma prova de diagnóstico, é útil na classificação de um paciente, uma vez realizado o diagnóstico. ${ }^{5} \mathrm{O}$ teste de Mitsuda baseia-se em uma reação imunológica do tipo celular de alta especificidade para o $M$. leprae, que permite a avaliação prognóstica para portadores de hanseníase. $O$ teste é negativo para a forma virchoviana, positivo na forma tuberculóide, enquanto nos portadores da forma indeterminada pode ser negativo (prognóstico evolutivo para o pólo Virchoviano), positivo (prognóstico evolutivo para o pólo Tuberculóide) ou ainda duvidoso.

Originalmente, o teste de Mitsuda foi desenvolvido com o objetivo de descobrir uma vacina, empreendimento que, infelizmente, nāo foi bem-sucedido. Contudo, observou-se que o teste servia para diferenciar os indivíduos que reagem dos que năo reagem à presença da micobactéria. $O$ teste é feito através da remoção de um pedaço da região lesada (hansenoma) de um paciente (ou de animais de laboratório), que é laboratorialmente macerado e preparado para ser inoculado em um outro paciente. Na forma tuberculóide, ou em indivíduos sãos, ocorre uma reação, um calombo no local (Mitsuda positivo); na forma virchoviana não há reação (Mitsuda negativo) que comprove a existência de uma deficiência imunológica do paciente.

O resultado do teste de Mitsuda é também utilizado para reagrupar os pacientes para a implantação dos novos esquemas terapêuticos (poliquimioterapia). Esse reagrupamento resultou em algumas readequações na nomenclatura. Nesse contexto, usam-se os termos multibacilares e paucibacilares. Os primeiros definemse pelos pacientes portadores da forma virchoviana, dimorfa e indeterminada, com Mitsuda negativo, enquanto os segundos definem-se pelos pacientes portadores da forma tuberculóide e indeterminada, com Mitsuda positivo. Estudos empreendidos pela Organização Pan-americana da Saúde ${ }^{6}$ mostram que as formas multibacilares têm grande responsabilidade epidemiológica na transmissăo da doença: enquanto as pessoas que têm contato intradomiciliar com pacientes paucibacilares estão duas vezes mais propensas a contrair a doença do que os sem contato, as pessoas com contato intradomiciliar com pacientes multibacilares correm um risco de 4 a 10 vezes maior.

Infelizmente, ainda hoje, a hanseníase está muito atrasada com relação aos avanços obtidos para a cura da tuberculose, que também utiliza a poliquimioterapia (PQT) - recentemente posta em prática diante da maior resistência do agente etiológico ao tratamento ministrado com a sulfona. No caso da tuberculose, o conhecimento está muito mais adiantado. Os antibióticos utilizados são específicos para cada caso e para cada situação, de acordo com a população bacilar e os locais em

5 Organizaçăo Pan-americana da Saúde. Op. cit., 1989.

6 Organização Pan-americana da Saúde. Op. cit., 1989. 
que se encontra: Já no caso da hanseníase, ainda não se desenvolveram antibióticos específicos.

É interessante notar que a tuberculose sempre apresentou um caráter que, apesar de trágico, não era estigmatizante. Era uma doença que afetava também os ricos, principalmente aqueles que, de acordo com a representação construída no século passado, viviam intensamente a vida, descuidando-se da saúde. Tratava-se, por isso, de uma doença que merecia ser dimensionada e revestida de atenção cultural e artística. A literatura e a ópera encarregaram-se de promover uma imagem romântica para a doença, enquanto a ciência procurou concentrar esforços no sentido de estudá-la e encontrar melhores formas terapêtuticas.

Já a hanseníase nunca encontrou qualquer representação cultural favorável. Trata-se de um mal que não afeta e nunca afetou de um modo significativo a sociedade dominante, como ocorre atualmente com a AIDS. Provavelmente por este motivo a doença desperta interesse ou compaixão apenas marginal. Mesmo atualmente, o estudo e a investigação nesta área ainda são isolados, e mesmo as faculdades de medicina dedicam uma atenção muito pequena a este problema.

Assim, a pesquisa com hanseníase até hoje não obteve uma técnica que permitisse a mais elementar cultura de célula, base fundamental para o desenvolvinento de uma vacina. Só em 1960 conseguiu-se inocular o bacilo em ratos. A forma da doença que se desenvolveu, no entanto, foi a paucibacilar tuberculóide e o rato curava-se espontaneamente depois de oito meses. Em 1972, conseguiu-se inocular o bacilo no tatu, que leva dois anos para desenvolver a doença. A duplicaçăo de material imunológico (DNA) da micobactéria da hanseníase é bem recente e um processo excessivamente caro. Essa técnica, empregada amplamente pela biologia molecular, permite um diagnóstico laboratorial precoce e é promissora no sentido de ensejar estudos mais avançados sobre a doença.

Uma vez que não se tem um teste confiável para se detectar a infecção pelo M. leprae, pouco se sabe tanto sobre o nível de infecçâo da população como sobre o mecanismo de transmissão. Em conseqüência da não detecção da infecção no indivíduo e porque o doente significa uma proporçâo ínfima entre os infectados, fica a impressão equivocada de que o indice populacional de infecção é pequeno. $O$ índice de transmissibilidade é, na verdade, muito grande, sendo baixa apenas a proporção de pessoas que adoecem após terem sido infectadas.

A hanseníase prevaleceu no norte da Europa até o século XIII e depois disso declinou gradativamente até a sua extinção. Fine $^{7}$ relata que aproximadamente $\mathbf{8 0 0}$ mil casos foram registrados na Noruega na segunda metade do século XIX e que $O$ último caso endêmico conhecido ocorreu em torno de 1950 . Há evidências de que o desaparecimento da hanseníase, juntamente com o desaparecimento de muitas outras doenças infecciosas na maior parte do continente europeu, tenha ocorrido

7 Fint, P. E. Leprosy, the epideniology of a slow baslcrium. Lpidemiologic Reviews, 4: 161-188, 1982. 
por causa da melhoria das condiçōes socioeconômicas e de vida em geral, particularmente no que se refere à alimentação, às condições sanitárias e ao controle populacional. ${ }^{8}$

O mesmo fenômeno não ocorreu na maioria dos países tropicais e subdesenvolvidos. A maior parcela dos indivíduos doentes, nessas regiōes, vive em condiçōes precárias de habitação, nutrição e higiene, o que dificulta o controle da epidemia. A Organização Mundial da Saúde estima que existam atualmente de 10 a 12 milhões de casos de portadores de hanseníase, praticamente todos eles concentrados no mundo subdesenvolvido.

O crescimento da endemia está também ligado a fatores tais como diagnóstico incompleto, despreparo dos profissionais da área da saúde nas ações assistenciais (tratamento dos doentes, controle e acompanhamento dos comunicantes) e educativas (trabalho de grupos, palestras, visitas domiciliares) visando a prevençăo da doença. Preconceitos dos profissionais da área da saúde também constituem barreira para o desenvolvimento de um programa no controle junto ao doente e seus comunicantes.

Convencionou-se que a hanseníase constitui um grande problema de saúde sempre que a prevalência da doença é maior que 1 caso em cada mil habitantes. Áreas com coeficientes inferiores a 0,2 casos por mil habitantes são consideradas de baixa endemicidade, enquanto coeficientes entre 0,2 e 1,0 por mil habitantes correspondem às áreas de média endemicidade. Numa região de alta endemicidade, o risco de se contrair a doença aumenta, em países e regiões subdesenvolvidos, diante da precária cobertura dos serviços de saúde, de pessoal técnico despreparado e não aderente às dificuldades e necessidades dos pacientes hansenianos e de sua família.

Em escala mundial, o número de casos registrados vem sofrendo um aumento constante nos últimos 20 anos: 2.831 .775 em 1966; 3.599 .949 em 1976; e 5.368.202 em 1985. O último número representa um aumento de $49 \%$ em relação à 1976 e $89,6 \%$ à 1966 . A prevalência de casos registrados aumentou respectivamente de 0,84 casos por mil habitantes, em 1966, para 0,88 em 1976 e 1,2 em 1985.

As regiōes de maior prevalência da doença localizam-se principalmente no continente africano, embora a Ásia e a América Latina também apresentem regiôes problemáticas. Na América Latina, cerca de 126 milhōes de pessoas ( $31 \%$ da população) vivem em áreas com taxa de prevalência superior a 1 por mil, o que é considerado alto, embora a endemia esteja declinando nesta regiāo. A situaçāo do Brasil, no entanto, mostra uma situação inversa, com uma tendência ascendente de $6,9 \%$ ao ano na detecção de casos (Organização Pan-americana da Saúde, 1988).

Atualmente, de todas as Américas, o Brasil detém $85 \%$ dos pacientes de hanseníase, apresentando em 1994 a maior taxa de detecção historicamente observada, 
com 442.481 doentes em registro ativo, sem contar que há uma estimativa conservadora para a doença em torno de 600.000 indivíduos. O Brasil apresenta, portanto, uma alta endemicidade da doença, possuindo um coeficiente de prevalência de 2,0 a 4,9 por mil habitantes, o que o coloca em quarto lugar no mundo em número de casos, suplantado apenas pela Índia, Birmânia e Nigéria.

$O$ aumento da deteç̧ão de formas paucibacilares verificado recentemente no Brasil, significa que pessoas com menos susceptibilidade e maior resistência estão se infectando. Isso quer dizer que para essas pessoas estarem se infectando é necessário que haja um aumento da força de transmissão, causada principalmente por uma exposição mais intensa e prolongada com a micobactéria. Trata-se de um dos poucos países em que se verifica crescimento desta doença e em que a velocidade deste aumento é a maior do mundo.

Das cinco macrorregióes do Brasil, quatro são de alta prevalência: Norte $(4,54 / 1.000)$; Centro-Oeste $(3,41 / 1.000)$; Sudeste $(1,72 / 1.000)$ e Sul $(1,24 / 1.000)$. O Nordeste registra média prevalência $(0,86 / 1.000)$, mas, no entanto, este seu menor índice é devido não a um número menor de doentes, mas à baixa notificação. Esta região apresenta a maior taxa anual de crescimento na detecção da doença $(11 \%)$, enquanto as regiōes Sudeste e Sul apresentam média de crescimento anual em torno de $3 \%$. Esses dados corroboram os de Lombardi, ${ }^{2}$ que apontam ter a hanseníase encontrada em todo o território brasileiro uma distribuição desigual e, portanto, com áreas de baixa, média e alta endemicidade.

\section{A SITUAÇĂO DA SAÚDE E DA HANSENÍASE EM CAMPINAS}

Com uma população estimada em 912.844 pessoas habitando uma área de $781 \mathrm{Km}^{2}$ no interior do Estado de São Paulo, a $95 \mathrm{Km}$ de sua capital, Campinas apresenta uma renda per capita mais do que duas vezes superior à da média nacional e exibe um grau de crescimento e desenvolvimento significativo em relação ao País. O município apresentou, na década de 70 , uma taxa média de crescimento populacional da ordem de $5,7 \%$ ao ano. Na década de 80 , esta mesma taxa foi da ordem de $3,8 \%$ ao ano, bem superior à taxa média do estado, de $2,7 \%$. Ao mesmo tempo em que a população crescia, a taxa de natalidade decrescia na regiāo, de $26,60 \%$ em 1980 para 20,06 em 1991, um decréscimo correspondente a $24,59 \% .10$ A taxa de urbanização passou de $68,7 \%$ em 1940 para $89,3 \%$ em 1970 e $94 \%$ a partir de 1980."1

9 Lombarol, C. Hanseniase: epidemiologia e controle. São Paulo: Imprensa Oficial do Estado de São Paulo, 1990.

10) Siad. Perfil Municipal, São Paulo, 1993.

11 "Campinas - Subsídios para a discussão do Plano Diretor"/IE-UNICAmP, 1990. 
Não só o município, mas também a região administrativa de Campinas passou a atrair fluxos migratórios crescentes, e na década de 70 tornou-se o principal destino da migração estadual, com relação "migrantes/população" superando todas as demais regiōes, inclusive a da Grande São Paulo. Mesmo com um declínio acentuado na década de 80, a populaçāo aumentou de 3.196 .969 habitantes em 1980 para 4.382.452 em 1991, com um incremento populacional de $37,05 \%$.

Entre 1980 e 1991, o consumo de energia elétrica nesta região passou de $5.812 .838 \mathrm{MWh}$ para $11.001 .918 \mathrm{MWh},{ }^{12}$ um aumento de $89,26 \%$, muito superior ao índice de crescimento populacional, o que confirma um significativo crescimento das atividades econômicas durante um período que se caracterizou, no País, por depressão econômica. Desse modo, o município de Campinas que, em 1970, se apresentava como uma capital regional de médio porte, transformou-se num dos maiores aglomerados urbanos do Brasil.

A presença cada vez mais numerosa de migrantes tem promovido uma grande pressão nos serviços sociais existentes que, na maioria dos casos, não estão aptos a incorporá-los ou a se orientarem pelos problemas que os atingem. É evidente que tal situação concorre para intensificar os problemas na área social, em geral, e na da saúde, em particular. Enquanto a populaçăo favelada somava, em 1971, 3.090 indivíduos, com um índice de crescimento de $1.533,33 \%$, ela sobe para $47.380 \mathrm{em}$ 1981 e, com um índice de crescimento de $3.129 .49 \%$, alcança o número de 96.700 em 1991. ${ }^{13}$

No que se refere às condições sanitárias, a cidade possui índices de atendimento público domiciliar bastante satisfatório, tanto no que diz respeito ao abastecimento de água quanto no serviço de coleta e tratamento de esgoto. De acordo com dados da Prefeitura, $96 \%$ da população urbana é servida pela rede de água e $81 \%$ pela de esgoto no ano de 1991.

Com relação às condiçōes de saúde, a região administrativa de Campinas tem revelado um quadro ascendente. $O$ índice de mortalidade infantil, um indicador geralmente aceito como um dos mais importantes para revelar as condições de saúde de uma população, mostra que entre 1980 e 1991 houve uma queda de 41,14 por mil habitantes para $23,24 .{ }^{14}$ Tal diminuição resulta da queda relativa nos índices da mortalidade advinda de fatores exógenos, tais como as condições de vida, o meio ambiente, o saneamento básico e a assistência médico-preventiva.

Com uma população de 912.844 habitantes e um total de 1.076 pacientes de hanseníase em registro ativo, Campinas tem uma prevalência de 1,17 casos por mil habitantes (o sexo masculino sobrepuja levemente o feminino), o que é considerado alto pela Organização Mundial da Saúde.

12 Seade. Perfil Municipal, São Paulo, 1993.

13 "Campinas - Subsídios para a discussāo do Plano Direlor"/IE-Unicamp, 1990.

14 Siade. Perfil Municipal, São Paulo, 1993. 
Campinas possui 40 unidades básicas de saúde, das quais 5 estão estruturadas para o atendimento da hanseníase. Dentre estas, o Centro de Saúde I (atual Policlínica) atende $93,6 \%$ dos pacientes doentes. Como mostra a Tabela I, a forma Virchoviana, ou seja, a mais contagiante, constitui a maioria dos casos. Este dado revela também que o diagnóstico realizado é na maioria das vezes tardio, ou seja, já no estágio mais avançado da doença.

Quanto ao controle dos comunicantes, um fator essencial para impedir a progressão da transmissão da hanseníase, os dados obtidos na Policlínica I de Campinas revelam uma situação precária, comı apenas $23,8 \%$ do total avaliados e sob controle. A vacinação $B C G$-ID (intradérmico) aos comunicantes exerce alguma proteção contra o aparecimento das formas multibacilares da hanseníase, mas o controle precário dos comunicantes não permite que esta forma preventiva seja adotada de forma extensiva. Deste modo, a endemia não vem sendo controlada, confirmando a análise realizada por Gonçalves ${ }^{15}$ que, considerando o País como um todo, conclui que apenas $1 \mathrm{em} 3$ comunicantes encontra-se sob vigilância epidemiológica.

TABELA I

DISTRIBUIÇĀO DOS CASOS DE HANSENÍASE SECUNDO A FORMA CLÍNICA - CAMPINAS - JANEIRO/1990

\begin{tabular}{lrr}
\hline FORMAS CLINICAS & \multicolumn{2}{c}{ CASOS REGISTRADOS } \\
\hline VIRCHOVIANA & 685 & $\%$ \\
DIMORFA & 51 & 63,7 \\
INDETERMINADA & 1781 & 4,7 \\
TUBERCULOIDE & 162 & 6,5 \\
\hline TOTAL & 1.076 & 15,1 \\
\hline
\end{tabular}

Fonte: Centro de Vigilância Epidemiológica, Secretaria de Saúde do Estado de Sảo Paulo.

15 Gonçatvfs, A. G. fpidemiologia e controle da hanseniase no Brasil, 1989. (Mimeo.). 


\section{4}

\section{OS MEIOS DE CONTROLE DA HANSENÍASE EM CAMPINAS}

\section{A IMPLEMENTAÇÃO DO SUS}

Antes de focalizar os meios de controle da hanseníase em Campinas é necessário ampliar um pouco a visão do problema, de tal modo que o sistema público de saúde se torne visível e, em seu interior, a questão da hanseníase possa adquirir uma proporçāo mais exata.

O processo de intervenção estatal na área da saúde no Brasil ocorreu em três períodos, caracterizando padrões distintos: o dos governos populistas, o dos governos burocrático-autoritários e o que corresponde à transição democrática. Os governos populistas imprimiram um padrão de política social caracterizada por um corporativismo fragmentado que dividia a população trabalhadora em várias categorias com privilégios diferenciais. O período autoritário-militar distinguiu-se por uma grande centralização política, financeira e operacional de todo o sistema de saúde, através de repasse de verbas do setor público ao privado. Esta ampliação do poder de intervenção estatal permitiu um enorme crescimento do setor privado, provedor direto ou indireto de equipamentos e de serviços médicos, propiciando a mercantilização e o empresariamento da medicina numa escala nunca antes atingida. Este crescimento do setor saúde engendrado por este sistema foi, no entanto, descontrolado, desconsiderando os problemas coletivos e gerando grande desperdício de recursos.

O período de redemocratização do País, que começou a ocorrer no final dos anos 70, caracterizou-se na área da saúde por várias tentativas de reforma no siste$\mathrm{ma}$, tendo em vista o propósito de estabelecer uma melhor racionalidade e oferecer melhores condiçōes de saúde à população. Nos anos 80 , com o agravamento da crise econômico-financeira, tanto o planejamento como a gestão do sistema de saúde então vigentes tornaram-se impraticáveis.

Após tentativas de implementação de vários projetos que propunham a implantação de serviços básicos de saúde como porta de entrada para um sistema mais 
abrangente e racional houve, a partir de 1983, os primeiros convênios das Ações Integradas de Saúde (AIS), que envolveram o Ministério da Saúde, o Ministério da Previdência e Assistência Social e as Secretarias Estaduais e Municipais de Saúde.

Nesse esquema, o município passou a representar uma instância integradora de todo o sistema de saúde, contribuindo decisivamente para as funções de organização, gestão, execução e fiscalização das ações e serviços disponíveis à comunidade. Pretendia-se, assim, promover uma maior racionalidade operativa - integrando num único sistema as diversas instâncias, públicas e privadas, que ofertavam serviços de saúde - e, ao mesmo tempo, permitir a cada indivíduo o direito ao acesso a todos os níveis de assistência. O controle dos serviços pela população, através da sua participação nas instâncias colegiadas de decisāo, foi o mecanismo previsto para promover não só uma melhor eficácia e eficiência daqueles, como também para direcionar a medicina para os verdadeiros problemas da comunidade.

Em março de 1986, o Ministério da Saúde promoveu a VIII Conferência Nacional de Saúde, na qual teve lugar uma ampla discussão sobre os principais problemas de gerenciamento, controle e administração de saúde da população brasileira, envolvendo amplos setores organizados da sociedade. As diretrizes emanadas desta Conferência serviram como referência e base para o decreto presidencial que criou o Sistema Unificado e Descentralizado de Saúde (SUDS), em junho de 1987.

O SUDS promoveu um efetivo processo de transferência de recursos materiais, humanos e financeiros para os estados e, através destes, para os municípios, intensificando a política iniciada com as Ações Integradas de Saúde (AIS), em vigor desde 1983. Com a transmissão de um considerável grau de responsabilidade para o poder local, pretendeu-se promover um controle do sistema pela população. Além disso, o processo de descentralização tornou possível uma melhor adequação do sistema a cada uma das muitas realidades regionais de um país de dimensóes continentais como o Brasil.

Esse processo culmina com a promulgação da nova Constituição brasileira em 1988, em que fica explicitada a obrigação do município - através da cooperação técnica e financeira da União e do estado - em providenciar serviços de atendimento à saúde de toda a população por intermédio de um Sistema Único de Saúde que passou a ser denominado SUS, cujos objetivos expressos sāo: a universalizaçāo da assistência; a organizaçăo dos serviços sob a forma de redes regionalizadas e hierarquizadas; a descentralização dos serviços; um novo relacionamento entre o setor público e o setor privado; e a participação comunitária.

O eixo do sistema de saúde passou a ser o de uma rede básica pública de serviços de saúde que atua fora da lógica de mercado, articulando as demandas por serviços médicos com o conjunto de ações de maior complexidade, de retaguarda. Nesse sistema, é admissível uma composição com o setor privado, o qual não se cogita erradicar. Pretendeu-se, com isso, dar um sentido orgânico e hierarquizado a um conjunto de unidades de saúde que antes eram totalmente divorciadas entre si; 
pretendeu-se também eliminar a tradicional dicotomia entre medicina preventiva e medicina curativa, uma vez que o significado de saúde deveria passar a ser muito mais centrado nos problemas vividos pela comunidade.

Neste sistema, uma equipe de saúde que inclui médicos, psicólogos, assistentes sociais e enfermeiras, entres outros profissionais, deveria formar o cerne de cada Posto de Saúde que, por sua vez, receberia equipamentos diagnósticos e clínicos suficientes para dar conta da grande maioria dos casos de doenças apresentados pela população. Com isso, o hospital teria uma função de mera retaguarda, para onde seriam referidos pacientes a partir dos Postos de Saúde.

A municipalização dos serviços de saúde, uma realidade na maioria dos municípios dos estados mais desenvolvidos do País, em sua implementação prática, no entanto, apresenta muitos problemas e está longe de corresponder aos seus objetivos iniciais. Entre os vários problemas encontrados destacam-se a forma inadequada de financiamento do sistema através de convênio e repasse financeiro da esfera federal para o município; ${ }^{1}$ a falta de cultura de gerenciamento do serviço, o que ocasiona irracionalidade organizacional e desperdício de recursos; ${ }^{2}$ a herança de uma estrutura burocrático-administrativa inadequada; ${ }^{3}$ a ausência de tradição em trabatho em equipe ${ }^{4} \mathrm{e}$ o frágil controle da comunidade sobre o serviço. ${ }^{5}$

Um aspecto também criticável na implementação do SUS refere-se ao sacrifício de uma idéia fundamental, contida no projeto original da reforma sanitária: a integração da clínica com a medicina coletiva, num modelo em que a clínica se submete a um sistema maior, que considera os problemas de saúde como apenas parcialmente médicos, ao mesmo tempo em que leva em conta os fatores sociais. ${ }^{6} \mathrm{Nes}$ se contexto, a racionalização do sistema pretendida com a descentralização e municipalização dos senviços de saúde, embora tivesse diminuído o peso do hospital, deixou praticamente intocado o paradigma positivista que percebe a doença como

1 Queiroz, M. S. \& Viana, A. L. Organizaçăo e gerenciamento dos serviços de saúde em Campinas. In: Rev. Adm. Públ., 28(4): 27-37, Rio de Janeiro, 1994.

Palm, J. S. Reiorma Sanitária e a Municipalizaçāo. In: Saúde e Sociedade, 1(2): 29-47, São Paulo, 1992.

2 Junqueira, L. A. P. \& INOjosa, R. M. Gestão dos serviços públicos de saúde. In: Rev. Adm. Públ. 26(2): 20-31, Rio de Janeiro, 1992.

3 Felicielıo, D. Modelos assistenciais e Política de Saúde no Brasil. In: Rev. Adm. Públ., 26(2): 62-78, Rio de Janeiro, 1992.

LUz, M. T. Notas sobre as Políticas de Saúde no Brasil de transição democrática. In: Saúde em Debate, 32: 27-32, junho, 1991.

4 Machado M. H. \& Carsalade, M. I. Os trabalhadores em saúde e o SUS. In: Rev. Adm. Públ., 26(2): 172-178, Rio de Janeiro, 1992.

5 Quetroz, M. S. CAstro, M. H. G. \& Vuna, A. L. A organização dos serviços de saúde: uma avaliação da experiência de Campinas. In: Cadernos de Pesquisa, n. 26, Nepp/Unicamp, pp. 1-78. Campinas, 1993.

6 MACHADO, F. A. Sugestōes para um modelo alternativo de atençāo à saúde. In: Saúde em Debate, n. 31: $31-35,1991$. 
"coisa" limitada à sua dimensão física, cujo espaço se confunde com uma determinada estrutura biológica.'

O desafio com que se depara o desenvolvimento futuro da reforma sanitária relaciona-se inevitavelmente com a reconciliação entre uma clínica que dimensione o caráter individual e subjetivo da doença e o saber contido em várias outras disciplinas tais como a epidemiologia, a sociologia, a psicologia, a antropologia e a medicina social e coletiva. Neste novo modelo, as ações de saúde, além de incorporarem a assistência médica, deveriam se organizar por um conjunto de questōes que as transcendam, envolvendo basicamente o meio ambiente e a experiência social de vida da comunidade. O problema da saúde e doença, nesse contexto, deixaria de ser percebido apenas como dimensão biológica e passaria a envolver uma concepção holística do ser humano e do meio social e cultural em que vive. Uma nova base tecnológica para a implementação desta proposta exigiria, evidentemente, uma mudança radical nos princípios dominantes da medicina e da saúde, inculcados na educação médica e consubstanciados na crise de todo o setor de saúde que, hoje, adquire dimensóes crônicas e agudas ao mesmo tempo. ${ }^{8}$

Embora mais racional na teoria, a implementação prática dessas novas idéias na área da saúde não tem sido fácil devido a vários problemas, inclusive às circunstâncias locais imprevisiveis para um plano de natureza macropolítica. Nesse contexto, tornar um sistema múltiplo em sistema único de saúde controlado e administrado pelo poder local é uma questăo que a maioria dos municípios brasileiros não se encontra equipada para resolver.

Embora a transferência de recursos financeiros para a saúde nos municípios seja cada vez maior, estes ainda estāo longe de poder controlar todo o sistema de saúde. Isso ocorre porque a maior parte destes recursos săo provenientes do Ministério da Saúde, que os repassa ao estado e este ao município, de acordo com o seu tamanho e produtividade. Além disso, há que se destacar, também, que ainda persistem vários aspectos da antiga multiplicidade administrativa como, por exemplo, o fato de haver funcionários contratados por instâncias estaduais ou federais que atuam junto com os da própria prefeitura.

Em outro estudo, tendo como referência principal o município de Campinas,? foram detectados quatro pontos de estrangulamento na implementação do SUS: a dificuldade de integração e organização dos vários órgãos que participam do sistema

7 Oliveıra, A. M. F. Os dilemas da municipalização da Saúde no contexto de uma região metropolitana: o caso de Campinas. Tese de Doutoramento. IE/Unicamp, 1995.

QueIROZ, M. S. \& VIANA, A. L. Op. cil., 1994.

Querroz, M. S. O desenvolvimento da municipalização dos serviços de saúde em Campinas. In: Rev. Adm. Públ., 28(4): 27-37, Rio de Janeiro, 1994.

8 Merhy, E. E. \& Queiroz, M. S. Saúde Pública, Rede Básica e o Sistema de Saúde Brasileiro. In: Cad. Saúde Públ., 9(2): 177-184, Rio de Janeiro, 1993.

9 Queiroz, M. S. \& VianA, A. L. Op. cit., 1994. 
municipal de saúde, a incapacidade do nível regional de gerenciar o novo modelo de saúde; a forma de pagamento por produção, o que induz a um desvio produtivista no sistema e a um afastamento das questões relativas à qualidade do serviço prestado; e, finalmente, o reducionismo do modelo assistencial ao pronto atendimento. A integração entre rede básica, hospitais privados e hospitais universitários, que, pelo peso que representam, deveria se constituir no eixo fundamental principal do sistema de saúde, tem se revelado muito difícil, principalmente pela resistência dos primeiros em se deixar gerenciar por um sistema de saúde controlado pela Prefeitura.

A ausência de um poder regulador que atue em nivel regional tem, dessa forma, contribuído para a manutenção de profundos desequilíbrios no sistema de saúde, uma vez que é difícil ou quase impossível perceber e resolver vários problemas na área da saúde, tais como o controle de certas endemias e epidemias, a partir do nivel municipal.

A prática de pagar o ato médico diretamente de Brasília mostrou-se altamente inadequada para a promoção da municipalizaçāo dos serviços de saúde, pois além de ser insuficiente para remunerar estas açōes, tirou das secretarias estaduais a possibilidade de criar planos regionais como vinha acontecendo no Estado de São Paulo com o SUDS. Nesse contexto, sem se sentir responsável pela condução do sistema de saúde, o estado tem se omitido de intervir neste âmbito, desmontando áreas tais como a vigilância epidemiológica e sanitária que, entre outras, deveriam estar sob sua responsabilidade.

O problema da insuficiência dos repasses federais para a saúde tornou impossivel a continuidade de vários programas estabelecidos pelas Secretarias de Saúde em nivel municipal e estadual. Recentemente, tirante o pagamento das internaçōes, o financiamento à saúde voltou a ser uma atribuiçáo do estado, que retomou o poder de decisão e negociaçăo com relação ao montante proveniente da esfera federal destinado aos municípios. É prematura qualquer avaliação da repercussão desta medida.

Os problemas mencionados acima servem para ilustrar o profundo sentimento de isolamento do município diante das enormes atribuiçōes e responsabilidades colocadas pela municipalização dos serviços de saúde. Se isso é verdade em Campinas, é possível imaginar o que significa para a grande maioria dos demais municípios brasileiros, que estão longe de contar com recursos comparáveis. O que se observa no processo de municipalização dos serviços de saúde em Campinas é que atingiuse um ponto em que o avanço do processo, embora necessário, tem encontrado obstáculos quase intransponiveis. Dentre estes obstáculos, o sistema de convênio que financia as ações de saúde é o principal. Há um consenso, neste sentido, de que a única possibilidade de regeneração do sistema de saúde, além de aumentar os valores dos repasses, seria a mudança no sistema de convênios, com uma ênfase maior nas ações coletivas. 
De uma certa forma, apesar das críticas que o poder local dirige ao sistema de convênio e à falta de condições para implementar programas de saúde mais abrangentes que o pronto-atendimento, a verdade é que a Prefeitura financia mais de um terço da totalidade de recursos disponíveis para a saúde e, com isso, teria um peso significativo na condução de uma política de saúde que contemplasse as ações coletivas e preventivas.

No entanto, o que se observa é que o pronto-atendimento apresenta um peso avassalador entre os serviços oferecidos pela Prefeitura. É evidente que fatores culturais e políticos favorecem esta lógica, na medida em que prover um Posto de Saúde com mais médicos dando atenção à população é uma ação mais visivel, que traz maiores dividendos aos políticos que a promovem. A folha de pagamentos da Secretaria Municipal de Saúde é eloqüente no sentido de revelar que cerca de $95 \%$ de seus recursos são gastos com médicos e dentistas, o que mostra que a experiência multiprofissional é insignificante.

Esta forma de prestação de serviço tem reduzido a Rede Básica de Serviços de Saúde a uma mera porta de entrada de um sistema unidimensionalmente concentrado na incorporação da assistência médica. Esta última, ao realizar uma verdadeira triagem dos problemas de saúde da população a partir do eixo "queixa/procedimento", domina totalmente o cenário, fomentando o risco de imprimir um aumento considerável de medicalização da sociedade. Com o domínio da medicina curativa na rede básica de serviços de saúde (que corresponde a cerca de $80 \%$ da totalidade dos serviços prestados), a saúde pública e a medicina preventiva e social continuam a desempenhar um papel secundário e submisso a uma postura que, teoricamente, não mais encontra meios de se legitimar.

Ao que tudo indica, portanto, o conjunto dos problemas apontados acima constitui um reforço considerável ao paradigma positivista dominante, o qual, ao camuflar a crise no setor saúde como mera questão administrativa/gerencial, ainda dá sinais de considerável vitalidade na manutenção de sua hegemonia. Explicar o motivo desta vitalidade é uma questão que extrapola a sua utilidade e mesmo a sua consistência epistemológica para penetrar na sua compatibilidade paradigmática com vários outros componentes de natureza política e social.

\section{A HANSENÍASE NO CONTEXTO DO SUS}

A reforma do sistema de saúde, que alguns profissionais preferem denominar de mera restruturação, promovida no Estado de São Paulo a partir da década 70, ao impor um sistema regionalizado e hierarquizado, enfraqueceu o sistema centralizado e autoritário na saúde pública e, dentro desta, o modelo hegemônico imposto pela área da dermatologia sanitária no controle da lepra. Ao final da mencionada década foi introduzido um curso intensivo de seis meses na Faculdade de Saúde Pública da USP, que visava a formar um novo tipo de sanitarista, com uma visão do sis- 
tema como totalidade e com capacidade de gerenciá-lo. Outros cursos intensivos e descentralizados foram também implementados em alguns municípios do estado e em outras localidades da Capital.

Os Postos e Centros de Saúde passaram a ser gerenciados por profissionais formados por estes cursos, situação que acabou por imprimir um novo perfil ao sanitarista. Nesse contexto, a visão geral de ambulatório, que engloba o atendimento a todas as doenças, substituiu os programas verticalizados para gestantes, crianças, imunização, tuberculose e hanseníase. A estrutura vertical iniciou, com isso, uma perda irreversivel de domínio sobre o sistema que, por sua vez, passou a ser dominado pelo pronto-atendimento, a partir da demanda espontânea. Neste novo esquema, sobreviveram apenas os programas de saúde mental e da hanseníase, que ainda continuam concentrados em alguns poucos Centros de Saúde.

O sanitarista moderno tem uma visão centrada na comunidade, e não no hospital; e no conjunto das doenças, e não especificamente numa única doença. Trata-se de uma perspectiva que pretende resolver a maioria dos problemas de saúde no ambulatório e, para isso, é necessário equipá-lo com um certo nivel de apareIhos diagnósticos. A idéia de que o Centro de Saúde serve para tratar problemas simples passa a ser, sob esta ótica, um mito muito distante da realidade, porque a demanda contempla tanto casos simples como complexos e o médico, por sua vez, deve estar preparado para lidar com todos eles.

A questão é, pois, formar um sistema baseado num centro de saúde de alta resolutividade, que consiga dar conta da maioria dos problemas de saúde da população. Para isso, é necessário que o Centro de Saúde disponha de uma equipe multidisciplinar, além de um certo nivel de equipamento tecnológico. Com isso, esperase que pouca gente seja encaminhada a outros ambulatórios de referência e muito menos ainda ao hospital, que só seria utilizado em casos extremamente graves.

Segundo esta lógica, a Universidade terá que se adaptar a esta realidade, saindo do hospital e aprendendo na rede de serviços. Só aí seria possivel entrar em contato com uma diversidade muito maior de casos patológicos que não requerem a tecnologia disponivel num hospital. O hospital é considerado indispensável, mas apenas como uma retaguarda mais complexa do sistema. Neste sentido, o Centro de Saúde não é visto como uma solução de baixa qualidade para os desprovidos, mas o eixo de um sistema que pode resolver a maior parte dos problemas de saúde de toda a população.

As atividades de controle e tratamento da hanseníase fugiram a este esquema, concentrando suas atividades em poucos Centros de Saúde especializados. Embora a maioria dos técnicos do setor saúde considerem que a tendência natural será descentralizar o diagnóstico e o tratamento da hanseníase, considera-se que a inexperiência, o despreparo, o preconceito e a resistência dos profissionais da saúde desempenham um papel relevante na manutenção do velho esquema. 
Na formação da rede básica de senviços de saúde de Campinas foram contemplados, principalmente, os meios diagnósticos que, de um modo geral, são satisfatórios. Quanto às equipes multidisciplinares, embora sejam consideradas da maior importância, não houve um avanço significativo. O Centro de Saúde no qual concentramos a nossa investigação, a Policlínica I, dispõe de equipe de enfermagem, dentistas, ginecologistas, clínico, pediatra e trabalhadores de apoio. Em matéria de equipamento, conta com eletrocardiograma, Raios $X$, equipamento básico de ginecologia e outros aparehos considerados satisfatórios em seu conjunto pelos profissionais da saúde que lá operam. Há, por outro lado, um consenso de que o Centro carece de recursos humanos, especificamente, psicólogos, auxiliares de enfermagem e médicos.

Como referência na área de hanseníase para toda a região, a Policlínica I é uma instituiçăo que fazia parte da Rede Estadual de Postos e Centros de Saúde e que, atualmente, é administrada pela Prefeitura através do SUS. Seus funcionários, embora sujeitos ao controle da Secretaria Municipal de Saúde, ainda recebem seus proventos do estado. Como os salários provenientes do estado são muito inferiores aos recebidos por profissionais da Prefeitura, com responsabilidades equivalentes, há muita insatisfação quanto a este aspecto.

Apenas um de seus médicos é especialista em hanseníase. Os demais (dois), estão assumindo, paulatinamente, casos novos desta doença. Do total de três médicos, dois trabalham em período integral e um em período parcial. Quando a população regional do município era muito menor, a área de dermatologia sanitária especializada em hanseníase contava com uma equipe muito maior do que a de hoje em dia. Havia uma equipe de pelo menos três médicos, quatro enfermeiras, seis auxiliares e seis visitadores sanitários especialistas, que só tratavam desta doença. Esse serviço foi desmontado em 1992; os especialistas foram e ainda são estimulados a tratar não só de hanseníase, mas de outras doenças dentro da clínica geral. Neste processo, o Centro de Saúde ficou meses sem nenhum médico especialista em hanseníase, tendo o clínico geral e o pediatra sido treinados para diagnosticar e também tratar desta doença.

A situação constitui um verdadeiro paradoxo: à medida que o problema da hanseníase cresce como um caso de saúde pública, diminui a sua visibilidade como prioridade nas políticas públicas tanto em nível federal como local. Em 1988, houve uma campanha explicativa dos sintomas da hanseníase pela televisão, o que causou um aumento significativo da demanda pelos serviços públicos de saúde, particularmente no Norte e Nordeste. Esta campanha, no entanto, como muitas outras promovidas pelo setor público, foi interrompida e, mais uma vez, o problema caiu no esquecimento. Hoje em dia, a hanseníase não rende dividendos políticos nem científicos. Na VIII Conferência de Saúde, a questão nem sequer foi lembrada.

Com este panorama, é óbvio que a hanseníase encontra-se em pior situação do que se encontrava no tempo da dermatologia sanitária. Antes, além da Policlíni- 
cas I concentrar a maioria de suas atividades em função desta doença, os hospitais especializados, como o de Bauru, operavam com a mesma produtividade para uma demanda muito menor, em função da menor população e de casos da doença. A mudança, embora para pior, é considerada inevitável na política do SUS. A solução para a hanseníase já não é mais percebida em sua especificidade, mas no bojo de um enfoque que, além de incluir todas as demais doenças, conta com a melhora das condiçōes de vida para toda a população.

$\mathrm{Na}$ época do domínio da dermatologia sanitária não faltavam medicamentos, médicos, enfermeira e infra-estrutura hospitalar. No entanto, o foco dirigido a uma única doença reforçava o estigma existente em relação a ela. Quem entrava no Centro de Saúde especializado em lepra era leproso e, evidentemente, muitos resistiam a se submeter ao tratamento para fugir do estigma. Em função disso, houve uma compreensão de que a doença seria melhor combatida a partir do momento em que a população começasse a procurar os serviços de saúde e a se tratar, o que iria acontecer naturalmente após a sua desestigmatização. Desfocalizar a hanseníase e percebê-la como uma doença como outra qualquer foi o primeiro passo para se implementar esta estratégia. Daí a mudança de nome para hanseníase, uma vez que o termo lepra é pejorativo e derrogatório.

Apesar do aspecto positivo mencionado acima, ao perder seus privilégios $\mathbf{e}$ prerrogativas, a hanseníase foi nivelada por baixo junto às demais morbidades. Mesmo no contexto das doenças endêmicas, a hanseníase tem se situado em segundo plano, principalmente a partir da constatação de que ela não leva à morte, como pode levar a esquistossomose ou a malária. Além disso, o tratamento destas últimas é mais gratificante para a equipe de saúde porque o paciente responde mais prontamente e a cura ocorre mais rapidamente.

Várias evidências indicam, no entanto, que a hanseníase não é uma doença igual às outras, como quer a política do SUS. Mesmo admitindo que não se justifica a manutenção de especialistas exclusivos, não há condiçōes de descentralizar totalmente o seu atendimento devido, principalmente, ao despreparo dos médicos. Para capacitá-los, haveria que se promover uma mudança radical, desde a estrutura do ensino médico, cuja percepção dominante da doença é hospitalocêntrica, até uma melhora considerável no pagamento dos médicos do setor público. É preciso lembrar, neste particular, que a maioria desses são recém-formados e que percebem o seu emprego como um estágio a ser superado em seu desenvolvimento profissional. Muitos deles, sabendo que irão mudar de emprego num futuro não muito longínquo, não se interessam em capacitarem-se para lidar com a hanseníase, doença que, provavelmente, nunca irão se defrontar em outros contextos. Mesmo os que concordam com esta capacitação, acabam saindo do setor público quando encontram meIhor emprego e, assim, o investimento em seu treinamento é perdido.

Os médicos normalmente não têm condições de fazer o diagnóstico da hanseníase porque năo receberam e nem deverão receber treinamento adequado. En- 
tre as doenças endêmicas e infecciosas, a hanseníase, com o menor índice de exploração nas Faculdades de Medicina, é a que menos parece interessar. Considerada uma doença de segundo plano, própria da pobreza, ela não estimula nem o estudo nem o tratamento.

A não ser em casos extremos, a hanseníase é uma doença que não requer recursos hospitalares e, por isso, encontra-se fora do paradigma hospitalocêntrico dominante da medicina e do ensino médico. $O$ seu tratamento sempre esteve nas mãos do serviço público, também considerado marginal e pouco estimulante para os centros de formação médica. Uma vez que as escolas de medicina não formam profissionais para atuar na rede pública, o conhecimento sobre a doença é adquirido principalmente na prática, com o auxílio de uns poucos cursos de capacitação profissional.

Neste quadro, o conflito entre a política prevalente no SंUS e uns poucos médicos que insistem em defender uma política centralizada em relação à esta doença chega a ser intenso em alguns momentos. O SUS considera os médicos interessados nesta perspectiva como antiquados e retrógrados, propensos a promover uma volta da política vertical e centralizada do antigo Departamento de Profilaxia da Lepra (DPL).

Campinas experimentou uma valorização dos profissionais da saúde em 1989 e 1990, quando, então, os bons salários foram acompanhados de boas condiçōes de atendimento clínico. Neste período, as consultas duravam mais tempo e as histórias de vida eram estimuladas como um meio adequado para assessorar o diagnóstico e o tratamento. Após 1991, o salário teve uma queda violenta, o número de médicos diminuiu, assim como a produtividade e a dedicação ao serviço, prejudicando o padrăo iniciado anteriormente e contribuindo muito para a frustração da equipe de saúde.

Há um consenso generalizado entre os profissionais envolvidos de que o sistema de saúde como um todo encontra-se em crise. Na área da hanseníase, esta situação é considerada ainda mais grave. Para os cerca de 1.100 doentes cadastrados, há apenas 1 médico especialista, quando o ideal seria um médico para cada 300 doentes. Isso, para não falar da equipe multidisciplinar de saúde, encarregada de dar suporte social e psicológico ao paciente, e que praticamente inexiste na presente conjuntura.

Uma categoria profissional de nível médio considerada extremamente importante na concepção do SUS é o auxiliar de enfermagem, que assume responsabilidades importantes no dia-a-dia do Centro de Saúde. Trata-se, no entanto, de um profissional que praticamente năo se encontra disponível no mercado, tendo em vista que a política de remuneração não motiva os de bom nível intelectual a prestarem concurso. Há, além disso, poucos cursos técnicos que formam esta profissão.

A Policlínica I possui seis visitadores sanitários que realizam um serviço com a família do doente de hanseníase. Trata-se de uma categoria de nível médio, funcio- 
nal ao modelo de atenção dominado pela dermatologia sanitária e que se encontra atualmente em extinção, com um pessoal desmotivado e já próximo de obter aposentadoria. Este pessoal recebeu treinamento em medicina preventiva, em vacinação e em elementos de epidemiologia com atenção voltada para algumas epideminas, entre elas a tuberculose e a hanseníase.

O visitador sanitário foi formado por uma perspectiva paradigmática na qual ocorre uma divisão rígida entre o que é preventivo e o que é curativo, entre o que é coletivo e o que é individual na área da saúde. Como a direção do Centro de Saúde enfatiza a necessidade de encarar o problema da saúde sob uma perspectiva integral, esta funçăo especializada deixa de ter sentido.

A direção do Centro de Saúde considera que o saber adquirido pelos visitadores, relativo ao contexto social e emocional da produção e manutenção da doença, que era específico da hanseníase, deve ser repassado para todas as outras doenças. $O$ auxiliar de enfermagem deverá substituir o visitador neste ponto. Espera-se, por exemplo, que este profissional, ao executar um curativo em alguém que se machucou por causa de um acidente de trabalho, procure saber as condiçōes em que esse fato ocorreu e encaminhe o problema para um tipo de solução que inclua as condições de trabalho vividas pelo paciente. Na prática, porém, devido à carência de recursos, o que ocorre é que o auxiliar de enfermagem concentra mais de $90 \%$ das suas ações na área curativa.

No Brasil, os serviços relativos à medicina coletiva (controle de vetores, instituições de pesquisa, produção de imunobiológicos, de medicamentos e hospitais como o Emílio Ribas) foram sucateados e nada indica que esta situação possa ser revertida após a municipalização dos serviços de saúde e o SUS. As condições que dăo suporte aos serviços de saúde são consideradas insuficientes. O principal problema reconhecido é a falta de médicos, que resulta numa demanda reprimida considerável de serviços de saúde e numa grande demora no atendimento.

Já a medicação específica para a hanseníase não tem faltado, mas faltam produtos tais como copinho descartável para dar a medicação, além de material para curativo. No caso de uma neurite (inflamação dos nervos periféricos muito comum na hanseníase), falta gesso para fazer a imobilização. O Centro de Saúde carece de um sapateiro ortopédico para lesōes e deformações nos pés. Alguns exames como o de eletromiografia (necessário para avaliação do comprometimento muscular do paciente em decorrência da doença) só é possível ser realizado no hospital das clínicas da UNICAMP, após muito tempo de espera.

É também difícil a obtenção de meios para deslocar os pacientes para o Centro de Saúde. Muitas vezes estes deixam de recorrer ao serviço em função de falta de recursos para se locomover de ônibus. Cirurgias para a correção de deformaçōes nervosas, como a mão em garra, são atualmente quase impossiveis de se conseguir, da mesma forma que o são as retaguardas terapêuticas, tais como a reabilitação de estruturas de nervos e de músculos ou ainda a obtenção de uma prótese. 
Em 1990, a Prefeitura implementou um sistema de treinamento de médicos da rede pública para que pensassem na hanseníase como uma hipótese diagnóstica. O passo seguinte seria treiná-los para executar o tratamento numa forma totalmente descentralizada. Contudo, os esforços realizados até agora são insuficientes. Os grandes problemas continuam sendo a grande rotatividade da mão-de-obra na rede e a descontinuidade das políticas públicas, com a mudança de secretários e de prefeitos.

No caso de haver um doente que recusa a se tratar e pode estar contaminando os seus familiares, o Centro de Saúde não tem qualquer meio de induzi-lo ao tratamento. O máximo a que se chega é requisitar por escrito para que retorne ao Centro de Saúde. Trata-se de uma postura positiva quando se tem como parâmetro a tradição autoritária do sistema de saúde inaugurada com Oswaldo Cruz. No entanto, configura-se uma postura de omissão irresponsável quando se sabe que existem meios não autoritários de persuasão através de visitas de sanitaristas e psicólogos, mas que não são utilizados por falta de verba. Sugerir que o sistema de saúde saia em busca de patologias seria pedir um esforço absolutamente além de seus meios, considerando que o próprio sistema sequer consegue dar conta dos que procuram por ele.

Na ocasião desta pesquisa, em 1993, o serviço estava à beira do caos devido, principalmente, à recessão e, conseqüentemente, à falta de recursos, à insuficiência de médicos, aos baixos salários e à piora da qualidade de vida da população. Houve um aumento considerável da procura e dependência do serviço público em função do desemprego e empobrecimento da população. O enorme arrocho salarial promovido pelo estado e também pela prefeitura nos anos anteriores estimulava a demissão, particularmente, de médicos. Considera-se, no entanto, que a Policlínica I, apesar de todos os obstáculos, encontrava-se numa posição privilegiada, em virtude da sua boa localização e do bom ambiente de trabalho.

Embora partilhem do ideal de que a saúde e a doença devam ser percebidos num contexto que inclua dimensōes mais amplas do que o mero aspecto biológico, os médicos são unânimes em afirmar que não se pode começar um sistema de saúde sem o aspecto biológico. As dimensōes sociais e psicológicas da doença deverão ser acrescentadas paulatinamente, na medida em que o serviço receba mais recursos. Enquanto isso năo for possível, o médico improvisa com os poucos recursos de que dispöe.

\section{O TRATAMENTO E OS PACIENTES DE HANSENÍASE}

A hanseníase é uma doença sistèmica, que ataca não só a pele e os nervos periféricos, as duas áreas mais comuns de comprometimento, mas também os olhos e muitas outras estruturas. Trata-se de uma doença que envolve várias áreas médicas 
tais como a clínica geral, a imunologia, a neurologia, a ortopedia, a oftalmologia, além da dermatologia. Daí a sua dificuldade de diagnóstico e tratamento.

O tratamento pode ser complicado em função dos muitos anos de terapia e do acometimento sistêmico próprios da doença, além dos efeitos colaterais que os medicamentos produzem. A poliquimioterapia (PQT), quando surgiu, foi vista como um avanço que iria revolucionar a área da hanseníase. Hoje, já não se tem tanta certeza, embora haja um consenso de que ela é mais eficaz para a maioria dos doentes. De um modo geral, a grande vantagem da PQT repousa na diminuiçăo considerável no tempo de tratamento.

A PQT foi introduzida no Estado de São Paulo em 1988, tardiamente em relação a outros estados brasileiros. Ela começou a ser utilizada em projetos de lugares como a Faculdade de Saúde Pública e o Instituto de Saúde da USP, unidades diferenciadas, com maiores recursos do que a rede pública de serviços de saúde. $\mathrm{Em}$ Campinas, ela só chegou em 1989 em situação de experiência. Hoje, esta forma de tratamento é preconizada para ser padrão. A monoterapia tenderá a ser destinada apenas às exceções.

Apesar das suas vantagens, a PQT mexe com o sistema imunológico dos pacientes e pode causar vários problemas colaterais, entre os quais o escurecimento da pele, um efeito que concorre para aumentar a depressão e reduzir a auto-estima num número significativo de pacientes.

Atualmente, entre os 758 pacientes em tratamento na Policlínicas I, 316 se submetem à PQT. A tendência é aumentar este número até aproximadamente $80 \%$ dos pacientes. Esta forma de tratamento não se estende a um número maior de pacientes por várias razóes: alguns estão indo bem com a forma antiga; outros encontram-se em fim de tratamento e, outros ainda, por terem em seu quadro clínico incompatibilidades com a PQT, como problemas hepáticos e renais.

Normalmente, o tratamento da hanseníase pode levar oito anos ou mais, até que a baciloscopia se torne negativa. Mais cinco anos de controle são ainda necessários. É difícil convencer o paciente de que precisa continuar se submetendo ao período de controle, uma vez que não apresenta sinais e nem mal-estar relacionados com a doença. Com a PQT, o tratamento médio estimado é de 2 anos, mas nas formas paucibacilares o tempo pode ser reduzido a 6 meses. $O$ ano de 1992 registra 161 casos de cura de pacientes de hanseníase em Campinas, a maioria deles provenientes da PQT.

Verifica-se, deste modo, que sendo a cura mais rápida e o controle médico maior na PQT, o abandono do tratamento ( $0,25 \%$ dos casos) é muito menor do que o encontrado na monoterapia (cerca de $6 \%$ dos casos). ${ }^{10} \mathrm{~A}$ diminuição do abandono do tratamento entre os pacientes que se submetem à PQT mostra que a principal ra-

10 Estes números não consideram as interrupçōes momentâneas do tratamento, que ocorrem freqüentemente em funçäo da dificuldade de seguir a sua disciplina. 
zão deste fato repousa no tempo exigido pelo tratamento. No capítulo 8 , a questão do abandono de tratamento é abordada e os seguintes pontos foram considerados como fatores que concorrem para este fenômeno: a dificuldade de comunicação com o serviço de saúde; o mal-estar causado pelo tratamento; a falta de confiança no diagnóstico do Centro de Saúde, principalmente diante do fato de que outros médicos realizaram outros diagnósticos anteriormente; e, finalmente, a ignorância a respeito das conseqüências de deixar a doença sem tratamento.

Após tanto tempo de tratamento, alguns pacientes, particularmente os mais idosos, não conseguem aceitar o fato de que obtiveram alta e que estão curados. Eles se acostumaram de tal forma com a rotina do tratamento que é difícil convencê-los de que ela não é mais necessária. O hábito torna-se, às vezes, tão arraigado no íntimo do indivíduo, que mesmo a ausência de sinais da doença não o convence de que está curado. Há relatos de alguns pacientes que, ao saberem que tiveram alta, tentaram manter um compromisso com os médicos, propondo-se a tomar os medicamentos dia sim, dia não ou, então, uma vez por semana, ao invés de tomálos todos os dias.

Com já foi obsenado anteriormente, a maioria dos doentes de hanseníase são de pessoas pobres, provenientes do mundo rural, sendo poucos os de classe média ou rica. O pessoal mais idoso apresenta-se, em geral, como os casos mais graves, com várias outras seqüelas. A política de confinamento atingiu alguns desses pacientes, neles deixando, muitas vezes, marcas profundas. Casos de pessoas arrancadas de suas famílias, de seus filhos, que tiveram que abandonar o emprego, chegam a impressionar os médicos que os tratam atualmente. É importante lembrar que essa condiçăo prevaleceu até o início da década de 60, mais de dez anos após a introduçăo da sulfona, um medicamento que impossibilitava qualquer risco de contágio. Como era freqüente o doente esconder a sua condição até o ponto de não ser mais possivel, esses pacientes apresentam os casos mais graves da doença. Alguns deles encontram-se em tratamento há mais de 30 anos.

A hanseníase, por suas próprias características, resiste à modernização da prática médica. Uma vez que a vida do paciente e de sua família devem ser acompanhadas num sentido muito amplo, exigem um contato prolongado, envolvendo um vínculo do tipo "médico de família". A situação do paciente inclui dramas de vários tipos, relacionados com a situação de pobreza: a carência cultural, a desagregação familiar, o subemprego e os problemas psicológicos específicos à doença, relativos à rejeiçăo e à baixa auto-estima. Os médicos do Centro de Saúde reconhecem que é muito difícil construir com esses pacientes uma auto-imagem positiva. Mesmo entre os mais jovens, a sua auto-imagem é, via de regra, bastante negativa, uma condição que os profissionais da saúde concordam que prejudica significativamente o tratamento. Como vimos, o serviço, infelizmente, não conta com profissionais que poderiam trabalhar o lado emocional do paciente. 
Os profissionais do Centro de Saúde são unânimes em reconhecer que o problema de depressăo causada pelas condiçōes de vida afeta negativamente o tratamento. Ainda assim, estes profissionais sabem que é inevitável que a escassez de recursos do setor público afete principalmente esta área, que envolveria um trabalho mais intensivo de psicólogos, assistentes sociais e outros profissionais preocupados em perceber o processo saúde e doença no interior de uma perspectiva integral de vida.

De um modo geral, muitos doentes de hanseníase convivem com uma lesão ou dormência anos a fio, sem se preocupar. Só quando o quadro se agrava, quando aparecem outras lesões ou uma dor aguda, é que o doente vai pensar em procurar um médico. A procura espontânea por causa de uma lesão em fase inicial é a exceção e não a regra. Se o serviço estivesse equipado de uma forma mais adequada, se o tempo de consulta pudesse ser maior, o diagnóstico certamente seria muito mais freqüente.

Na maioria das vezes, o paciente de hanseníase é um migrante pobre com pouca inserção social e com baixo nivel educacional. $O$ tratamento da doença exige uma disciplina que ele não está preparado para suportar, principalmente levando-se em conta que a doença năo produz grandes problemas físicos no início de sua manifestação, enquanto a medicação geralmente produz mal-estar. Acostumado a identificar o mal-estar com doença, é comum o doente avaliar que antes do início do tratamento a sua condição era muito melhor. A falta de confiança no tratamento, a ansiedade produzida pelos exercícios físicos necessários durante o tratamento, a ausência de melhora visivel por um longo tempo, tudo isso vai ao encontro de uma situação não propícia à cura.

A grande rotatividade de mão-de-obra, existente em função dos baixos salários, causa um grande prejuízo para todas as doenças mas, principalmente, para a hanseníase, que exige um treinamento específico e contempla um tratamento de longa duração. Os pacientes sempre ficam desapontados quando constatam que qualquer membro da equipe de saúde, especialmente o médico, mudou. A confiança no profissional e o vínculo afetivo, aspectos importantes da clínica, não podem ser oferecidos pelo serviço. 


\section{CARACTERIZAÇÃO SOCIOLÓGICA E REPRESENTAÇÕES SOBRE O MODO DE VIDA}

A partir da metodologia descrita no primeiro capítulo deste livro, a pesquisa encontrou 45 doentes ( 30 homens e 15 mulheres) e 164 comunicantes ( 74 homens e 90 mulheres) em 34 famílias. Foram realizadas entrevistas envolvendo 102 indivíduos, entre doentes e comunicantes. Os próximos capítulos referem-se às entrevistas realizadas com os indivíduos destes grupos amostrais. Este capítulo inicia-se com uma caracterização sociológica e prossegue com uma análise das representaçōes sociais destes indivíduos sobre as suas condiçōes gerais de vida.

A maioria (35) dos indivíduos do grupo amostral de doentes é de classe social baixa, que podem ser divididos entre 22 pobres e 13 miseráveis que residem em barracos de favelas. Apenas dois, levando-se em consideração fatores tais como renda, nivel de educaçăo e habitação, podem ser consideradas como de classe média e oito de classe média-baixa. Este quadro é consistente com a representação corrente que se tem da hanseníase, ou seja, a de uma doença típica da pobreza.

Quanto ao grupo amostral de comunicantes, de um modo geral, não há discrepâncias significativas em comparação com a amostra de doentes, a não ser no tocante ao gênero e à composição etária. Entre os comunicantes, ao contrário do que ocorreu com os doentes, há uma predominância significativa de mulheres. Dos 164 indivíduos pesquisados, 74 são do sexo masculino e 90 do sexo feminino.

A idéia de família que norteia a pesquisa baseia-se na unidade domiciliar, ou seja, os parentes que habitam uma mesma residência. Não foi encontrada uma única situação em que um residente domiciliar não pertencia à família através de laços consangüíneos. A maioria dos casos (24) consiste de unidades familiares compostas de agregados (além do núcleo pai-mãe-filhos, freqüentemente, noras, genros, netos ou sobrinhos). Das demais famílias, sete são tipicamente nucleares, ou seja, consistem de pai, mãe e filhos, duas consistem apenas do casal e uma vive só. Na maior parte dos casos, as famílias são numerosas: quinze delas apresentam sete ou mais membros habitando a mesma residência. 
A maioria das famílias dos doentes (21) é de migrantes provenientes do meio rural, dos quais 11 são procedentes do Estado de São Paulo, inclusive da regiáo de Campinas, e 10 de outros estados.

Focalizando a atenção neste universo sob um ponto de vista individual, dos 45 doentes encontrados, 14 são solteiros, 21 casados, 6 viúvos e 4 separados. Estes números expressam uma percentagem mais alta do que a normal em indivíduos que se encontram sós na condição de solteiro, separado ou viúvo, visto ser considerável o número de indivíduos em idade de acasalamento. É certo que a hanseníase concorre para explicar esta condição, tendendo a levar o indivíduo ao isolamento.

Por grupo de idade, predomina, entre os doentes, indivíduos com idade superior a 30 anos, principalmente do grupo etário que vai dos 30 aos 40 anos. Entre os comunicantes, predomina uma população jovem com menos de 30 anos, como mostra a tabela abaixo:

TABELA I

DISTRIBUIÇÄO DE PACIENTES (H) E DE COMUNICANTES (C) DE ACORDO COM A FAIXA ETÁRIA

\begin{tabular}{llr}
\hline & C & $H$ \\
\hline ATÉ 10 ANOS & 43 & 0 \\
DE 10,1 A 20 ANOS & 29 & 02 \\
DE 20,1 A 30 ANOS & 27 & 07 \\
DE 30,1 A 40 ANOS & 29 & 13 \\
DE 40,1 A 50 ANOS & 11 & 05 \\
DE 50,1 A 60 ANOS & 13 & 08 \\
+ DE 60 ANOS & 12 & 10 \\
\hline TOTAL & 164 & 45 \\
\hline
\end{tabular}

Com relação à composição ocupacional entre doentes e comunicantes maiores de 16 anos, os números revelam uma alta incidência de trabalhadores braçais $\mathrm{e}$ de aposentados e pensionistas, como demonstra esta outra tabela: 


\section{TABELA II}

DISTRIBUIÇÃO DE PACIENTES (H) E COMUNICANTES (C) MAIORES DE 16 ANOS DE ACORDO COM A OCUPAÇÃO

\begin{tabular}{lll}
\hline & $\mathrm{C}$ & $\mathrm{H}$ \\
\hline DESEMPREGADO & 10 & 04 \\
APOSENTADO, PENSIONISTA & 16 & 14 \\
DO LAR & 24 & 04 \\
EMPREGADA DOMÉSTICA & 09 & 03 \\
TRABALHADOR RURAL & 03 & 03 \\
OPERÁRIO INDUSTRIAL & 12 & 02 \\
EMPREGADO NO SETOR SERVIÇO & 15 & 04 \\
AUTÔNOMO & 13 & 08 \\
PEQUENO EMPRESÁRIO & 02 & 03 \\
\hline TOTAL & 104 & 45 \\
\hline
\end{tabular}

Embora estes números expressem um quadro que não é significativamente diferente da condição de emprego para a população trabalhadora em geral (taxa de desemprego: doentes $8,8 \%$; comunicantes $9,4 \%$ ), é necessário enfatizar a grande instabilidade no emprego que acompanha o trabalho dos doentes de hanseníase. Além disso, uma considerável proporção dos que se qualificam como autônomos compreende ocupações esporádicas, "bicos" e outras atividades sem forma contínua, como a de ajudante de pedreiro, pintor de parede ou outra ocupação equivalente. Entre os aposentados e pensionistas, a maior parte consiste ou de indivíduos que se aposentaram por tempo de serviço ou de esposas que enviuvaram. Em apenas dois casos foi encontrada uma situação de indivíduos em idade de trabalho que recebem pensão, ocasionada pela condição de serem doentes de hanseníase.

Quanto à renda dos grupos amostrais de doentes e comunicantes, na maioria dos casos (37 entre os doentes e 88 entre os comunicantes) os indivíduos recebem entre 1 e 5 salários mínimos, com exceção apenas de 8 doentes e 18 comunicantes, que recebem um valor superior. Embora esses números sejam compatíveis com a realidade disponível para a população trabahadora brasileira, a hanseníase acarreta perdas salariais na medida em que pode implicar dificuldades de trabalho manual e pesado, além do tempo gasto com tratamento no centro de saúde e seqüelas medicamentosas.

Com relação à renda familiar, a maioria das famílias (21) recebe entre 3,1 e 8 salários mínimos, das quais 11 recebem valor superior a este e 12 um valor inferior. Quando se pensa em renda per capita, a maioria (30) recebe um valor inferior ou igual a 3 salários mínimos e, em apenas 4 casos, encontrou-se um valor superior. 
Levando-se em consideração os doentes e comunicantes com idade superior a 16 anos, temos a predominância de um baixo nível de escolaridade, como mostra a tabela abaixo:

TABELA III

DISTRIBUIÇĀO DOS PACIENTES (H) E COMUNICANTES (C) DE ACORDO COM O NÍVEL DE ESCOLARIDADE

\begin{tabular}{lc}
\hline NIVEL DE INSTRUÇÄO & $\mathrm{C}+\mathrm{H}$ \\
\hline ANALFABETO & 19 \\
SEMI-ANALFABETO (- DE 4 ANOS DE ESCOLARIDADE) & 48 \\
ELEMENTAR (4 ANOS DE ESCOLARIDADE) & 61 \\
PRIMÁRIO COMPLETO & 14 \\
COLEGIAL COMPLETO & 06 \\
SUPERIOR & 01 \\
\hline TOTAL & 149 \\
\hline
\end{tabular}

\section{SITUAÇĀO DE VIDA E DE TRABALHO}

Como é possível apreender dos dados contidos no tópico anterior, os grupos amostrais de doentes e de comunicantes são constituídos, principalmente, de indivíduos pobres, que partilham condições de vida precárias no interior de um contexto mais amplo de instabilidade econômica, política e social, em sintonia com o destino das camadas trabalhadoras não especializadas do Brasil. Grande parte dessas famílias, com a exceção das poucas de classe média, vive em constante estado de tensão provocado por fatores como: a baixa remuneraçāo do trabalho, a instabilidade no emprego, a falta de serviços públicos de apoio social, a ameaça representada pelo crime e o estado de carência em geral, além da própria situação da doença.

Sem organização sindical ou de qualquer outra ordem, essa massa urbana tem sido definida pela literatura, principalmente a partir do conceito marxista, de exército industrial de reserva, ou seja, aquela população desorganizada que, embora permaneça às margens do sistema produtivo, influi decisivamente no processo de acumulação de capital pela sua simples situação de disponibilidade como mão-deobra de reserva, regulando, assim, a remuneração da força de trabalho e permitindo a acumulação de capital. Trata-se de uma perspectiva que complementa e enriquece os conceitos funcionalistas contidos na teoria sociológica da marginalidade.

É possivel delinear duas vertentes teóricas importantes ao focalizar o problema da pobreza urbana. Uma dessas vertentes percebe este problema mais como 
responsabilidade do sistema social dominante; já a outra o percebe mais como responsabilidade de uma subcultura. Este último ponto de vista, proveniente do trabaTho de Oscar Lewis ${ }^{1}$ e de seus seguidores, focaliza os fenômenos da pobreza sob o ponto de vista cultural, caracterizado fundamentalmente por um sistema de normas e valores que diferenciam a população pobre do resto da sociedade.

De acordo com Lewis, a subcultura da pobreza comporta os seguintes traços: forte referência ao imediato, incapacidade de adiar a gratificação para um futuro mais ou menos planejado, falta de planejamento familiar e social, iniciaçăo sexual precoce, incidência relativamente alta de abandono de mulheres e crianças, tendência à orientação feminina ou maternal, predisposição ao autoritarismo, sentimento de marginalização, débil estrutura do ego e falta de sentido histórico.

O primeiro ponto de vista, que focaliza o problema da pobreza como de responsabilidade do sistema social dominante, influenciado pela corrente marxista, critica o conceito de cultura da pobreza desenvolvida por Lewis na medida em que esta desconsidera a dimensão estrutural da sociedade mais ampla, a qual, em última instância, define e promove aquele campo cultural. O sistema de estratificação, de desigualdade e de dominação, de acordo com esta postura, não resulta da cultura da pobreza, mas, pelo contrário, a promove através da exclusão dos pobres nos campos ocupacional, educacional e político.

Alba Zaluar traduz bem, em poucas palavras, esta posição:

Duplamente excluidos por serem 'outros' e por serem 'incultos' e 'perigosos', os pobres urbanos vivem, neste olhar etnocêntrico e homogeneizador, $o$ avesso da civilização. O que os exclui nāo é o seu propalado fatalismo, desmotivação para o trabalho, apatia e resignação, nem a sua exclusão no campo educacional é consequência de uma suposta restrição no seu estoque simbólico. Sublinhar a cultura da pobreza neste caso termina por desviar a atenção das próprias relaçōes de poder e por alimentar as políticas públicas que perpetuam a desigualdade. ${ }^{2}$

Não é difícil reconhecer verdades, embora parciais, nestas duas posturas teóricas e encontrar razóes que as sustentam. Percorrer bairros de periferia urbana brasileira com um diário e um gravador, entrevistando seus moradores, com toda certeza revela a opressão tanto de aspectos culturais endógenos como de um sistema social que engendra e perpetua esta realidade. A nossa experiência demonstra ser im-

1 Lewis, O. Introducción a la vida. Ciudad de México: Ed. FCE, 1966.

LEWIS, O. The culture of Poverty. In: Moynihan, D. P. (Ed.) On understanding Poverty. New York: Basic Books, 1969.

2 Zaluar, A. A máquina e a revolta. São Paulo: Brasiliense, 1985. 
possível dissociar estes dois aspectos. ${ }^{3} \mathrm{Em}$ determinados contextos, um ou outro aparecem com maior notoriedade.

É evidente que uma abertura cultural teria o poder de trazer oportunidades que, talvez, permitissem escapar das condiçōes opressivas provenientes da estrutura social mais ampla. Não há nenhuma prova concreta que permita afirmar com segurança que a estrutura social capitalista exija necessariamente a perpetuaçăo da miséria. Embora muitos teóricos insistam em afirmar que o capitalismo é indissociável da exploração, opressão e pobreza, a história tem mostrado fortes indícios de muitas circunstâncias em que a população em geral, incluindo as camadas miseráveis, insiste em perceber o desenvolvimento do capitalismo como uma possibilidade associada mais com libertação do que com opressão.

Não há dúvida, no entanto, que no momento histórico em que ocorreu esta pesquisa os sinais de opressão eram maiores devido à situação de crise e de depressăo econômica. Neste contexto, os indivíduos manipulam a realidade tendo em vista propósitos imediatos de sobrevivência, numa situação que thes é hostil.

De qualquer modo, defendemos o ponto de vista, ancorado nas idéias de Weber, de que a realidade é sempre maior do que a teoria que a representa, num sentido simplificado e provisório. Ao invés de constituir uma dimensão ontológica, a teoria seria, nessa perspectiva, apenas um meio ou um instrumento que permite apreender da realidade alguns aspectos relevantes. Embora necessite de uma teoria, o mergulho na realidade teria o efeito de diluí-la numa experiência que a transcende.

Aproximando mais de perto o objeto de nossa investigação, no que diz respeito à situação geral de vida, trabalho e lazer, alguns pontos se destacam das entrevistas realizadas com os grupos amostrais pesquisados, cujos trechos foram selecionados abaixo: as dificuldades encontradas no convívio e sobrevivência urbanos, o isolamento sofrido pela falta de socialização e lazer, o refúgio procurado na religião pelas mulheres e na bebida pelos homens, a solidariedade encontrada nos vínculos familiares e de vizinhança, tendo a mulher um papel central.

Como está, a situaçāo é muito difícil, a gente chega em casa de saco cheio depois de tanto trabalho, abre a geladeira e está vazia. A gente trabalha, trabalha e nunca tem nada e ainda tem que ouvir a mulher reclamando da situação, esquentando ainda mais a cabeça. A vida que a gente leva é uma vidinha. Apesar de tudo, eu não gostaria de voltar para o sítio. Aqui tem mais movimento, mais gente na rua. (Comunicante, 34 anos, ajudante de pedreiro)

3 Esta inconsistência na definiçāo de um fato que comporta definiçōes antagônicas foi muito bem analisada por Lèvi-Strauss quando diz que a guerra, por exemplo, pode ser resultado tanto de uma defesa legítima da pátria como de experimentos realizados por fabricantes de canhōes. Ver Lèvi-Strauss, C. Antropologia Estrutural. Sāo Paulo: Tempo Universitário, 1970. 
Eu não me sinto bem no trabalho porque não há segurança alguma. $A$ gente não é registrado e, para não ficar sem serviço, é obrigado a pegar qualquer coisa. Fazer massa o dia inteiro é muito cansativo, mas graças a Deus eu tenho boa saúde. (Comunicante, 48 anos, ajudante de pedreiro)

Eu tenho muitas preocupações com a família, com um dos irmãos que anda em má companhia, com o outro que está desempregado, com o sobrinho que está doente, com o meu pai que foi operado e com a minha irmã que precisa fazer hemodiálise três vezes por semana. A situação ficou ainda mais difícil quando soube que estou com hanseníase. (Doente, 24 anos, contínuo)

Como quase dois terços das famílias estudadas são provenientes do mundo rural, quase sempre as suas representaçōes sobre a situação da vida que estão levando no meio urbano remetem a uma comparaçāo com a vida que levavam antes. Embora as dificuldades encontradas nesta última circunstância fossem constantes, a totalidade das entrevistas revela que a presente situação é pior do que a anterior. Os pontos levantados para sustentar esta avaliação referem-se, especificamente, à melhor qualidade e maior abundância dos alimentos, à ausência de tensão causadas pelo ambiente de criminalidade e a uma melhor situação de lazer relacionada com eventos sociais.

Eu gosto muito mais da roça do que da cidade, mas o problema é que a roça não está oferecendo mais nada para a gente. Se eu pudesse adquirir um pedaço de terra voltava correndo para lá. (Comunicante, 48 anos, ajudante de pedreiro)

Quando jovem, eu passei muita privação. Morava no sítio, levantava às quatro da manhã e trabalhava duro o dia todo. Mas hoje a situação é ainda pior aqui na cidade, com o custo de vida alto, os filhos sem emprego e os bandidos do bairro ameaçando. Tem dia que não sei o que colocar na mesa porque não tem nada para comer. Esse problema a gente não tinha quando vivia na roça. (Doente, 60 anos, pensionista)

Desde que saimos do sítio, tudo ficou muito mais difícil. Aqui, não tenho amigos. No sítio, as pessoas são mais humanas, mais simples e a gente se entendia melhor. Aqui eu me sinto como se fosse velha. Não posso ir a um cinema ou a uma festa porque não tenho nem roupa, nem amigos e nem dinheiro. (Comunicante, 24 anos, do lar)

A ausência de formas adequadas de lazer em praticamente todos os bairros de periferia percorridos nesta pesquisa é um problema que apareceu na maioria das 
entrevistas. Trata-se de um sintoma do nivel precário de vida social que raramente encontra condições de ir além do nivel familiar. Neste sentido, o lazer resume-se, principalmente, em ver televisão em família.

O homem encontra mais alternativas que a mulher, na medida em que the é permitido beber com amigos no bar ou jogar futebol, quando é o caso de o bairro ter um campo. O recurso exagerado à bebida - por indivíduos de sexo masculino mostrou-se um problema recorrente para uma proporção em torno de $50 \%$ das famílias entrevistadas. No caso da mulher, a religião e os contatos familiares são, além da televisão, outras fontes disponíveis de lazer.

Eu não saio com minha mulher, porque eu gosto de futebol e ela gosta de outras coisas. Eu gosto muito de cinema, mas se a gente vai ao cinema, nós ficamos sem mistura no domingo. Por isso, o melhor é a televisão. Como eu sou homem, eu sempre encontro tempo para sair com um amigo para tomar

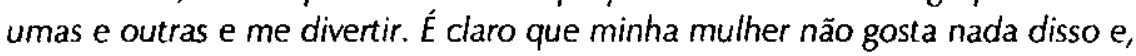
por isso, a gente não vive muito bem. (Comunicante, 34 anos, ajudante de pedreiro)

Nós participamos de um grupo de oraçāo aqui no bairro, que é a nossa única alegria, o nosso único lazer. A gente não sai para mais nada, fora o trabalho e as compras. (Comunicante, 47 anos, faxineira de firma)

O maior problema é a falta de dinheiro. Com o que a gente ganha, mal dá para sobreviver. Nāo dá para comer fora, ir ao cinema ou ter qualquer tipo de diversāo. Qualquer coisa que a gente faça, vai gastar o que não tem e vai fazer falta. (Comunicante, 27 anos, operário)

Lazer, só temos a TV. Às vezes, vou ao baile para dançar, mas só quando tenho dinheiro, dai eu bebo um pouco de cerveja. Quando estou tensa, eu canto e meus filhos cantam junto, isso alivia. (Doente, 33 anos, cozinheira)

O meu marido bebe cerveja demais, ele gasta o que tem e o que não tem, deixando a familia desprovida. Quando ele bebe, ele esquece da vida, inclusive de tomar os remédios para o tratamento de hanseníase. (Comunicante, 40 anos, do lar)

Manter a família (nuclear e extensa) solidária e unida é considerado um valor prioritário, um motivo de orgulho que se pode exibir para qualquer estranho. A solidariedade entre membros da família, inclusive pais e irmãos, é promovida mais significativamente através dos membros femininos que, como se espera, devem cuidar de todos em caso de doença, velhice ou qualquer outra necessidade. Ao promover 
a manutenção de laços sociais que mantêm coesos os membros de uma família, a mulher nutre um componente fundamental como estratégia de sobrevivência física de cada um dos membros do grupo social.

Entretanto, para o homem, esse tipo de cobrança não chega a ser tão forte, sendo a sua responsabilidade para com os filhos, irmãos ou pais sempre menor do que a da mulher. O seu papel social e familiar completa-se como provedor familiar de recursos financeiros. Um bom pai de família e um bom marido são atributos de um homem que cuida para nāo deixar os membros da família sem provisão.

Percebe-se ainda que entre as mulheres, particularmente as mais jovens, há a pretensão de acumular a responsabilidade de contribuir para prover a família financeiramente, sem renunciar à sua responsabilidade estratégica pela manutenção de laços sociais e familiares, pelo menos como um ideal de vida. A proporção das que trabalham fora é significativa (27\%), implicando a dupla jornada de trabalho, uma vez que, via de regra, os serviços domésticos continuam sendo de sua responsabilidade.

Nunca passamos dificuldade que não pudéssemos resolver com a ajuda da família. Tenho nove irmãos e cinco cunhados e, graças a Deus, somos muito unidos. Viemos de Minas, primeiro os homens e, depois que eles arrumaram emprego, as mulheres. Com o tempo, as mulheres também acharam emprego e todo mundo passou a contribuir na despesa da casa. (Comunicante, 31 anos, do lar)

Eu me casei, mas já estou separado porque não deu certo. Os nossos oito filhos moram com a mãe e a cunhada. Eu nāo chego a ajudar porque não dá. Eu gosto dela, mas não deu certo por causa da sogra que queria mandar na minha vida. (Doente, 33 anos, caminhoneiro)

Eu gostaria de trabalhar de faxineira para poder ser livre, mas não dá porque tenho que cuidar da minha mãe doente, como a minha filha terá um dia que cuidar de mim. (Comunicante, 56 anos, do lar)

Depois que casei, nunca mais trabalhei e me ressinto disso. Costaria de ter meu próprio trabalho, de ser mais independente. Mas agora não posso nem pensar em trabalhar, porque, além dos meus filhos, assumi a responsabilidade de cuidar dos filhos de minha irmā. (Comunicante, 31 anos, do lar)

A solidariedade entre vizinhos existe, principalmente entre mães de família, sem chegar a ser expressiva. É possivel encontrar, por exemplo, esquemas não muito comuns para o cuidado de crianças. De um modo geral, a comunidade é percebida negativamente. A dificuldade de se conseguir contatos estáveis no bairro, inclusive 
parceiros sexuais, foi apontada em várias entrevistas. Trata-se de uma condição própria da situação de pobreza urbana no Brasil que se refere ao baixo grau de socialização dos moradores de um bairro. Não há praticamente clubes e as poucas oportunidades de socialização mais consistentes dizem respeito à religião (principalmente seitas protestantes e centros de umbanda). As associaçöes de bairro não chegam a promover eventos num nivel significativo.

A vizinha fica com as crianças enquanto eu trabalho. À noite, eu olho pelos filhos dela enquanto ela estuda. (Doente, 33 anos, cozinheira)

Eu desejo que cada um de nós case com alguém que ama, que tenha a sua própria casa e seja feliz. Hoje em dia, as pessoas estão com o coração muito fechado e não conseguem gostar de ninguém. Por isso, é dificil achar namorado, principalmente aqui no bairro. (Comunicante, 47 anos, faxineira)

O sábado e domingo que tenho que ficar em casa é sempre um transtorno. É marido reclamando, é vizinho que põe o som no último volume, é um amontoado de gente no barraco que sempre me deixa nervosa. Aí eu não vejo a hora de chegar segunda-feira e voltar para o trabalho. (Comunicante, 43 anos, doméstica) 


\section{6}

\section{REPRESENTAÇÕES SOBRE SAÚDE E DOENÇA}

Neste capítulo pretendemos focalizar as representações sociais, tendo em vista as circunstâncias de saúde e de doença. Serão trazidas à tona, entre outras questões, a percepção generalizada da origem multicausal da doença, a importância da integração social e familiar no sucesso terapêutico e a percepção de saúde como diretamente proporcional à capacidade de trabalho. As causas das doenças em geral e da hanseníase em particular e, entre elas, a questão da doença dos nervos merecerão atenção especial.

\section{COSMOLOGIA SOBRE SAÚDE, DOENÇA E HANSENÍASE}

Pensar sobre saúde e doença, no contexto da medicina popular, significa, necessariamente, refletir sobre as causas que promovem um e outro fenômeno. No caso dos grupos amostrais estudados, o problema deixa de ser meramente teórico na medida em que envolve um evento concreto de doença na família. Trata-se ainda de uma doença que significa uma efetiva ameaça à subsistência, uma vez que o seu desenvolvimento implica uma degeneração de nervos que pode impedir o indivíduo de executar muitas atividades físicas exigidas pelo mercado de trabalho. Além disso, a hanseníase é uma doença carregada de significados simbólicos que remetem a uma situação de exclusão e estigma.

É importante lembrar que a rede social para a população trabalhadora no Brasil é, como têm demonstrado várias pesquisas sobre o temạ, ${ }^{1} \mathrm{um}$ instrumento dos mais importantes entre as estratégias de subsistência. $O$ contágio através de um determinado microorganismo é amplamente reconhecido como uma condição importante na doença, mas que não reflete uma causa fundamental. Esta, refere-se quase sempre a um processo de desequilíbrio do indivíduo, seja ele no relacionamento com o próprio corpo, com o seu trabalho ou com o seu meio social e familiar, ao contrário da saúde, que reflete harmonia e equilíbrio nessas esferas.

1 Durhan, E. R. A caminho da cidade. São Paulo: Perspectiva, 1975. 
Quando se considera que, no decorrer da vida, não ocorreram desequilíbrios graves que poderiam ter contribuído para o advento de uma doença qualquer, só então vem à tona a idéia de contágio como um fator plausível. Mesmo assim, este está sempre associado a um estado de debilidade do organismo provocado por um desequilíbrio ou um estresse momentâneo. Quando o indivíduo se considera forte, com boa saúde, ele tende a desdenhar o risco de contágio.

De qualquer modo, como ilustram os trechos de entrevistas abaixo, a doença é percebida como sendo um fenômeno multicausal, que depende não só do microorganismo como também de fatores'socioemocionais que predisponham o organismo a se debilitar e, com isso, permitir o seu desenvolvimento.

Se a gente tiver um contato com alguém que está doente pode pegar uma doença. Mas é preciso que o corpo esteja abalado, enfraquecido, senão a gente estaria doente toda a hora. Por isso, é muito importante não passar nervoso, não beber, não tomar droga. (Comunicante, 51 anos, do lar)

A minha doença pode ter vindo de um internamento no hospital por causa de fratura, pode ter vindo também por ter usado um copo de outra pessoa. Mas se fosse só por isso, muita mais gente pegaria hanseníase. (Doente, 33 anos, motorista de caminhão)

Eu não acredito que nenhuma doença pegue. Tem gente que fala que pega, mas eu não acredito porque eu já vivi com muita gente doente e nunca peguei. (Comunicante, 37 anos, cozinheira)

A unanimidade na crença em fatores multicausais no processo de doença inclui, também, as poucas famílias de classe média e média-alta com um nível melhor de educação. Vale a pena transcrever um trecho da entrevista de um indivíduo com curso superior completo para perceber que, descontada a forma erudita de linguagem, o conteúdo da mensagem se adapta perfeitamente com o do restante dos indivíduos investigados.

Doenças podem ser provenientes de causas genéticas, de exposição a agentes infecciosos, de acidentes e falta de medidas higiênicas. As condições de vida, de trabalho e emocionais também podem levar à doença. Para a manutenção da saúde, a vida deve ser equilibrada entre trabalho, lazer e vida social. O prazer é essencial para se ter saúde. $\mathscr{E}$ possivel que a doença de meu pai tenha sido causada por influências negativas. Se alguém estiver suscetivel a receber esse tipo de influência, poderá ficar perturbado e daí vir a doença. (Comunicante, 28 anos, professor colegial) 
O tratamento de uma doença deve ser realizado de duas maneiras, uma específica, que se refere quase sempre à medicina moderna, aos medicamentos químicos e aos procedimentos hospitalares e outra mais ampla que se refere ao restabelecimento de um equilibrio perdido nem sempre possivel de ser atingido. De um modo geral, acredita-se que o mero tratamento médico, não indo às causas profundas da doença, é um procedimento apenas parcialmente eficaz, uma vez que a situação de desequilíbrio encarregar-se-ia de promover a recorrência da doença. Por esse motivo, a solidariedade social e familiar é considerada indispensável no processo da cura que, para ocorrer, exige cuidados não só do indivíduo doente como de todos com quem ele convive. Entre indivíduos mais idosos provenientes do mundo rural, os sintomas de algumas doenças não são necessariamente vistos como algo negativo, que devam ser interrompidos, mas como parte de um processo de purificação do organismo.

Para tratar e curar a hanseníase, a pessoa precisa de paciência e calma. Se ela for ansiosa e nervosa, aí não tem jeito. Foi assim que agi com meu marido que se tratou direitinho e teve alta em cinco anos. Já a minha irmã nunca teve um ambiente bom com sua família e por isso ela não consegue melhorar. Nāo é possivel um doente se recuperar num ambiente ruim, principalmente no caso da hanseniase que é uma doença dos nervos. Se a pessoa não conseguir ter calma ela não sara. (Comunicante, 74 anos, aposentada)

Quando soube da doença da minha mulher, eu fiquei preocupado, mas sabia que tinha que dar um apoio maior para ela, porque se eu não desse apoio, ela iria piorar por causa do nervoso. (Comunicante, 46 anos, operário)

O meu marido não é nem um pouco nervoso e eu acho que é por isso que ele está sarando. Acho que foi por isso também que nele a hanseníase nāo foi muito grave. Quando a gente está muito atacada, eu acho que a gente pode pegar qualquer doença. (Comunicante, 51 anos, do lar)

Quando a minha filha teve sarampo eu cuidei para que ele não se recoIhesse. Quando a febre vem para fora, a criança fica toda empipocada, mas sara. Quando a febre recolhe a criança pode morrer. Por isso eu não dei nenhum remédio, só alimentei bem e cuidei para que ela ficasse de cama, bem coberta. (Comunicante, 45 anos, do lar)

A doença é necessária porque ela limpa o corpo, o homem precisa adoecer devido aos pecados do corpo. (Comunicante, 66 anos, aposentado, analfabeto) 
Os trechos das entrevistas a seguir irão ilustrar a percepção do trabalho como um elemento fundamental que pode não só trazer saúde e doença como também se constitui num elemento-chave para a definição destas condições. Neste caso, um indivíduo que se vê com disposição para o trabalho tende a considerar-se e a ser considerado saudável, mesmo que esteja acometido de uma doença séria como a hanseníase. É importante lembrar, neste particular, que a incapacidade para o trabaIho significa algo muito sério para famílias que vivem no interior da pobreza e no limiar das possibilidades de sobrevivência. Desse modo, se um indivíduo mostra disposição e capacidade de trabalho, ele é considerado saudável. Apenas num segundo plano a boa aparência e a disposição para sair e passear aparece como um indicador adequado de saúde para indivíduos adultos, embora predomine quando se trata de crianças. Neste sentido, estar doente nāo significa um evento exclusivamente biológico, projetando-se no efeito mais dramático que produz, qual seja, a incapacidade de trabalhar e a conseqüente ameaça à subsistência familiar.

Uma interpretação bastante plausivel para esse fenômeno foi fornecida por Boltanski ${ }^{2}$ ao mostrar que, entre as classes sociais mais baixas, a doença tenderia a ser percebida somente quando houvesse uma incapacitação de performance social, representada especificamente pelo trabalho. Sem surpresa, observamos que esses resultados se repetem em outras pesquisas encontradas em diferentes contextos. ${ }^{3}$ Estes trabalhos demonstram que, entre camadas de trabalhadores manuais, a noçăo de saúde envolve necessariamente integração à sociedade através do cumprimento de tarefas entendidas como obrigatórias. Nesta concepção, a idéia de saúde é alienada do indivíduo e apropriada pelo meio social via capacidade de trabalho, exatamente o contrário do que ocorre entre camadas sociais superiores. As entrevistas abaixo ilustram estes aspectos.

Graças a Deus eu tenho boa saúde. Nunca parei de trabalhar e nunca fiquei de cama. Descobri que tinha hanseníase depois que fiz o teste por causa da doença de minha mãe. Ela foi primeiro e deu positivo, depois fui eu e o teste também foi positivo. Eu nem sabia o que era hanseniase e nunca tinha sentido nada. Eu nem prestava atenção na mancha que eu tinha na perna. Eu sempre me senti muito bem. Agora, com o tratamento, a minha perna incha um pouco e eu não me sinto tão bem. (Doente, 24 anos, ajudante de pedreiro)

2 Boltanski, L. As classes sociais e o corpo, Rio de Janeiro: Graal, 1984.

3 Giovanı, G. A questão dos remédios no Brasil. Sāo Paulo: Polis, 1980.

d'Houtand, A. \& Fieto, M. G. The Image of Health: variations in perception by social class in a French population. In: Sociology of Health and IIIness, v.6., n.1, 1984. 
$V i$ muita gente com hanseniase e com tuberculose no Nordeste. Tinha gente que era uma ferida só. Lá, o doente fica seco, arreganhado; aqui ele é gordo e forte, é como se não estivesse doente. (Comunicante, 66 anos, aposentado)

De um modo geral, como ilustram os trechos das entrevistas a seguir, a saúde é espontaneamente identificada como um estado ideal, que pode se perder no relacionamento do indivíduo com três fatores fundamentais mais amplos.

Em primeiro lugar, acredita-se que o indivíduo tende a adoecer quando passa a conviver com vícios e maus hábitos e negligencia cuidados essenciais ao corpo físico e social. Inserem-se, neste caso, a falta de higiene e o convívio com a bebida, cigarro ou outros agentes tóxicos. O sexo fora do casamento também é visto como uma atividade que predispõe à doença.

De algum modo, atribui-se ao indivíduo em questão uma negligência de ordem moral e, por isso, o fator envolve alguma culpa individual pela doença. O destino, a vontade de Deus ou simplesmente as condições herdadas geneticamente também apareceram com este sentido de culpa, uma vez que no passado o próprio indivíduo ou algum antepassado seu concorreram para causar o problema.

O meu pai morreu porque nunca se cuidou. Ele bebia além da conta, fumava demais e nunca quis seguir os conselhos dos médicos, mesmo depois que ficou doente. Por isso ele adoeceu e morreu cedo. (Comunicante, 43 anos, dona de casa)

Eu acho que a hanseniase, assim como muitas outras doenças, se pega pela relação sexual. Eu só não entendo como peguei porque sou viúvo e não tenho mulher há dez anos. Só pode ter sido dos casos que tive antes do casamento. (Doente, 57 anos, aposentado)

Eu acredito que a doença é uma provação por parte de Deus. O espírito nāo terminou de pagar e a doença vem para saldar alguma falta cometida no passado. (Comunicante, 63 anos, do lar)

A doença pode vir do pecado ou do destino. Veja o caso de uma gestante que vai dar à luz a uma criança, que pode nascer prejudicada se a mãe não tiver os devidos cuidados. (Comunicante, 31 anos, do lar)

Eu acho que peguei essa doença de minha mãe, é genético. Eu nāo me lembro dela, mas pelo que me dizem ela bebia e fazia muita bagunça. Na época, ela morava num cortiço e devia ter muita sujeira, muita coisa ruim. Eu penso que foi daí que começou a surgir a minha doença. (Doente, 33 anos, cozinheira) 
Em segundo lugar, a saúde pode se perder através do meio ambiente mais amplo que foge ao controle do indivíduo e, no entanto, se impóe através de uma má qualidade de vida. Săo exemplos deste caso a alimentaçăo pobre ou insuficiente, a poluiçăo, as condiçōes adversas de trabalho, a falta de recursos médicos e todas as formas de tensão presentes na luta pela sobrevivência em meio urbano. No meio rusal, o obstáculo maior encontra-se no clima, no fato de se ter que trabalhar sob sol e chuva e sob calor e frio.

Este fator encontra no trabalho o elemento fundamental que gera vida, enquanto possibilidade de sobrevivência individual e familiar e, ao mesmo tempo, doença, enquanto produz tensăo e desgaste. Um ambiente de trabalho hostil é percebido como um fator importante de geração de doenças, principalmente para o pobre, que tem que se submeter a um duro trabalho braçal. Além disso, ao contrário do rico, o pobre não pode repor adequadamente as energias perdidas e, por isso, terá que se defrontar mais cedo com a doença. De um modo geral, não se atribui culpa pela sítuação, que é encarada como condição mais ou menos inevitável da vida. Só em algumas poucas ocasióes a culpa recaiu no patrão ou no governo.

O meu marido deve ter pego hanseníase por causa do serviço que ele faz, do entulho que ele mexe e carrega no caminhão. A doença pode ter vindo também das suas viagens, ele vai muito à Bahia e só pode ter trazido de lá, daqui é que ele não pegou. (Comunicante, 43 anos, aposentada)

O meu genro estava trabalhando, um tempinho atrás. Mas pergunta para ele a situação que ele tinha. Não havia nem lugar para esquentar o almoço que ele levava, e a água era de torneira. Foi por isso que ele contraiu hanseníase. (Comunicante, 56 anos, do lar)

A causa da minha doença foi o meu trabalho no sítio, a lavagem que todos os dias tinha que dar para os porcos. Essa lavagem fermentava num balde grande, e eu tinha que tirá-la com as mãos que, por isso, ficavam queimadas. Só pode ser daí que veio esta doença. (Doente, 71 anos, pensionista)

Eu adoeci por causa do trabalho, muito sol, chuva e saco de cimento nas costas. A dormência que começou no corpo foi devido do trabalho duro que eu fazia, do peso que tive que carregar. (Doente, 74 anos, aposentado)

A doença de meu marido começou quando ele trabalhava numa indústria de plástico. Alguma coisa na fábrica deve ter causado a doença. Ele trabaIhava no calor e só pode ter sido por isso. (Comunicante, 28 anos, desempregada) 
Saúde é fácil para o rico e muito difícil para o pobre. A gente sabe que para ter saúde é preciso comer carne, peixe, verdura, fruta, mas a gente só pode comer o que tem no dia e fica faltando vitamina no corpo. Com o tempo vem a doença, não tem como evitar. (Comunicante, 71 anos, do lar)

Um terceiro tipo de fator percebido como causação de doença refere-se à insatisfação com a vida, seja ela social, familiar ou individual. Neste caso, reconhecese que a saúde depende de um estado emocional positivo que, no entanto, algum fator externo pode retirar e confundir o individuo numa síndrome amplamente reconhecida como nervosa, uma condição que se acredita anteceder a maioria das doenças. Esta situação refere-se ao relacionamento humano em geral, que tem a ver com a vida social e familiar e se estende para o trabalho e para as condiçóes mais abrangentes de vida, envolvendo o governo e o País.

O nervosismo é associado às preocupações de toda sorte e às frustraçōes que envolvem tanto as situaçōes particulares de vida restritas à família como as mais gerais, relacionadas com a instabilidade econômica e social. Como seqüela de um relacionamento emocional mal-sucedido, o nervosismo foi reconhecido pela maioria dos indivíduos estudados como fator extremamente importante na causação de doenças. Uma minoria, no entanto, não leva em consideração este fator, ou o leva apenas em circunstâncias especiais, não acreditando que ele possa causar uma doença como a hanseníase.

Alguns indivíduos remeteram-se a um conhecimento difundido no passado de que o nervosismo, produzido pelas agruras da vida, ataca o fígado. Uma vez abalado, este órgão deixa o sangue impuro, acarretando vários tipos de doenças. Este exemplo explicativo reflete uma sintonia com a idéia de interação entre elementos sociais, emocionais e fisiológicos, numa perspectiva holística.

O nervosismo foi apontado por um comunicante de classe média com formação educacional superior, numa única ocasiāo, como uma atitude negativa de responsabilidade individual que acaba por trazer doenças. Em todas as demais situaçōes, o nervosismo apareceu como um fator muito importante na causa de doenças, mas que, como consequeencia natural de condiçōes de vida, de trabalho, social e familiar, encontra-se fora do controle individual.

A nossa sociedade é muito corrupta, a gente ganha pouco dinheiro e vive nervosa, insatisfeita. Isso, sem dúvida, leva à doença, porque a base da saúde é estar de bem consigo mesmo e com a sociedade. Aqui em casa, todos têm algum tipo de problema de saúde, e a causa disso é a insatisfação com o emprego, com a poluiçāo, com a onda de crimes no bairro e até com a corrupçāo que a gente sabe que acontece no governo. (Comunicante, 26 anos, operária) 
O nervoso, além de atacar o fígado e sujar o sangue, deixa o organismo sem defesa. $O$ meu marido tinha hábitos saudáveis, comia bem, nāo fumava nem bebia e às 10 horas da noite já estava na cama. Mas ele tinha problemas no serviço, brigou com um dos fithos e vivia preocupado. Acabou contraindo câncer e morreu disso. (Comunicante, 73 anos, do lar)

Sou muito nervosa, com ataques de nervos freqüentes, principalmente por causa da situação financeira e da falta de dinheiro. O nervoso só pode piorar a hanseníase, já que ela é uma doença dos nervos. (Doente, 48 anos, do lar)

Fiquei doente por causa da falta de paz, da infelicidade no casamento. Quando eu fico nervosa o corpo fica enfraquecido, desgastado, e aí, como a comida de pobre já não tem muita substância, é difícil repor as energias. Quando soube da traição do meu marido com outra mulher, os meus nervos ficaram abalados e a minha doença veio disso. (Doente, 61 anos, faxineira)

Mais uma vez nāo foi possivel notar diferença substancial entre a cosmologia proveniente da população amostral pobre e a dos representantes da classe média. Como pode ser observado no trecho de entrevista abaixo, proveniente de um membro de uma família de classe média, se for descontada a forma de expressão, é fácil perceber que o conteúdo da mensagem não é incompatível com a visão de mundo de indivíduos das classes baixas.

Acredito que o temperamento nervoso e explosivo de meu marido possa tê-lo predisposto a contrair esta doença. Ele é muito introvertido, pessimista e com dificuldade de exteriorizar seus problemas. Ele vive preso em preocupações muitas vezes imaginárias. $\hat{E}$ evidente que este temperamento pode levar à doença, não necessariamente à hanseníase, mas à doença em geral. Eu procuro olhar para o lado bom da vida e desenvolver alguma espiritualidade interior e é lógico que isso ajuda a manter uma boa saúde e afastar as doenças. (Comunicante, 49 anos, do lar, classe média, educação secundária completa) 


\section{REPRESENTAÇÕES SOBRE BENZIMENTO, AUTOMEDICAÇÃO \& MEDICINAS ALTERNATIVAS}

Para os propósitos desta pesquisa, definimos medicina popular como todas as representaçōes e práticas relativas à saúde e à doença que se manifestam independentemente do controle da medicina oficial, ou seja, aquela medicina institucionalizada e regulamentada pelo poder público constituído. É possível encontrar duas áreas distintas onde se manifesta a medicina popular: a medicina caseira, baseada principalmente nas envas medicinais, e a medicina religiosa, baseada principalmente no benzimento. Outras medicinas alternativas - como a osteopatia, a macrobiótica, a acupuntura - não são sequer conhecidas pela população amostral. A homeopatia, no entanto, já foi usada pelo menos uma vez por $25 \%$ das famílias investigadas, sendo, no entanto, um recurso eventual e esporádico.

A medicina caseira e a medicina religiosa são de uso comum e generalizado entre os entrevistados. Apenas duas famílias reportaram não empregar normalmente ervas medicinais; apenas três reportaram que, por princípio, não recorrem e nunca recorreram a benzedores.

Os nossos dados permitem afirmar que o campo da medicina popular está assentado na crença de que a saúde depende, fundamentalmente, de um estado de equilibrio do indivíduo consigo mesmo, com seu meio familiar e social, ao mesmo tempo que a doença depende de um estado de desequilíbrio com essas esferas. Encontrar a causa profunda de uma determinada doença significa, necessariamente, intervir no sentido de restabelecer o equilíbrio perdido.

Não se espera que a medicina oficial moderna possa exercer este papel. Espera-se que ela combata as manifestações próprias da doença, mas se não houver uma intervenção nas causas profundas, no desequilíbrio que permitiu a manifestação da doença, $o$ indivíduo continuaria propenso à recorrência da doença.

Um aspecto importante do desequilíbrio gerado no indivíduo pelo seu meio social mais imediato refere-se à crença de que emoções negativas produzidas contra alguém podem desestabilizá-lo emocionalmente e predispô-lo a contrair doenças. 
Essas emoçóes podem ser emitidas mesmo à distância, ainda que aquele que a recebe nada saiba a respeito. Acredita-se que mulheres e, principalmente, crianças são muito mais suscetíveis de serem vítimas desse tipo de força. Um simples sentimento de inveja, tido como o mais comum de todos os sentimentos negativos, pode ser um exemplo em questão. Quando, além do sentimento, uma prática consistente e continuada baseada na magia é perseguida, o resultado - o feitiço - é muito mais forte e eficaz, podendo trazer doenças e muitos outros males.

Componentes tradicionais como a crença em "quebranto", "mau-olhado"2 e feitiço são amplamente difundidos, e a prática de uso de benzedeiras, particularmente para crianças, é geral entre as famílias pesquisadas, com a exceção de duas de classe média e média-alta que, no entanto, acreditam na base metafísica do fenômeno. O recurso a pai-de-santo é mais restrito, embora ocorra mais generalizadamente como uma esperança para casos mais difíceis.

O recurso a benzedeiras e/ou pais-de-santo como agentes que teriam o poder de restaurar o equilíbrio emocional perdido ocorre, mais freqüentemente, entre mulheres e crianças. Os homens tendem a usar estes agentes apenas em casos graves.

$O$ benzimento apresenta um elemento ambíguo, principalmente quando ele se refere a problemas de adultos e é tratado por agentes ligados a centros espíritas ou de umbanda. Se há um crédito na eficácia do produto, ao mesmo tempo ele é considerado uma força fora de controle dos padrōes morais da sociedade, uma vez que pode se dirigir tanto para o bem como para o mal. Daí o cuidado que se deve tomar na escolha do benzedor. Quando, no entanto, se trata de um caso reconhecido de doença cujo tratamento não tem sido bem-sucedido pelos meios oficiais, ou quando se desconfia de que se está sendo vítima de inveja, mau-olhado ou feitiço, então a procura de benzedores, especialmente pelas mulheres, é freqüente.

Quando o paciente é uma criança, no entanto, o recurso ao benzimento é considerado perfeitamente legítimo e socialmente aceitável. Mesmo os que não acreditam muito na sua eficácia levam seus filhos para benzer, por via das dúvidas e pela pressão social favorável.

No que diz respeito à hanseníase, não se acredita que ela possa ter sido diretamente causada por "mau olhado" ou qualquer sentimento negativo, embora esses sentimentos possam aparecer como coadjuvantes de outras causas. Trata-se de uma interpretação que se aplica a todas as doenças consideradas muito graves. Atribui-se a essas doenças desequilíbrios baseados no modo de vida físico-social - como o tra-

1 Quebranto é um tipo de inveja positiva em relação a crianças. Se alguém olha para uma criança e fica encantada com sua graça e beleza, isso seria capaz de produzir uma série de indisposiçōes. Reconhece-se a existência de quebranto quando uma criança fica manhosa e triste.

2 "Mau-olhado" é uma forma de inveja produzida com um olhar cobiçoso. O sentimento que o acompanha teria o poder de enfraquecer o objeto da cobiça. Se for, por exemplo, uma planta, ela tenderia a definhar; se for a sorte de uma pessoa, ela poderia passar a ter azar e assim por diante. 
balho ou os hábitos alimentares - e não emocional-social - como as indisposições entre vizinhos. Houve, no entanto, quem acreditasse que um bom feitiço teria o poder de trazer esta doença para alguém. Os trechos de entrevistas abaixo revelam estes aspectos:

Eu tenho filhos e levo sempre para benzer porque eles não sabem ainda se defender. Às vezes alguma coisa que outros desejam através da inveja, do quebranto ou mau-olhado pega num inocente. Com malfeito (feitiço) eu não me preocupo. Se a gente trata todo mundo bem, sem distinção, ai é dificil que alguém faça isso. (Comunicante, 31 anos, do lar)

Eu não acredito nem duvido que a minha doença possa ter sido mandada por alguém. Em mau-olhado eu acredito, porque já vi pessoas com esse problema e tinha quem tratasse. Uma vez eu fiquei ruim e o benzimento me ajudou. Eu teria o maior prazer que um pai-de-santo fizesse um milagre e curasse a minha doença. (Doente, 78 anos, do lar)

É muito difícil controlar a inveja que alguém possa ter da gente. O que eu tento fazer é não ligar, porque se liga é pior. De vez em quando, eu vou me benzer. As crianças, eu levo sempre. Só é preciso ter cuidado com quem se benze, porque tem muita gente que lida com macumba. (Comunicante, 25 anos, do lar)

A minha doença deve ter vindo da macumba. Ela veio muito de repente e eu tinha tido uma discussão no serviço. Foi muita coincidência, primeiro elas brigam comigo por causa de questões de trabalho, logo depois vem a doença. A doença veio porque tinha que vir, mas que entrou um pouco de mau-olhado, entrou. (Doente, 61 anos, faxineira de firma)

A medicina religiosa constitui um campo extremamente importante no contexto da medicina popular, produzindo uma cosmologia que inclui noçóes bem definidas de causação de doenças produzidas pelo desequilíbrio do meio social mais imediato ao indivíduo e acrescentando as particularidades de cada religião. Via de regra, o recurso à medicina religiosa não se faz em concorrência com a medicina oficial. A medicina oficial e a popular religiosa são percebidas como complementares, a religiosa contribuindo para que a oficial funcione melhor.

A postura teórica que consideramos mais adequada na análise deste fenômeno é a de Bourdieu ${ }^{3}$ que, num contexto capitalista, percebe o campo religioso como um mercado de bens simbólicos cujo consumo não exige necessariamente um com-

3 Bourdieu, P. A economia das trocas simbólicas. São Paulo: Perspectiva, 1975. 
prometimento ético. Dessa maneira, a religiāo transforma-se em mercadoria que, num sistema competitivo de mercado, é vendida, não em sua totalidade, mas como instrumento parcial para problemas pessoais específicos.

No Brasil, Monteiro ${ }^{4}$ estudou o fenômeno da grande expansão de clientelas flutuantes e transitórias que combinam a eficácia de produtos de empresas de tradições diferentes, senão antagônicas. Como mercadoria, a religião passa a desempenhar um papel utilitário que serve como instrumento para atenuar as aflições da vida urbana. Assim, a clássica função das religiōes, analisada por Weber, ${ }^{5}$ ou seja, a construção de mundos com sentido, é suplantada pela funçăo de controle das incertezas num mundo sem estabilidade, em processo constante de mudança.

As principais instituições religiosas que tratam de problemas de doença em Campinas são o espiritismo kardecista, a umbanda, algumas seitas protestantes como o pentecostalismo, o catolicismo romano e o catolicismo popular. Uma das práticas mais difundidas da medicina religiosa ocorre através do relacionamento com as benzedeiras e benzedores que se utilizam das tradições rituais do catolicismo popular e do espiritismo kardecista para prestar assistência à população.

$O$ recurso às religióes para o tratamento e cura de doenças faz-se, via de regra, sem qualquer comprometimento ideológico. Um doente, por exemplo, pode procurar um pastor ou um pai-de-santo sem ser protestante ou umbandista e sem a pretensão de se converter a essas religiōes. Ao adotar os rituais recomendados por esses agentes, a sua única finalidade é tentar alcançar a magia da cura. Os trechos de entrevistas abaixo demonstram estes aspectos:

Quando eu estava na ignorância, vivia revoltado e achava que a hanseníase tinha sido colocada em mim por um malfeito. Depois que encontrei Deus na lgreja Adventista, eu entendi que a única maneira de me defender é acreditar em jesus que também quer que a gente se trate com a medicina. (Doente, 59 anos, aposentado)

Eu cheguei a ser internado no hospital por causa de dores terriveis na barriga e os médicos me deram alta sem desconfiar que era apendicite. Depois que comecei a freqüentar um terreiro de umbanda, tive que voltar ao hospital e o mesmo médico que antes achou que não era nada, de repente, disse que eu precisava operar do apêndice. Foram as nossas orações que deram um pouco de luz e abriram a mente do médico. Eu operei e nunca mais tive nada. $O$ médico ficou espantado com a facilidade com que tudo correu na operação. $\dot{E}$ claro que sem a operação espiritual tudo teria sido mais difícil. (Doente, 50 anos, motorista aposentado)

4 MONTEIRO, P. Da doença à desordem: a magia na Umbanda. Rio de Janeiro: Graal, 1985.

5 WEBER, M. The sociology of religion. London: Methuen, 1966. 
Não que a gente acredite em pai-de-santo, mas se ouvirmos falar de um que cura a gente leva, porque o importante é sarar. Se o meu marido não sarar com o tratamento médico, então eu vou tratar de convencê-lo a se benzer. (Comunicante, 43 anos, aposentada)

Embora o uso de meios religiosos para obter a cura não entre em conflito com o tratamento médico convencional, em alguns casos excepcionais algum tipo de oposição foi encontrado, inclusive com prejuízo para o tratamento de hanseníase e de outras doenças. Nestes casos, foi possivel observar situações em que o indivíduo simplesmente não crê de todo nas possibilidades abertas pelos meios religiosos ou nas possibilidades abertas pela medicina oficial:

Eu não acredito que religião ajude no tratamento de doenças. A religião consola e a medicina cura. São duas coisas completamente diferentes que não podem ser confundidas. (Comunicante, motorista, 42 anos)

Eu sei que não adianta ir ao médico tratar hanseníase porque a causa disso foi um mau-olhado que uma mulher pôs em mim. Foi por isso que o tratamento para hanseniase que comecei a fazer no Centro de Saúde não deu certo. Eu me sentia muito pior com o tratamento e tive que parar. Hoje, só sinto alivio quando vou a um pai-de-santo que conheço. As coisas que fizeram contra mim demoram para sair do corpo, mas é preciso ter fé. (Doente, 58 anos, lavrador)

O uso de chá caseiro baseado em ervas medicinais ${ }^{6}$ é um instrumento de uso generalizado entre as famílias pesquisadas. Não foi possível encontrar nenhuma delas que, contra algumas indisposiçōes ou mal-estares, deixe de recorrer a esta prática. Trata-se de um meio terapêutico que se encontra profundamente arraigado nas tradições culturais do povo brasileiro e, daí, o seu uso ser encontrado em praticamente todo o território nacional.' As envas são consumidas como parte importante no cuidado doméstico com a saúde e como estratégia empregada, particularmente pela mãe de família, no trato de alguns sintomas e doenças de seus filhos.

Embora no interior rural do País seja possível encontrar especialistas profissionais ("raizeiros") que dão consultas médicas e comercializam os produtos naturais,

6 Termo genérico que compreende várias qualidades de plantas ou partes de plantas, tais como raízes, folhas, troncos de árvore e sementes que săo consideradas como tendo efeito terapêutico quando ingeridas em infusāo. Num plano secundário, elas săo usadas como banhos ou ungüentos para aplicaçāo externa.

7 QuElRoz, M. S. Hot and cold classification in traditional Iguape Medicine. In: Ethnology, 23(1):63-71, Pittsburgh: 1984.

QuE IROZ, M. S. Representaçōes sobre Saúde e Doença. Campinas: Ed. Unicamp, 1990. 
não ocorre na região de Campinas tal tipo de agente, embora existam pessoas entendidas no assunto, o que é o caso das benzedoras, dos pais ou mães-de-santo da umbanda e dos agentes espíritas em geral.

$O$ uso desses elementos obedece a uma lógica baseada no equilíbrio entre as diferentes partes do organismo humano e deste em relação ao meio natural. Neste processo algumas ervas são consideradas quentes e atuam positivamente no sentido de fortalecer o sangue e proteger os pulmões, enquanto outras são consideradas frias $e$ atuam positivamente no sentido de refinar o sangue e proteger o fígado, os intestinos e os rins. ${ }^{8}$ De um modo geral, esta lógica, embora subjacente ao uso de medicamentos, é reconhecida em nível muito mais intuitivo do que intelectual.

A maioria dos que consomem enas medicinais as cultivam no quintal próprio ou as obtêm de vizinhos, e apenas uma minoria as adquire exclusivamente em farmácia, mercado ou feira. As evvas e produtos medicinais mais empregados são o boldo, o poejo, a hortelă, a folha de abacate para problemas do fígado e do intestino, a quebra-pedra para problemas dos rins, o alho e o mel para gripe e resfriado, a camomila para cólica menstrual, a erva cidreira para insônia e problemas nervosos e a erva-doce para problemas estomacais.

A difusão do conhecimento que envolve a medicina caseira ocorre, via de regra, através de pessoas mais velhas na família, geralmente via sexo feminino, embora o sexo masculino não esteja excluído. $O$ espiritismo kardecista $e$, mais modernamente, a umbanda são também importantes difusores de ervas medicinais e das formas terapêuticas que elas envolvem.

Em princípio, o uso de ervas medicinais ocorre sem nenhum antagonismo com a lógica da medicina moderna oficial. Normalmente, este uso ocorre para os diversos mal-estares ou indisposiçōes, os quais são avaliados como problemas menores que não merecem a preocupação ou o cuidado médico. Apenas quando o problema é considerado mais grave é que se recorre a agentes farmacêuticos e médicos. Em algumas ocasiōes, as ervas medicinais são acrescentadas aos medicamentos químicos receitados pelos médicos, sem que seja observada qualquer contradição neste processo.

A razão da persistência desses medicamentos num contexto capitalista relativamente desenvolvido é que eles, até certo ponto, complementam os vazios deixados pela medicina oficial como, por exemplo, os mal-estares e indisposições considerados não graves, ou algumas doenças crônicas, as quais os médicos previdenciários ou os de Postos de Saúde deixam de medicar. Os trechos de entrevistas abaixo revelam estes aspectos:

8 Queiroz, M. S. Hot and cold classification in Traditional Iguape Medicine. In: Ethnology, 23(1):63-71, Pittsburgh, 1984. 
Quando meus filhos estão agitados, eu dou erva cidreira ou hortelã. Eu acredito em chás, mas só para problemas menores, não como meus pais usavam que servia para tudo e era um exagero. (Comunicante, 31 anos, do lar)

Eu aprendi sobre o uso de chá com os mais velhos; fui crescendo e aprendendo vendo os mais velhos fazerem. A māe é praticamente obrigada a aprender quando tem filhos. (Doente, 36 anos, empregada doméstica)

A gente tomava muito chá no tempo do sítio. Para qualquer mal havia uma enva e a gente tomava porque não havia médico. Hoje, a gente toma só para problemas menores. (Doente, 40 anos, pequeno empresário)

Em algumas ocasiões, como dimensionam os trechos de entrevistas abaixo, foi observada oposição entre a medicina popular caseira e a medicina oficial. Esta oposição, no entanto, não se manifesta com frequêencia na prática, embora esteja sempre presente de um modo latente num plano ideológico. Uma interpretação plausível para este fato é que o caráter intervencionista e sintomático da medicina moderna oficial contradiz a idéia de equilíbrio presente na medicina popular caseira. Esta contradição é reconhecida pelas representações dos indivíduos, embora, em seu exercício, a força de penetração da medicina oficial não permita a possibilidade de competição entre os respectivos sistemas. Excepcionalmente, no entanto, há indivíduos que optam exclusivamente por tratamentos naturais baseados em dietas, ervas ou medicamentos homeopáticos. A demora na obtenção de atenção médica que se verifica no Centro de Saúde concorre para reforçar esta opção:

Às vezes, ao invés de ir ao médico, eu pego todos os remédios do mato, coloco no álcool, ponho ainda remédio para dor e sal, bato tudo, fervo e tomo. Eu já estou velha mesmo e faço do jeito que eu gosto. A última vez que eu fiz, Deus ajudou e eu melhorei do meu reumatismo. (Comunicante, 57 anos, do lar)

Um dia, eu fiquei tão desanimado com a demora no atendimento no Centro de Saúde que larguei tudo lá, remédio, consulta e cartão para nunca mais voltar. Hoje, quando me sinto mal, procuro um pai-de-santo que me recomenda várias ervas medicinais que nunca atacam o corpo. Eu prefiro o jeito de Deus. (Doente, 58 anos, lavrador)

Já tive tuberculose e me curei com ervas caseiras. No começo eu me tratei com um médico que me entuchou de vários remédios que me faziam ficar muito pior do que estava. Um dia eu criei coragem e joguei todos eles fora e, a partir desse dia, comecei a fazer tratamento por minha conta. Passei a tomar 
sumo de saiăo com leite, sumo de evva Santa Maria e fiz uma garrafada com acapê e erva de passarinho. Em poucos meses já me sentia muito melhor e acabei sarando dessa doença. Foi a melhor coisa que fiz. (Doente, 71 anos, pensionista) 


\section{DIAGNÓSTICO, TRATAMENTO E AVALIAÇÃO DO SERVIÇO}

Os depoimentos relativos à história pessoal do desenvolvimento dos sintomas, do recurso a médicos e do diagnóstico da hanseníase apresentam um ponto em comum, qual seja, na maioria dos casos (cerca de $90 \%$ ), antes de haver o diagnóstico da doença, o paciente passou por um médico que emitiu um diagnóstico errado. A situação mais comum, no entanto, envolveu vários médicos e muitos anos de tratamento equivocado. Esses depoimentos são eloqüentes no sentido de revelar um fato que é amplamente reconhecido pelos profissionais especializados em hanseníase no Centro de Saúde I (Policlínica) em Campinas e pelos demais especialistas entrevistados nesta pesquisa, ou seja, os médicos, de um modo geral, receberam treinamento insuficiente para lidar com várias doenças endêmicas no Brasil. Quando se pensa em hanseníase, esta deficiência revela-se de um modo ainda mais pronunciado, a ponto de haver uma profunda ignorância no que diz respeito a esta doença. Este fator concorre decisivamente para que a hanseníase seja, quase sempre, diagnosticada tardiamente. Além destes aspectos, este capítulo mostrará também o relacionamento dos doentes com o tratamento, com o diagnóstico e com o serviço médico. O significado que assumem os nomes 'lepra' e 'hanseníase' e a avaliação do serviço e da medicina oficial serăo também focalizados. Inicialmente, no entanto, temos trechos de entrevistas que demonstram o problema do diagnóstico equivocado:

A minha avó ficou por mais de 10 anos fazendo um tratamento que não tinha nada a ver com hanseníase porque os médicos achavam que era primeiro reumatismo e depois diabetes. Quando ela voltou a Campinas eu a levei ao posto de saúde e só então o médico suspeitou que ela poderia ter hanseníase e a mandou ao Centro de Saúde. (Comunicante, 37 anos, cozinheira) 
A minha doença começou com uns caroços no corpo há cinco anos. Eu me tratei com um médico que me encheu de remédios que não fizeram qualquer efeito, só me intoxicaram. Cheguei a me internar no Hospital e um grupo de estudantes ficou em cima de mim, sem descobrir a minha doença. Se não fosse a minha mulher suspeitar que poderia ser hanseniase, provavelmente eu ainda estaria nas mãos de médicos que não conhecem nada dessa doença. Eu levei a suspeita da minha mulher para o médico que resolveu me encaminhar para o Centro de Saúde. (Doente, 50 anos, motorista de ônibus aposentado)

Apareceu uma mancha na perna, mas eu achava que era por causa da intoxicação de umas injeçōes de antibiótico que tinha tomado e não me preocupei. O tempo foi passando e um dia acordei com as pernas totalmente adormecidas e mal consegui me levantar da cama. Nessa ocasião, torci o pé esquerdo que inchou e foi engessado. Quando o gesso foi retirado, o médico constatou que o pé continuava inchado. A partir dai eu fui a vários outros médicos, o pé foi engessado de novo e só depois que uma médica percebeu que, além do inchaço havia insensibilidade no braço é que decidiu me encaminhar para o Centro de Saúde. (Doente, 61 anos, faxineira de firma)

O reconhecimento dos sintomas da hanseníase depende de dois fatores. Primeiro, da percepção de algo anormal no corpo e, segundo, de um conhecimento que remeta esta percepção a uma situação de doença. No caso da hanseníase, a junção desses dois fatores é difícil de ocorrer uma vez que, como muito bem demonstrou Boltanski, ${ }^{1}$ a percepção de um sintoma corporal depende em grande medida de referência simbólica que o situe no interior de um determinado sistema cosmológico. Só então este sintoma poderia ser reconhecido, classificado e lidado apropriadamente.

A palavra desempenha um papel dos mais importantes neste processo e nela já se inclui uma série de atitudes, valores e estratégias de ação. Como, no entanto, o capital taxonômico das classes trabalhadoras manuais é pequeno com relaçăo a eventos corporais, a percepção destes fica prejudicada, a não ser quando o sintoma evolui para formas significativas de dor ou incômodo.

No caso da hanseníase, esta situação pode ser ainda mais dramática, uma vez que os sintomas, no início da doença, não são muito notáveis e nem prejudicam o desempenho no trabalho. Por esse motivo, também porque, praticamente, não existe uma busca planejada de casos desta doença por parte de um programa de saúde pública, a procura por tratamento é freqüentemente tardia. Esta situação torna-se ainda mais grave quando nos deparamos com a ignorância de uma ampla proporção de médicos sobre a doença.

BOLTANSKI, L. As classes sociais e o corpo. Rio de Janeiro: Graal, 1984. 
Uma dimensão importante da hanseníase é que ela é uma doença que, em suas formas mais evoluídas, pode causar lesões de nervos e impedir a execução de muitas formas de trabalho. Nos grupos amostrais estudados, grande parte dos indivíduos conhece este fato e o leva em conta na decisão de continuar e persistir com o tratamento. A idéia de não mais poder trabalhar significa uma ameaça direta à subsistência e, portanto, algo realmente grave na vida de cada um:

Eu não sabia nada sobre a hanseníase, só depois que começou o tratamento eles explicaram e eu aprendi. Muitas coisas próprias da doença, tais como insensibilidade e coceira na perna, eu nem notava e hoje eu estou sempre ligado nisso porque é preciso passar um óleo que os médicos recomendam. (Doente, 40 anos, pequeno empresário)

Só quando perdi o movimento do dedinho da mão esquerda e o pé passou a só virar para baixo é que eu procurei tratamento médico. (Doente, 40 anos, pequeno empresário)

Eu só recomecei o tratamento há quatro meses depois que percebi que estava ficando pior e não estava dando conta do serviço de casa. (Doente, 62 anos, dona de casa)

Embora a preocupação com o uso do corpo no trabalho seja crucial para a subsistência da grande maioria dos entrevistados, e a hanseníase envolva uma ameaça a este aspecto, houve uns poucos indivíduos que demonstraram não se importar com isso. Eles preferiram interromper o tratamento e se colocar sob o risco de se verem impedidos de exercer o seu trabalho a continuar se submetendo às recomendações médicas. A alegação dos quatro entrevistados que se encaixam neste caso foi que o trabalho os impedia de permanecer na fila de espera para receber atenção no Centro de Saúde todo mês. Observa-se, nessas situaçōes, que a perspectiva de planejamento a curtíssimo prazo, que corresponde à quase totalidade das açōes postas em prática ao longo de suas vidas, foi mais consistente do que o medo projetado no futuro a exigir uma disciplina a longo prazo.

Faz um ano que comecei a me tratar de hanseníase e faz seis meses que interrompi o tratamento. Já recebi cartas do Centro de Saúde pedindo para voltar, mas eu não posso perder tempo de trabalho esperando ser atendido. (Doente, 29 anos vendedor ambulante)

Como vimos anteriormente, o tratamento da hanseníase é difícil e demorado. Ele exige um tempo médio de dois anos no caso de o paciente estar se submetendo à poliquimioterapia (PQT). Mesmo a forma mais branda da hanseníase (a paucibaci- 
lar) exige um tempo mínimo de seis meses. No caso do tratamento tradicional, o tempo é muito maior, podendo chegar a quinze ou mais anos, dependendo da evolução do paciente.

Em princípio, a PQT, por ser mais eficaz e por ter uma duração muito menor, é mais desejada tanto pelos médicos como pelos pacientes. Porém, ela não é tolerada por alguns pacientes que, por apresentarem efeitos colaterais fortes, não oferecem alternativa ao tratamento tradicional. Um dos efeitos colaterais, amplamente reconhecido como muito desagradável é, como vimos, o escurecimento da pele. Outros efeitos referem-se a indisposições estomacais, prejuízo para o funcionamento dos rins e indisposição geral para o exercício de atividades físicas e mentais.

Além dos antibióticos, o tratamento demanda uma disciplina que altera muitos hábitos do paciente, exigindo abstinência de bebidas alcoólicas e exercícios físicos diários para os tendões e filamentos nervosos, principalmente dos membros superiores (braços, mãos e dedos) e inferiores (pernas, pés e dedos). Os antibióticos săo fornecidos gratuitamente pelo Centro de Saúde que acompanha a evolução do tratamento, exigindo a presença mensal do paciente.

De um modo geral, foi possivel observar que a grande maioria dos pacientes não segue adequadamente $o$ tratamento, particularmente no que se refere aos exercícios físicos. Apenas uma minoria confirmou segui-los de um modo rigoroso. Quanto ao uso dos antibióticos, a maioria segue o tratamento, apesar do mal-estar que eles provocam. Uma percentagem significativa (20\%) interrompe momentaneamente o consumo de medicamentos quando o mal-estar decorrente do seu uso torna-se insuportável. A abstinência ao uso de bebida alcoólica é, no entanto, um fato que está longe de ser geral.

A proporção dos que fazem corretamente os exercícios necessários para a recuperação da mobilidade das mãos e pés é muito pequena (cerca de 15\%). Como ilustram os trechos e entrevistas abaixo, os exercícios físicos mostraram-se incompativeis para quem trabalha com o corpo o dia inteiro e chega cansado em casa:

A enfermeira me orientou para por os pés na água quente, massagear a perna com óleo e fazer exercícios para os nervos, mas raramente eu faço tudo isso. A gente esquece. Ela recomendou para usar um barbantinho no dedo para não esquecer, mas a gente esquece do barbantinho também. (Doente, 33 anos, operário)

Eu não faço nenhum dos exercícios que me recomendaram no Centro de Saúde porque não entendi bem o que era para fazer. Eu me exercito capinando nos lotes e já é exercício suficiente. (Doente, 52 anos, autônomo)

Eu tomo todos os remédios recomendados, mas fora de hora. Eu nāo consigo encontrar tempo para fazer os exercícios e nem evitar de tomar sol por 
causa de meu trabalho como motorista de caminhão. (Doente, 33 anos, motorista de caminhão)

O nome hanseníase foi dado à lepra numa tentativa de reduzir o estigma associado com esta doença. Nem todos os países adotam esta nomenclatura. No Brasil, a decisão de adotá-la ocorreu num contexto em que uma nova atitude para com a doença foi tomada pelas áreas competentes de saúde pública, em particular o Ministério da Saúde e as Secretarias Estaduais de Saúde.

O fato é que esta mudança de nome concorre positivamente para se considerar a hanseníase como uma doença como outra qualquer, reduzindo a conotação negativa associada ao nome lepra. Cerca de $50 \%$ dos indivíduos entrevistados não consideram que hanseníase e lepra sāo a mesma doença, ou consideram ambas como estágios muito diferentes da mesma doença, onde a lepra aparece como uma manifestação muito mais grave.

Uma outra direção importante transmitida pelo Centro de Saúde aos pacientes refere-se a uma certa banalização da hanseníase como sendo uma doença que, por ser curável, não apresenta muitos riscos quando tratada. Juntamente com este aspecto, inculca-se no paciente a crença de que não há qualquer outra forma de tratamento possível para esta doença. Para que ocorra a cura, o paciente tem que se submeter incondicionalmente ao tratamento prescrito, principalmente no que se refere ao uso de antibióticos:

A palavra lepra assusta muita gente, mas já tem cura. Assusta porque vem da tradição, as pessoas mais velhas não tinham conhecimento nenhum, eram ignorantes. Ouviam aquilo e se horrorizavam. Hoje a sociedade é mais esclarecida. Quando a minha irmã me contou que tinha esta doença eu não tive reação estranha nāo. Ficou bem claro que a gente não devia se preocupar. (Comunicante, 31 anos, do lar)

Quando o meu marido foi diagnosticado como hanseniano, em 1959, o preconceito foi uma coisa de doido. Nāo se podia falar sobre o assunto porque todo mundo tinha medo. Os que sabiam da doença dele não davam a mão e evitavam chegar perto. Hoje é diferente, eu conto para todo mundo esse problema e não percebo nem medo nem preconceito. (Comunicante, 74 anos, aposentada)

Eu não sei o que é lepra, já ouvi falar que é uma doença muito ruim que dá feridas cascudas que arrebentam na pele deixando a pessoa suja e fedida. Graças a Deus eu nunca vi esta doença. Hanseníase é o que eu tenho, começa com um formigamento na pele e depois a gente não sente nada naquela parte. Não dá para explicar muita coisa, o motivo da doença, como ela acontece, es- 
sas coisas, por que a gente não pensa muito no assunto. Para explicar bem, a gente teria que estudar em livro. (Doente, 62 anos, dona de casa)

Quando soube que tinha esta doença, me senti muito humilhada. Eu cheguei a discutir com o médico e com as enfermeiras porque não era possível achar que eu tinha uma coisa dessas. Mais tarde, entendi que a hanseniase é uma doença como outra qualquer. (Doente, 71 anos, pensionista)

O conhecimento sobre a hanseníase pelos indivíduos pesquisados é rudimentar, como a compreende a ciência ocidental moderna. Uma proporção significativa dos comunicantes e dos pacientes (25\%) tem uma visão distorcida ou não sabe praticamente nada sobre a doença, enquanto os demais sabem apenas rudimentos que, no máximo, são equivalentes aos cartazes informativos no Centro de Saúde.

Via de regra, esses conhecimentos se aplicam exclusivamente ao caso pessoal do indivíduo doente na família. Em alguns casos, o comunicante sequer sabia que havia um doente de hanseníase em sua casa. Quanto aos medicamentos ingeridos, a maioria dos pacientes e dos comunicantes entrevistados sabiam muito pouco sobre o seu modo de ação.

A representaçăo mais comum para a hanseníase refere-se a uma situação de ambiguidade. Se por um lado, ela aparece como uma doença que tem cura, que, se tratada, năo contamina, ainda assim ela é considerada como merecedora de preocupaçāo. Quando se consideram outras doenças graves tais como o câncer ou, particularmente, a AIDS (uma referência constante para situar positivamente a hanseníase), então a hanseníase volta a ser considerada uma doença banal:

Eu não tenho a mínima idéia do que seja hanseníase porque é a primeira vez que estou ouvindo. Lepra eu já ouvi falar, parece que é uma doença grave, a pessoa fica deformada, é muito contagiosa e por isso a pessoa tem que ficar separada. Mas a gente não entende, não sei dar uma explicação. Eu nunca vi esta doença e nunca conversei sobre isso antes. (Comunicante, 34 anos, doméstica)

Como seres mortais, estamos sujeitos a contrair qualquer doença, inclusive as mais sérias. Ainda bem que a hanseniase tem cura. Duro seria você estar com uma doença sem tratamento. Muito pior do que a hanseniase é o câncer e, ainda pior do que o câncer é a AlDS. Essas doenças causam um enorme sofrimento e o fim é sempre a morte. Com a hanseniase, o sofrimento é muito menor. (Comunicante, 39 anos, escriturária)

Nunca quis saber sobre a doença da minha sogra; nunca perguntei porque acho chato. Se a pessoa não conta, a gente não deve ficar especulando. 
Separar a pessoa doente seria muito ruim para ela e isso a gente não faz, mesmo porque a hanseníase não é uma doença contagiosa; se fosse, alguém de nós já estaria contaminado. (Comunicante, 29 anos, pedreiro)

Quando comecei a fazer os exames no Centro de Saúde, eu tinha medo que fosse AIDS. A médica fez muitos mistérios antes de me dizer o que eu tinha e eu fiquei muito assustado. Quando soube que tinha hanseníase me senti até melhor. Os médicos me explicaram que, fazendo o tratamento, a doença deixaria de ser contagiosa. Acho que serei curado e não estou preocupado. (Doente, 40 anos, pequeno empresário)

A maioria dos indivíduos estudados (82\%) avaliou negativamente o governo do tempo da época que antecedeu o levantamento de dados da pesquisa, o Governo Collor, identificando-o com a difícil situação de vida e de trabalho. Esta avaliação coincide com o momento extremamente grave de crise econômica, social e cultural por que passa o País. A inflação em torno de $20 \%$ ao mês atinge principalmente os trabalhadores que não têm como dela se defender. Os serviços públicos deteriorados, o desemprego e o aumento impressionante da criminalidade, todos esses fatores repercutem, principalmente, na população trabalhadora residente na periferia urbana. As políticas públicas, ou a ausência delas, excluem, de um modo ou de outro, os pobres nos campos ocupacional, educacional, habitacional e político. Os indivíduos pesquisados percebem isso claramente e consideram uma conseqüência natural que o pobre adoeça mais do que o rico.

A oferta de serviços de saúde "oficial" disponivel compreende fundamentalmente a rede básica de serviços públicos de saúde, os farmacêuticos, a medicina conveniada e a medicina privada, envolvendo agentes tais como médicos, enfermeiras, atendentes de enfermagem e práticos de farmácia.

A medicina conveniada é promovida pelas grandes firmas aos seus funcionários e a suas famílias, recebendo da comunidade uma avaliação bastante positiva. A medicina particular, através de consulta privada, embora receba aprovação inquestionável da comunidade, é um recurso que, pelo seu custo financeiro, torna-se excepcional. $O$ recurso ao farmacêutico como agente de diagnóstico e cura de doenças é também comum, constituindo parte importante nas estratégias de consumo de medicamentos por parte dos indivíduos estudados. ${ }^{2}$

No que se refere aos serviços públicos de saúde, $38 \%$ da população amostral os considera precário e insuficiente; $44 \%$ o considera aceitável, com restrições, e apenas $18 \%$ o considera adequado. Os hospitais universitários receberam uma avaliação mais favorável dos indivíduos estudados do que os Postos e Centros de Saúde.

2 Ver, a respeito, QueIRoz, M. S. Representaçōes sobre Saúde e Doença - agentes de cura e pacientes no contexto do SUDS. Campinas: Ed. UNICAMP, 1990. 
Considera-se que, neles, não só o atendimento é mais rápido, mas também melhor. A possibilidade de receber um serviço com maior disponibilidade de meios diagnósticos e terapêuticos que se supõe haver nestes hospitais concorre para esta avaliação positiva.

A insatisfação da clientela com os senviços prestados pela rede pública de saúde tem a ver, principalmente, com a demora no atendimento e com a expectativa frustrada a respeito do tratamento médico. A tendência de alguns médicos da rede pública de não medicar desnecessariamente o paciente tem como efeito gerar descontentamento:

A situação do país está péssima. Não há emprego, muitos dos meus colegas mais antigos viraram bandidos. Tem muito pivete nas ruas, trombadinhas que roubam por vicio, para comprar droga. A gente que procura viver honestamente, sofre, não encontra oportunidade. $O$ Collor acabou de estragar o País. (Doente, 26 anos, ajudante de pedreiro)

O pecado que eu cometi por ter esta doença é ter nascido no Brasil. Se fosse em outro país as condições seriam muito melhores. Aqui, quando a gente precisa de um tratamento, dá muito trabalho e tudo é muito difícil. Quando precisa de um exame, a demora é de pelo menos três meses. O governo precisaria dar mais apoio para a saúde. Todos nós merecemos que esse desejo seja atendido, mas atualmente isso parece ser impossivel. (Doente, 40 anos, pequeno empresário)

Os médicos do Posto fazem pouco da gente. Eles acham que o que é descontado do seu salário e vai para eles é muito pouco e você não recebe um tratamento adequado. A pobreza inteira está lá e eles não dão conta e, então, eles dão um remedinho só para aliviar. A gente consegue isso depois de ter ido não sei quantas vezes para marcar consulta e esperar um bom tempo na fila. Daí a gente fica mais nervosa e mais doente ainda do que estava. Pior ainda quando encontra um médico que trata mal o cliente. Por enfrentar todos esses problemas é que o pobre é mais doente do que o rico. (Doente, 61 anos, faxineira de firma)

Eu fico muito irritada quando vou ao Posto de Saúde para mim ou para meus filhos e ouço o médico dizer sem nem examinar ou pedir exames clínicos que a gente nāo tem nada de errado. Aí a gente volta frustrado porque continua com o problema sem ser medicado. Quando isso acontece, eu procuro outro médico ou o farmacêutico já conhecido da gente. (Comunicante, 29 anos, do lar) 
Quando a atenção é focalizada especificamente no Centro de Saúde que promove o tratamento para a hanseníase, a avaliaçāo dos indivíduos pesquisados é melhor do que a do sistema de saúde em geral, chegando a ser positiva em cerca de $29 \%$ dos casos. Os que avaliaram o serviço como adequado, com restriçōes, chegam a $43 \%$ e os que o consideraram precário e insuficiente totalizam $28 \%$.

Os que espontaneamente avaliaram positivamente o serviço deram como razão principal o fato de o serviço ser grátis e o seu custo ser maior do que a contribuição que eles dão em forma de imposto. Foi também bastante mencionada a qualidade no atendimento, principalmente de um ou outro médico ou enfermeira. Quando, no entanto, o entrevistador destacou as principais falhas do serviço, a tendência foi concordar que elas de fato existem.

As maiores restriçōes ao serviço foram, pela ordem de importância, a demora no atendimento, a falta de esclarecimento e comunicação para com os doentes e a falta de atenção de médicos e pessoal de enfermagem por problema de falta de tempo. Estas condiçōes concordam plenamente com a avaliação do serviço realizada pelos médicos e pessoal de enfermagem do Centro de Saúde. Os trechos de entrevistas abaixo revelam como estes aspectos são representados:

Eu já melhorei uns $80 \%$ depois que comecei a fazer o tratamento. Não tenho nenhuma queixa de lá, todos me tratam muito bem. O serviço é nota dez. Quando eu sarar, pretendo voltar lá de vez em quando para fazer uma visitinha. (Doente, 50 anos, motorista aposentado)

Os médicos e as enfermeiras que trabalham com hanseniase têm um salário muito baixo, então tem aqueles que tratam a gente com carinho e aqueles que atendem a gente muito mal, que descarregam os seus problemas em cima da gente. (Doente, 33 anos, operário)

Sempre fui bem atendido no Centro de Saúde. O único problema é a mudança freqüente de médicos. A demora para ser atendido, para mim, não é problema porque meu patrão sabe da minha doença e é compreensivo, deixando eu me atrasar no serviço quando vou ao Centro de Saúde. (Doente, 41 anos, autônomo)

$O$ atendimento no Centro de Saúde é muito ruim, muita demora e tudo muito mal explicado. Eu não consegui entender muito do que foi ensinado sobre a doença e sobre os exercícios. Antes de me tratar lá, eu me tratava no hospital Mario Gatti e tomava um remédio para a circulação por causa do formigamento na perna. Até hoje eu não tenho certeza se de fato eu tenho hanseníase, pode ser que o primeiro médico tivesse razão e eu tenho problema de circulação ou de alergia. (Doente, 74 anos, aposentado) 
O problema da dificuldade de comunicação entre equipe de saúde e paciente merece um destaque entre os obstáculos apontados pelos indivíduos pesquisados. Considerado como o segundo maior problema no Centro de Saúde, a falta de informações a respeito da hanseníase aparece como uma aflição constante entre os indivíduos pesquisados. Nota-se, neste particular, que há uma forte demanda reprimida com relação a um melhor conhecimento sobre a doença, sobre o processo de transmissão e sobre a obtenção da cura. Entre alguns pacientes pairam dúvidas sobre se de fato estão com hanseníase pois, afinal, outros médicos deram outros diagnósticos e eles podem ter razão. Outras dúvidas dizem respeito a se, realmente, a doença tem cura, ao tempo de tratamento e aos exercícios, dietas e procedimentos necessários. Ficou claro nas entrevistas que a falta de esclarecimentos prejudica de um modo significativo o tratamento da doença.

Nesse contexto, os entrevistadores tiveram alguma dificuldade para se desvencilhar do assédio que muitos entrevistados realizavam no sentido de obter várias informaçōes a respeito da doença. Como mencionado no primeiro capítulo do livro, ainda que a principal entrevistadora fosse uma enfermeira com especialização em hanseníase, o procedimento foi invariavelmente recusar qualquer explicação para não prejudicar $o$ andamento das entrevistas.

Uma proporção significativa dos indivíduos entrevistados considera que o governo deveria explicar melhor sobre a hanseníase em programas de televisão, veículo de comunicação mais acessivel para a população trabalhadora:

Eu acho que a gente deveria estar mais a par de problemas de saúde. Por que não se dá mais esclarecimento e informação para o povo na $T V$ já que todo mundo vê $T V$ ? Só assim o povo teria mais esclarecimento, mais informação e saberia se prevenir da doença. (Comunicante, 37 anos, ajudante de pedreiro)

Eu gostaria de saber muito mais do que sei sobre a hanseníase, como ela reage na gente, se vai mesmo ter cura, como ela passa para outra pessoa. Se tivesse esperança de que iria sarar eu poderia assumir certos compromissos com minha namorada que não sabe nada sobre a minha doença. É duro saber que alguém pegou uma doença grave por sua causa. Eu não tenho a menor idéia de como as pessoas que moram comigo teriam que fazer para não pegar a doença. (Doente, 24 anos, ajudante de pedreiro)

Eu não estou bem esclarecida sobre a hanseniase. Costaria de saber mais sobre como a doença é transmitida, como se desenvolve. Eles me explicaram tudo isso, mas a gente não entende bem. Eu tento pesquisar nos cartazes que têm no Centro de Saúde, mas ainda tem muita coisa que eu não sei. Por isso, eu desanimei e não faço os exercícios. (Doente, 36 anos, empregada doméstica) 
O Centro de Saúde dá um bom atendimento, os médicos e as enfermeiras são atenciosos, eu só acho que eles poderiam explicar melhor sobre a hanseníase, como a doença aparece, como se pega. Eu tive uma entrevista com uma enfermeira que deu explicação, mas já faz oito meses e eu esqueci tudo. (Doente, 55 anos, aposentado)

Deveria haver um serviço mais eficiente de informação sobre a hanseníase. Acho que falta um trabalho educativo de esclarecimento público sobre a doença. É preciso passar informaçōes básicas sobre a doença, porque muito pouca gente a conhece. Mesmo os médicos não a conhecem. Não gosto do serviço do Centro de Saúde. (Ex-doente, 53 anos, técnico em prótese dentária)

O processo de avaliação de um serviço público apresenta um forte componente de subjetividade que mesmo uma pesquisa qualitativa, algumas vezes, não consegue controlar. Em pelo menos uma ocasiāo, a ambigüidade da avaliação foi óbvia. O paciente considerou excelente o serviço, mas interrompeu o tratamento porque decidiu que não houve acerto para com o seu caso específico.

Esta maneira de pensar e agir, embora tenha aparecido em apenas uma única ocasião de forma explicita, é de fato comum. Avalia-se a pessoa do médico enquanto um ser humano, sem que ocorra uma dissociação com sua competência profissional. Neste caso, não se considera de inteira responsabilidade do médico se ele errar o medicamento para um determinado caso. Não se espera que o médico acerte sempre e não the é atribuída nenhuma culpa neste processo. Cabe ao paciente procurar outro médico e, com ele, tentar uma melhor sorte.

Os trechos de entrevistas abaixo ilustram esta maneira pontual de ver o problema, que corresponde à causa da maioria das interrupções do tratamento de hanseníase. Ser um bom médico, segundo esta representação, mais do que "acertar" os remédios, significa ser atencioso e conseguir estabelecer uma conexão emocional para com o paciente. Considera-se, inclusive, que essa conexão emocional facilita muito o acerto médico. Neste sentido, o hospital é visto como um ambiente que, embora tecnicamente necessário para o tratamento, é frio e pode trazer outros agravos à saúde:

Os médicos do Centro de Saúde são bons, eles só não acertaram os remédios comigo. Por isso é que interrompi o tratamento de hanseníase. (Doente, 24 anos, contínuo de firma)

$O$ pessoal que trabalha com a hanseniase deve ser um profissional com experiência, mas se ele nāo tiver muita paciência, o seu saber nāo adianta 
nada. É importante ele não ter dúvida, transmitir segurança e calma e responder às dúvidas com simpatia. (Doente, 40 anos, pequeno empresário)

Ser atendida com atenção e carinho é o que a gente espera de um serviço de saúde. A gente vai lá nervosa, cheia de problema e se não for bem recebida é pior do que se não tivesse ido. (Doente, 61 anos, faxineira)

Quando eu vou ao Centro de Saúde eu faço questão de ser atendida pelo Dr. "C". Ele acertou o tratamento e eu me dou muito bem com ele. Fu prefiro ter que esperar mais tempo ou mesmo voltar outro dia do que ser atendida por um outro médico em quem eu não tenho confiança. Se não há confiança, é difícil o tratamento dar certo. (Doente, funcionária pública, 43 anos)

Eu não gosto de internamento. Não gosto de hospital, acho uma tristeza, mas se não tem jeito, tem que ir, tem que tratar. Quando meu pai ficou internado, foi uma tristeza vê-lo na mão dos outros. Tudo lá é muito frio e, por isso, eu fiquei muito preocupada. (Comunicante, 51 anos, do lar) 


\section{RELACIONAMENTO SOCIAL, FAMILIAR E DE TRABALHO - EXPECTATIVAS, ESTRATÉGIAS E ATITUDES}

Embora a hanseníase seja uma doença que, uma vez tratada, mostra possibilidades significativas de cura e não apresenta risco de contágio, ainda persiste uma situação moderada de estigma em relação à doença, em função de preconceitos profundamente arraigados.

O termo estigma é utilizado segundo o conceito desenvolvido por Goffman, que encontra nele três tipos fundamentais: as abominaçōes do corpo, os defeitos de caráter e a proveniência social (nacionalidade, religiāo, casta etc.). É evidente que no contexto da hanseníase, o estigma refere-se ao descrédito, à desqualificação e à marginalização social em conseqüência das deformidades físicas do paciente.

Uma vez que um indivíduo é estereotipado com tal rótulo social, que significa a imposição de uma marca que, de um certo modo, o reduz a uma condição inferior ao padrão mínimo atribuído à condição humana, restaria a ele duas possibilidades: ou se adequar ao papel marginal a ele designado ou tentar "encobrir" as marcas que caracterizam o estereótipo estigmatizante.

Aceitar o papel social significaria, no Brasil, antes da segunda metade deste século, segregar-se da família e da sociedade e confinar-se num dos leprosários disponiveis, submetendo-se a um tratamento que não tinha qualquer possibilidade de controlar a doença. Na Índia, conforme o relato de Waxler, ${ }^{2}$ ainda hoje em dia, para um indivíduo socialmente reconhecido como leproso, não há alternativa ao abandono do emprego, à separação da família e à exclusão do meio social. Procurar uma cidade grande é tudo o que lhe resta, como mendigo.

Enquanto no meio cultural da Índia o individuo tende a conformar-se com o papel social a ele atribuído, nos Estados Unidos ele tende a agir agressivamente con-

1 Goffman, E. Estigma. Buenos Aires: Amorrortu, 1963.

2 WAXIER, N. E. Learning to be a Leper: a case study in the social construction of iliness. In: MiSHLER, E.

G. (Org.). Social Contexts of Health, Iliness \& Patient Care. Cambridge University Press, 1981. 
tra este tipo de estereótipo. No Brasil, a nossa pesquisa sugere que há uma forte tendência para o "encobrimento" da doença, com o apoio da família nuclear e dos serviços de saúde.

Como vimos anteriormente, a mudança de nome 'lepra' para 'hanseníase' concorreu positivamente para atenuar o estigma. No Centro de Saúde, o paciente é estimulado a encobrir e instruído a não contar sobre sua doença para seu meio social e de trabalho. Este consetho é seguido pela maioria dos indivíduos pesquisados. Com apenas três exceções, todas as famílias entrevistadas revelaram que evitam mencionar a respeito da doença para qualquer outro indivíduo fora do círculo mais íntimo da família.

Normalmente, o diagnóstico de hanseníase choca o paciente que, mesmo sabendo que se trata de uma doença curável e năo-transmissível, internaliza a necessidade de camuflar a verdade para os outros e passa a sentir o peso do estigma. A a liança com a família é considerada indispensável. A maioria dos doentes entrevistados considera que nunca notou preconceito entre os membros da família. Em três ocasiōes, no entanto, este preconceito foi explicitado, e em dois casos houve separação do casal (depois reconciliados) e uma exclusão do meio familiar. Trata-se de uma situação que reforça a idéia de estigma moderado existente em relação à doença. Este capítulo focaliza as estratégias e atitudes dos doentes e de seus familiares diante do estigma. Além disso, o capítulo traz à tona as estratégias diante do tratamento da doença e o impacto da mesma no modo de vida em geral. Os trechos de entrevistas abaixo revelam, inicialmente, as representaçōes $\mathbf{e}$ as atitudes mais gerais a respeito do estigma:

Quando soube da minha doença fiquei muito revoltado. Eu gosto muito de praia, mas nảo dá mais para ir com pessoas conhecidas. Eu tenho que andar sempre com camisa de manga comprida e não posso usar bermudas. Pior que tudo é não poder tomar cerveja com os amigos por causa dos medicamentos. Só de pensar no assunto, eu fico nervoso. Apesar disso, acredito na cura. (Doente, 29 anos, lojista)

Quando a gente vê o preconceito que existe com relação à hanseniase, a barreira que ela produz, então, a gente trata de se resguardar. Antes, os leprosos eram enxotados; hoje, o problema com a AIDS é muito maior, e a hanseníase passou a ser uma doença normal, mas mesmo assim é melhor evitar comentar com os outros sobre o assunto. (Doente, 40 anos, comerciante)

Sou portador de hanseníase há uns 30 anos. Quando minha mulher ficou sabendo, ela separou-se de $\mathrm{mim}$. Ela ficou preocupada com os filhos pequenos e foi embora. Mais tarde ela entendeu que a doença não é contagiosa, nós juntamos de novo e agora está tudo bem. (Doente, 64 anos, aposentado) 
Eu percebo muito preconceito contra o meu marido por causa da hanseníase. Aqui em casa, o pessoal diz que não tem, mas não é verdade. Eu percebo que eles evitam sentar onde ele senta, beber no mesmo copo e não querem lavar a roupa junto com a dele. (Comunicante, 26 anos, desempregada)

A atitude de encobrir a hanseníase perante os vizinhos e o meio social e de trabalho do doente é realizada com um cuidado ainda maior. O preconceito existe, e aqueles que năo se preocuparam em preservar a sua imagem social sofreram um processo de degradação ou mesmo exclusão ou, no caso de trabalho, demissão.

Este fator não está ligado exclusivamente à ignorância sobre o contágio da doença. Houve pronunciamentos de que, mesmo sabendo que não ocorre possibilidade de contágio, há uma atitude psicológica de aversão ao doente, como se ele, na acepção de Douglas, ${ }^{3}$ tivesse se tornado impuro e esta impureza trouxesse alguma forma de perigo. Mais uma vez, como ilustram os trechos de entrevistas abaixo, a AIDS é utilizada como termo de referência e se sobressai em relação à hanseníase:

Os vizinhos não sabem que tenho hanseníase porque não gosto de comentar. Quando me perguntam porque vou ao Centro de Saúde, digo que tenho uma anemia forte e estou fazendo um tratamento. Se alguém fica sabendo que tenho essa doença, vai espalhar para todo o mundo. Aqui em casa, ninguém fez nenhuma diferença comigo por causa da doença. (Doente, 62 anos, dona de casa)

Se os amigos, vizinhos e familiares ficassem sabendo da minha doença, eles iriam ficar ressabiados e se afastariam, o que não seria nada fácil para mim. O jeito é continuar tomando sempre os remédios, continuar o tratamento e agir como se nada tivesse acontecido. (Doente, 55 anos, aposentado)

Eu não contei sobre minha doença para toda minha família porque acho que é preciso ter alguma cautela. Eu me considero normal e gostaria de ser considerado assim. Eu não comento com vizinhos e amigos por causa do preconceito. Se alguém me vê tomando remédio, eu invento uma desculpa. Mentir aborrece a gente, mas não tem outro jeito. (Doente, 40 anos, pequeno empresário)

Meu filho pediu para que não contássemos para ninguém que ele tem essa doença. Se as pessoas ficassem sabendo, elas iriam ficar comentando e se afastariam dele e, por isso, é bom que elas não saibam. Se eu tivesse essa doença, eu também não iria contar para ninguém. A mesma coisa é com a

3 Douclas, M. Purity and danger. Harmondsworth: Penguin Books, 1966. 
AlOS, ninguém quer chegar perto de quem está doente, eu não chegaria. Eu sei que chegar perto não transmite a AlDS, mas mesmo assim, eu não chegaria. (Comunicante, 51 anos, do lar)

Os doentes que apresentam sinais mais pronunciados da doença, como manchas em partes visíveis do corpo ou, pior ainda, deformidades físicas como conseqüência de uma menor defesa do organismo, encontram-se numa situação de estigma que, mesmo distante do caso da Índia, os aproxima deste pólo mais radical de exclusão e marginalizaçāo. Para esses indivíduos tudo é muito mais difícil ou quase impossível, considerando-se situaçōes como: arranjar um emprego, ter amigos, conseguir uma namorada ou companheira e constituir uma família. Isolado, o indivíduo internaliza algum tipo de culpa. Mesmo quando ele é bem-sucedido em camuflar a doença, a preocupação de ser descoberto é constante. Felizmente, estes casos constituem uma minoria. A seguir, os trechos de entrevistas mostram como os doentes representam a sua condiçāo:

A hanseníase é uma doença enviada como castigo de Deus. Eu vivo me perguntando onde errei. Eu sou muito nervoso e revoltado por causa disso. Não tenho namorada e não gosto de sair de casa. As pessoas evitam se aproximar de mim por causa da deformação da minha mão esquerda. O que eu mais gostaria é de arranjar um trabalho e me sentir útil. Eu bebo para ficar mais calmo. (Doente, 23 anos, desempregado)

Quando foi diagnosticada a hanseníase em mim, contei para a minha mãe e outros parentes mais próximos com quem morava. Eles não falaram nada, mas eu pude perceber que eles não se sentiram bem, apesar de ter explicado que a doença não era contagiosa. Eles não fizeram nada para eu sair de casa, mas a situação começou a ficar chata e eu saí e vim morar nesta pensão. A minha mãe achou que eu peguei esta doença de mulheres da vida. Eu explicava o que o médico me disse, mas ela não entendia nada. Meu único consolo é saber que se fosse AIDS seria muito pior. (Doente, 24 anos, ajudante de pedreiro)

Quando tomo muito sol, queima o local das manchas e eu passo mal, mas não posso evitar de tomar sol porque trabalho como ajudante de pedreiro. A minha maior preocupação é os outros começarem a reparar. Se o meu patrão perceber, eu acho que ele me demite. (Doente, 24 anos, ajudante de pedreiro)

Eu fico muito triste vendo meus filhos sem emprego. Eles procuram por trabalho e não encontram. Dois deles são pedreiros e têm dificuldades de tra- 
balhar porque têm hanseníase e problemas com esforço físico. Um deles conseguiu recentemente um emprego, mas teve logo que parar por causa de uma crise de neurite. Quando voltou do tratamento, encontrou sua carteira assinada com demissão. Ele ficou com tanta raiva que parou o tratamento. A assistente social foi falar na firma dele, mas não resolveu nada. Por causa desse tipo de coisa, ele se tornou uma pessoa muito revoltada e ultimamente deu para beber todos os dias. (Doente, 60 anos, pensionista)

Um indivíduo ou sua família pode reagir ao diagnóstico da hanseníase como uma catástrofe terrivel, com indiferença ou com alivio. As razões para essas discrepâncias repousam, em boa medida, no nivel de educação e de renda a que pertence o doente. De um modo geral, encontramos o seguinte padrão: as famílias de classe média entrevistadas perceberam o diagnóstico como algo muito negativo, embora a maioria dos tipos de hanseníase nestes estratos sociais representem formas menos graves. Entre as famílias de classe baixa, a proporção daqueles que receberam o diagnóstico com indiferença ou mesmo com alívio foi consideravelmente maior, ainda que os tipos de hanseníase nestas camadas tendam a representar formas mais graves.

A razăo provável para essa discrepância repousa no fato de que para as famílias de nível educacional e de renda baixos, o diagnóstico de hanseníase não representa um estigma tăo forte quanto nas famílias de nivel educacional e renda mais altos. Entre estas últimas, o diagnóstico representa uma ameaça direta à imagem pública e ao sentimento de identidade que elas tentam projetar para o mundo social e para si mesmas. Não deixa de constituir um paradoxo o fato de famílias com melhor nivel de informação serem mais propensas a nutrir um preconceito desta natureza.

O papel humilde desempenhado na sociedade pelas familias de classe social mais baixa exige um investimento menor na imagem pública e, por esse motivo, o diagnóstico de hanseníase tende a se revelar como um problema maior apenas enquanto ameaça à capacidade de trabalho. Os trechos de entrevistas abaixo revelam que, entre estas famílias, é comum receber o diagnóstico com indiferença. Como revelam os trechos de entrevistas abaixo, quando há uma reação emocional de choque, ela ocorre não tanto pela ameaça a um sentimento de identidade quanto pela possibilidade de incapacitação física:

Quando meu genro contou que tinha hanseníase, a gente nem pensou que fosse algo ruim, porque os médicos insistiram que a doença tinha tratamento. Se tem cura, tudo bem, é como qualquer outra doença. Faz dois anos que ele segue o tratamento e já deve estar quase bom. (Comunicante, 51 anos, do lar) 
Quando soube que tinha hanseníase, não senti nada, eu me conformei. Eu não tenho nada desse negócio de ficar me lamentando. A gente não tem tempo para pensar muito no problema. Eu me preocupo mais com o que eu terei de por na mesa amanhä. (Doente, 62 anos, dona de casa)

Quando a minha mãe chegou do Centro de Saúde e contou que tinha a doença, a gente não teve nenhuma reação, nenhuma surpresa porque não é uma coisa para se desesperar. Desde que eu nasci, ela se queixa desse problema. Agora, que está sendo tratada, ela deve ficar melhor. O tratamento é demorado porque a doença ficou grave depois de tanto tempo. (Comunicante, 37 anos, ajudante de pedreiro)

Quando ouvi do médico que tinha hanseniase, fiquei apavorado, pois achei que fosse uma doença muito contagiosa e que fosse necessário o meu isolamento. A minha mulher precisou de algum tempo para me acalmar e me fazer ver que o problema não era tão grave como eu imaginava. A doença estava no início, não era contagiosa, o tratamento não levaria tanto tempo e a cura era uma certeza. (Ex-doente, técnico especializado, 53 anos)

Quando soube que estava com hanseniase, fiquei apavorada porque pensei que fosse começar a cair pedaço. Fiquei mais tranqüila quando o médico me explicou que não era assim. Mais tarde, percebi que a doença não mudou muita coisa em mim. Eu sou a mesma que eu era sem a doença. Nunca parei de trabalhar, é como se não tivesse a doença. (Doente, 62 anos, dona de casa)

Como um elo central que coordena e administra as estratégias de consumo em saúde encontra-se a família que, em última instância, controla os passos necessários para a decisão do que gastar. Cabe à mãe ou à dona de casa decidir se algum membro está doente, qual a gravidade da doença e se deve receber tratamento de algum tipo. ${ }^{4} \mathrm{O}$ fator econômico é, sem dúvida, importante na determinação da tomada de decisão, na medida em que configura e limita o universo de opçōes e o leque de possibilidades disponiveis. Outros fatores desempenham um papel não menos importante nesse sentido, destacando-se os aspectos culturais, a forma de organização familiar, além da situação de oferta de serviços públicos de saúde.

Nesse contexto, o campo de ação de um paciente é análogo ao de um mercado, onde se oferecem diferentes produtos confeccionados sob diferentes paradigmas e propostas ideológicas de cura, e onde, embora a medicina represente um va-

4 QufIRoz, M. S. Representaçōes sobre Saúde e Doença - agentes de cura e pacientes no contexto do SUDS. Campinas: Ed. UNICAMP, 1990. 
lor inquestionável, o comprometimento com ela é parcial e limitado pela concorrência com outras alternativas. ${ }^{5}$ Nesse esquema, o médico significa apenas uma dentre outras peças num tabuleiro complexo que, em último caso, é manipulado pela população.

No caso específico da hanseníase, embora a medicina religiosa tenha um papel significativo, como vimos anteriormente, o papel atribuído à medicina ocidental moderna é fundamental. Mesmo os que tentam outras vias, como verificamos com respeito aos que usam ervas medicinais ou aproximaçōes religiosas, raramente o fazem como alternativa, mas como um complemento:

Para outras doenças eu já experimentei chás caseiros e benzimento porque acredito que podem funcionar, mas não para a hanseníase. Nem me passa pela cabeça tentar qualquer outra coisa além do tratamento que recebo no Centro de Saúde. (Doente, 33 anos, motorista de caminhão)

Não adianta procurar qualquer tipo de tratamento para a hanseníase fora da medicina. A hanseníase é uma doença do sangue e dos nervos, não é do tipo que vem de mau-olhado. Por isso é preciso tratar com médico. (Doente, 42 anos, operário)

A partir do momento que soube da minha doença, eu comecei a seguir todas as recomendações dos médicos. Eu cortei imediatamente qualquer bebida alcoólica e evito tudo aquilo que fico sabendo que pode ser prejudicial para a saúde. Eu só penso em me recuperar e para isso sigo todas as recomendaçōes dos médicos. (Doente, 40 anos, comerciante)

A identificação de saúde com capacidade de trabalho e bem-estar, particularmente entre as famílias de classe social mais baixa, algumas vezes prejudica a percepção de que o tratamento para hanseníase realmente pode conduzir à cura. É estranho para essas famílias que um tratamento que, constantemente, causa indisposições e mal-estares possa, ao mesmo tempo, promover a cura. Em várias ocasiōes, as primeiras sensações negativas provocadas pelos medicamentos foram identificadas como um caso em que o médico não "acertou". Esta interpretação responde pela maioria dos casos de abandono do tratamento. As famílias de classe média, por sua vez, tenderam a aceitar as indisposições provenientes da medicação com maior naturalidade e mostrar menos dúvidas quanto à cura, embora a demora no tratamento freqüentemente tivesse provocado desânimo.

5 Bourdieu, P. A Economia das Trocas Simbólicas. Sāo Paulo: Perspectiva, 1975.

Beals, A. R. Strategies of Resort to Curers in South India. In: Leste, C. (Ed.) Asian Medical Systems, Berkeley: Un. of California Press, 1976. 
As famílias de classe social baixa mostraram-se muito mais propensas a abandonar o tratamento do que as famílias de classe social média e média-alta. O mesmo padrão repetiu-se no que diz respeito ao controle dos comunicantes, na confiança nas palavras dos médicos e na consistência em seguir o tratamento. Como já vimos, raramente os exercícios de fisioterapia são realizados por doentes pobres, que justificam essa atitude pelo fato de já fazer exercícios físicos em demasia no trabalho:

Eu me dei muito mal com o tratamento. Depois de quatro meses, fui a um outro médico num outro posto de saúde. O médico viu a mancha e achou que era micose e me deu um tratamento. já faz dois meses que estou passando as pomadas que ele receitou, mas não estou sentindo nenhuma melhora. Eu não contei para ele que o teste para hanseniase deu positivo porque é ele quem deveria fazer as perguntas. Eu torci para ter dado certo mas, como nāo deu, vou retornar ao Centro de Saúde. (Doente, 33 anos, operário)

Não quero mais saber de tratamento porque me dava muito mal com os remédios, eles me deixavam de um jeito que nāo podia mais trabalhar. Sem poder trabalhar, de onde é que eu iria tirar o meu sustento? Por isso eu larguei e não pretendo continuar. Eu sei que posso contaminar as crianças, mas o que posso fazer? Além disso, eu não acredito que tenho esta doença. No começo, os médicos trataram a ferida como úlcera. Só mais tarde, no Centro de Saúde, eles acharam que era hanseníase. Como eu não sei quem tinha razão, é meIhor deixar como está. (Doente, 58 anos, lavrador)

O único em casa que se preocupa com hanseníase é meu marido que, além de ir fazer o controle, sempre observa se aparece alguma mancha na pele. Ele se preocupa com o fato de meu pai năo querer fazer mais tratamento. Ele diz que precisa das mãos para trabalhar e se preocupa com a possibilidade de ter de parar. (Comunicante, 24 anos, do lar)

Eu não faço mais tratamento porque, no Centro de Saúde, eu tinha que ficar esperando mais de três horas para ser atendido e eu não tenho tempo. Por enquanto, o problema é só no nariz, e nariz tanto faz. Eu me sinto bem e se piorar, se pegar o braço e as pernas, eu vejo o que vou fazer. (Doente, 33 anos, caminhoneiro)

As percepçōes quanto ao impacto da doença no modo de vida variavam mais em função da gravidade da mesma. As formas de hanseníase mais deformantes tendem a ter um impacto muito maior, tanto entre as famílias de classe média como entre as de classe baixa. Como o atendimento médico no Centro de Saúde exige 
um longo período de espera, ele expõe ao doente casos mais graves da doença, o que freqüentemente causa medo, alivio (pelo caso pessoal ser menos grave) e maior apego ao tratamento. No entanto, entre os que abandonaram o tratamento, todos eles de classe social baixa, nem mesmo o fato de saber que a doença poderia piorar, levando a deformações incapacitantes, impediu a tomada de decisão em favor de uma perspectiva imediatista. É esta mesma atitude que leva os pacientes a só procurarem um médico quando o desenvolvimento da doença começa a ameaçar a capacidade de trabalho. É difícil, nestes casos, deixar de concordar com a teoria da cultura da pobreza, que explica que atitudes como esta são o resultado de uma percepção mais pontual e imediatista da vida:

No geral, a doença não modificou muito a minha vida que segue do mesmo modo que antes. Eu não teria condiçōes de mudar se fosse preciso. Como é que eu poderia encontrar uma outra profissão nessa altura da vida? (Doente, 33 anos, motorista de caminhão)

Quando eu fazia tratamento, eu morria de medo dos demais pacientes que encontrava no Centro de Saúde, porque a gente via o estado deles, aqueles velhinhos com o pé inchado, com manchas e feridas feias. $O$ estado da gente era normal perto deles. (Ex-doente, 33 anos, cozinheira)

A única coisa que a doença modificou na nossa vida foi o sexo. Ele me procura muito menos e é menos carinhoso. Acho que ele ficou nervoso e inseguro. (Comunicante, 26 anos, desempregada)

A doença modificou tudo na minha vida. Eu tive que deixar de trabalhar, perdi o gosto de ir a bailes e encontrar uma namorada e, também, a esperança de cura depois de quatro anos de tratamento sem resultado. Para ser franco, com a vida que eu tenho, não me sinto nada feliz. Para melhorar o programa de hanseniase, acho que deveria haver mais reunião de médicos com doentes para explicar a doença e o tratamento. (Doente, 28 anos, aposentado) 


\section{CONCLUSÃO}

Esta pesquisa mostra, antes de tudo, a baixa prioridade que a hanseníase tem recebido por parte da sociedade em geral e da medicina em particular. Embora dados epidemiológicos revelem que esta endemia esteja crescendo no Brasil a uma grande velocidade, esta informação não parece sensibilizar a sociedade e o poder público no sentido de promover um enfrentamento do problema.

A reforma do sistema de saúde promovida no País que desembocou no SUS, ao mesmo tempo que impôs um sistema descentralizado e municipalizado destruiu o sistema centralizado e autoritário na Saúde Pública e, dentro desta, o modelo hegemônico da dermatologia sanitária no controle da hanseníase. A política implementada pelo SUS pretende descentrar o diagnóstico e o tratamento desta doença através de toda a rede básica de serviços de saúde e, com isso, diluí-la no quadro geral de morbidade. Ainda que esta medida tenha um efeito positivo na desestigmatizaçăo da doença, a falta de recursos tem causado um nivelamento por baixo junto às demais morbidades, deixando-a em pior situaçăo do que se encontrava no modelo anterior.

O sistema de saúde como um todo encontra-se em crise pela impossibilidade de gerar recursos suficientes para dar conta dos custos crescentes do serviço médico-hospitalar. Embora o hospital e a alta tecnologia em que se baseia estejam no centro da crise, o setor mais prejudicado tem sido o serviço público relacionado com a medicina coletiva (controle de vetores, instituições de pesquisa, produção de imunobiológicos, de medicamentos e medicina preventiva), que foi praticamente sucateado depois de muito tempo de investimentos baixíssimos. Nada indica que esta situação possa ser revertida com o avanço do SUS, cuja forma de pagamento do serviço médico privilegia o pronto-atendimento sob a ótica do profissional médico, ou seja, o aspecto biológico e individual da doença.

Um município do porte de Campinas, que contribui para o financiamento do setor saúde com o equivalente a um terço de tudo o que é gasto e que poderia "pôr mais peso" em programas de saúde de maior abrangência do que no pronto-atendimento, reproduz a influência biologicista e individualizante propagada pelo Gover- 
no federal, concentrando cerca de $95 \%$ de seus gastos no pronto-atendimento clínico individual. A forma de pagamento dos serviços de saúde implementada pelo SUS dificulta a relocação da dimensão biológica da medicina num âmbito dependente de objetivos sociais. Com o domínio da medicina curativa na rede básica de serviços de saúde, a saúde pública e a medicina preventiva e social continuam a desempenhar um papel secundário e submisso a uma postura que não mais se legitima em nível teórico.'

Quebrar abruptamente esta lógica é, numa interpretação corroborada pelos técnicos da Secretaria Municipal de Saúde, difícil devido a questōes que vão desde a forma de financiamento do nivel federal para a saúde até a legislação municipal que estimula a contratação de médicos e dentistas, dificultando a de outros profissionais da saúde. As ações coletivas, por outro lado, são caras porque exigem estruturas permanentes e, freqüentemente, "inconvenientes" porque criticam o modelo de desenvolvimento econômico. Além disso, os resultados obtidos por este tipo de serviço não são imediatamente visiveis e nem facilmente percebidos, embora sejam indispensáveis para a melhoria das condições de vida e de saúde.

A rotatividade da mão-de-obra na rede, em função dos baixos salários, e a descontinuidade das políticas públicas decorrente da constante mudança de secretários da saúde têm sido os grandes problemas que afetam negativamente a rede pública de serviços de saúde, num contexto em que inexiste uma burocracia sólida $e$ autônoma. A constante mudança de médicos causa prejuízo para todas as doenças, mas principalmente para a hanseniase, que exige um treinamento específico e contempla um tratamento de longa duração. A confiança no profissional e o vínculo afetivo são aspectos importantes da clínica que se encontram prejudicados no serviço público de saúde.

Atualmente, o Centro de Saúde não tem e nem pretende desenvolver qualquer meio de coagir um doente infectante a se tratar. Isto reflete uma postura positiva quando se tem como parâmetro a tradição autoritária do sistema de saúde inaugurada por Oswaldo Cruz. No caso da hanseníase, esse autoritarismo, expresso no sistema de internamento compulsório em asilos, significou um período de terror para o doente e seus familiares. Ao mesmo tempo, esta postura implica uma omissão irresponsável quando se tem como referência a existência de meios não autoritários de persuasão, através de visitas de sanitaristas e psicólogos. Esta alternativa, contudo, encontra-se absolutamente além dos meios disponíveis ao serviço público de saúde. Sugerir que o sistema de saúde saia em busca de patologias e de tratamentos quando não consegue dar conta nem dos que procuram por ele, significa uma utopia na presente conjectura.

1 Ver, a respeito, QueIroz, M. S. \& VIANA, A. L. Organização e gerenciamento dos serviços de saúde: uma avaliaçâo da experiência de Campinas. In: Rev. Adm. Públ., 28(2): 61-70, Rio de Janeiro, 1994. 
A pretensão de descentralizar o atendimento para todas as unidades tem esbarrado no despreparo dos médicos para diagnosticar e tratar a hanseníase, o que resulta num problema sério, tendo em vista que o Brasil é um país endêmico e que por isso a hipótese diagnóstica deveria estar presente em qualquer consulta médica. A capacitação desses profissionais exigiria uma radical mudança, desde a estrutura do ensino médico, cuja percepção dominante da doença é hospitalocêntrica, até uma valorização do pagamento dos médicos do setor público. A implementação desta última medida teria o poder de evitar a grande rotatividade atualmente existente entre os médicos da rede pública, juntamente com a percepção de que o emprego neste setor é apenas um estágio a ser superado no desenvolvimento profissional.

A alta proporçăo de diagnósticos equivocados encontrados por esta pesquisa resulta da ignorância generalizada dos médicos em relação à hanseníase, um forte sintoma da năo-prioridade que esse tipo de doença representa para o sistema de educação médica. $O$ médico normalmente não tem condições de realizar o diagnóstico porque, além de não ter sido treinado para isso, não quer fazê-lo, uma vez que a hanseníase é uma doença que se afasta do paradigma dominante da medicina baseada no hospital e na alta tecnologia.

Por suas próprias características, a hanseníase, ao invés de alta tecnologia, requer um contato prolongado de uma equipe de profissionais da saúde com o paciente. Este contato, por sua vez, prevê um tratamento que inclui, mas não se limita ao mero aspecto biolológico. A situação de pobreza, de carência cultural, de desagregaçăo familiar, de subemprego, além dos problemas psicológicos específicos da doença relativos à rejeição e à baixa auto-estima, não só a acompanham, influindo decisivamente no tratamento e na cura, como também fazem parte de sua própria causa. É provável, nesse sentido, que a situaçāo de estresse promovida por estes fatores tenha concorrido para deprimir o sistema imunológico do paciente, predispondo-o a contrair a doença. Em realidade, a hanseníase só se torna doença quando associada com uma deficiência imunológica que se supōe ser de origem genética.

Os profissionais do Centro de Saúde são unânimes em reconhecer que o problema de depressão emocional causado pelas condiçōes de vida afeta negativamente o tratamento de qualquer doença, mas principalmente o da hanseníase. Embora identifiquem este fator $\mathrm{e}$, com isso, a necessidade de que o tratamento seja conduzido por uma equipe multiprofissional, os médicos consideram ser inevitável que a falta de recursos do setor público atinja particularmente esta área, que envolveria um trabalho mais intensivo de psicólogos, assistentes sociais e outros profissionais preocupados em perceber o processo saúde e doença no interior de uma perspectiva integral de vida. Embora partilhem do ideal de que a saúde e a doença devam ser percebidos num contexto que inclua dimensões mais amplas do que o mero aspecto biológico, os médicos são unânimes em afirmar que não se pode começar um sistema de saúde sem o aspecto biológico. As dimensōes sociais e psicológicas deverão 
ser acrescentadas paulatinamente, na medida em que o serviço receba mais recursos. Enquanto isso não for possível, o médico admite improvisar com os poucos recursos de que dispōe.

A precariedade do serviço de acompanhamento sociopsicológico conduz a um envolvimento precário com o tratamento e a uma pouca preocupação com os aspectos informativos e educativos, tanto por parte do paciente como do serviço de saúde. A pesquisa mostra que a maioria dos doentes e comunicantes pesquisados sabem muito pouco sobre a doença, ao mesmo tempo que reivindicam uma melhor comunicação com a equipe de saúde, visando um relacionamento mais harmônico com o processo de tratamento.

Esta reivindicação encontra-se perfeitamente integrada com uma visão que percebe a saúde e a doença como resultantes, em grande medida, do relacionamento do ser humano com o seu meio social, familiar e de trabalho. Outras pesquisas mostram que este tipo de representação é partilhada por muitas outras sociedades e culturas, inclusive sociedades complexas como mostra o estudo de Herzlich ${ }^{2}$ conduzido em Paris, um meio urbano cosmopolita. Ficar doente ou curar uma doença, segundo esta representação, depende do modo de vida tomado num sentido mais amplo que, sem negar os aspectos biológicos da doença e da cura, leva em conta a dimensão simbólica presente nos valores que dāo sentido à vida, à doença $\mathrm{e}$ à morte.

Ainda que haja um consenso nas ciências sociais, particularmente nas áreas da antropologia da medicina e sociologia da saúde, de que a compreensão da saúde e da doença não pode prescindir de fatores socioculturais, esta perspectiva só recentemente tem se aberto de um modo mais consistente para as ciências biológicas. No entanto, os estudos realizados com placebos, ${ }^{3}$ com a atitude emocional em relação à cura, e principalmente com o estresse, têm revelado aspectos que as ciências sociais, a psicologia e, ironicamente, as representaçōes do senso comum de muitas sociedades já conheciam, ou seja, o fato de que tanto a saúde como a doença dependem de componentes subjetivos e emocionais relacionados com a experiência de vida. Intervir nestas dimensōes pode ser eficaz para muitos problemas que a medicina insiste em focalizar sob o ponto de vista estritamente biológico. Capra ${ }^{4}$ fala com muita propriedade a respeito:

2 HerzuICH, C. Health and IIIness - a social psychological analysis. London: Academica Press, 1973.

3 Placebo é um medicamento inócuo, dado ao paciente como se fosse um comprimido autêntico, a fim de que ele pense estar recebendo o remédio verdadeiro. Diversos estudos mostraram que $35 \%$ dos pacientes apresentaram alívio satisfatório quando receberam placebos em vez da medicação regular para uma vasta gama de problemas médicos.

4 Capra, F. O Ponto de Mutaçāo - a ciência, a sociedade e a cultura emergente. Săo Paulo: Cultrix, 1993. 
Existe um elemento-chave no vínculo entre o estresse e a doença que ainda não é conhecido em todos os seus detalhes, mas que foi verificado por numerosos estudos: é o fato de que o estresse prolongado anula o sistema imunológico do corpo e suas defesas naturais contra infecçōes e outras doenças. $O$ pleno reconhecimento desse fato ocasionará uma importante mudança na pesquisa médica, fazendo com que ela deixe de lado a preocupação com microorganismos e passe a estudar, cuidadosamente, o organismo hospedeiro e seu meio ambiente. Tal mudança é vital em nossos dias, visto que as doenças crônicas e degenerativas - que são características do nosso tempo e constituem as causas principais de morte e incapacidade - estão intimamente relacionadas com o estresse excessivo. (Capra, 1993: 319)

Este livro pretendeu oferecer uma pequena contribuiçăo para a consolidação deste novo paradigma apontado por Capra, um paradigma que inclui o aspecto subjetivo e cultural da doença e destaca a importância do método qualitativo de investigação. O estudo das representaçóes sociais são indispensáveis nesta perspectiva e, através delas, acreditamos ter podido oferecer uma dimensão mais abrangente e, por isso mesmo, mais rigorosa sobre o problema da hanseníase.

Costaríamos de concluir assumindo que, para incorporar uma dimensão holistica da saúde e doença, em consonância tanto com as representações populares como com as investigaçōes científicas mais recentes sobre placebo e estresse, a medicina precisaria ampliar a sua base reducionista biológica e incluir dimensóes sociais e culturais no enfoque da saúde e da doença. Esta perspectiva teria um efeito duplo com relação à especificidade do nosso estudo. De um lado, ela responderia à demanda de grande parte da populaçáo e, de outro, muito provavelmente, produziria um impacto positivo no quadro epidemiológico de desenvolvimento da hanseníase. 


\section{REFERÊNCIAS BIBLIOGRÁFICAS}

ALVES, P. C. \& SOUZA, I. M. Escolha e avaliação de tratamento para problemas de saúde: o itinerário terapêutico. Texto apresentado no XVIII Encontro Anual da ANPOCS, 1994. (Mimeo.)

AROUCA, A. S. S. O dilema preventivista - contribuição para a compreensão e crítica da Medicina Preventiva. Campinas, 1975. Tese de Doutoramento. FCM-UNICAMP.

BEALS, A. R. Strategies of resort to curers in South india. In: LESLIE, C. (Ed.) Asian Medical Systems, Berkeley: Un. of California Press, 1976.

BERGER P. \& LUCKMANN, T. The social construction of reality. Harmondsworth: Penguin, 1979.

BOOSTEIN, R. C. A. Ciências Sociais e Saúde Coletiva: Novas Questōes, Novas Abordagens. In: Cad. Saúde Públ., 8(2): 140-149, Rio de Janeiro, 1992.

BOLTANSKI, L. As classes sociais e o corpo. Rio de Janeiro: Graal, 1984.

BOURDIEU, P. A economia das trocas simbólicas. São Paulo: Perspectiva, 1975.

CAMPINAS - Subsídios para a discussão do Plano Diretor. IE/UNICAMP, 1990.

CAPRA, F. O ponto de mutação - a ciência, a sociedade e a cultura emergente. Săo Paulo: Cultrix, 1993.

CLARO, L. B. L. Hanseníase: representaçōes sobre a doença. Rio de Janeiro: Ed. FIOCRUZ, 1995.

d'HOUTAND, A. \& FIELD, M. G. The image of Health: variations in perception by social class in a french population. In: Sociology of Health and Illness, 6(1), 1984.

DOUGLAS, M. Purity and Danger. Harmondsworth: Penguin Books, 1966.

DURHAN, E. R. A caminho da cidade. São Paulo: Perspectiva, 1975.

EHRENREICH, J. Introduction. In:

Review Press, New York, 1978.

(Ed.) The cultural crisis of modern medicine. Monthly

FELICIELLO, D. Modelos assistenciais e Política de Saúde no Brasil. In: Rev. Adm. Públ. 26(2): 62-78, Rio de Janeiro, 1992. 
FINE, P. E. Leprosy, the epidemiology of a slow basterium. Epidemiologic Reviews, 4: 161 $188,1982$.

GIOVANI, G. A questão dos remédios no Brasil. Săo Paulo: Polis, 1980.

CLUCKMAN, M. Custom and conflict in Africa. Oxford: Basil Blackwell, 1973.

GOFFMAN, E. Estigma. Buenos Aires: Amorrortu, 1963.

CONÇALVES, A. G. Epidemiologia e Controle da Hanseníase no Brasil, 1989. (Mimeo.).

HERZLICH, C. Health and Illness - a social psychological analysis. London: Academic Press, 1973.

JUNQUEIRA, L. A. P. \& INOJOSA, R. M. Gestăo dos serviços públicos de saúde. In: Rev. Adm. Públ., 26(2): 20-31, Rio de Janeiro, 1992.

LEAVELL, H. R. \& CLARCK, E. G. Medicina Preventiva. Rio de Janeiro: McGraw Hill, 1967.

LEWIS, O. Introdución a la vida. Ciudad de México: Ed. FCE, 1966.

LEWIS, O. The culture of Poverty. In: MOYNIHAN, D. P. (Ed.) On understanding Poverty. New York: Basic Books, 1969.

LÈVI-STRAUSS, C. Antropologia Estrutural. São Paulo: Tempo Universitário, 1970.

LOMBARDI, C. Hanseníase: epidemiologia e controle. São Paulo: Imprensa Oficial do Estado de São Paulo, 1990.

LUZ, M. T. Natural, racional, social - razâo médica e racionalidade científica moderna. Rio de Janeiro: Campus, 1988.

LUZ, M. T. Notas sobre as Políticas de Saúde no Brasil de transição democrática. In: Saúde em Debate, 32:27-32, junho, 1991.

MACHADO, F. A. Sugestōes para um Modelo Alternativo de Atenção à Saúde. In: Saúde em Debate, 31: 31-35, 1991.

MACHADO M. H. \& CARSALADE, M. I. Os trabaihadores em Saúde e o SUS. In: Rev. Adm. Públ., 26(2): 172-178, Rio de Janeiro, 1992.

MackEOWN, T. The role of Medicine: dream, mirage or nemesis. London: The Nuffield Provincial Hospitals Trust, 1979.

MERHY, E. E. A Saúde Pública como Política - um estudo de formuladores de políticas. São Paulo: Hucitec, 1991.

MERHY, E. E. \& QUEIROZ, M. S. Saúde Pública, Rede Básica e o Sistema de Saúde Brasileiro. In: Cad. Saúde Públ., 9(2): 177-184, Rio de Janeiro, 1993.

MINISTÉRIO DA SAÚDE/Secretaria Nacional de Programas Especiais em Saúde Divisão Nacional de Dermatologia Sanitária. Controle da hanseníase: uma proposta de integração ensino-serviço. Rio de Janeiro: OMS/NUteS, 1989.

MONTEIRO, P. Da Doença à desordem: a magia na Umbanda. Rio de Janeiro: Graal, 1985.

NAVARRO, V. A critique of the ideological and political position of the Brandt Report and Alma Ata Declaration. In: Int. Jo. Med. Serv., 14: 159-72, 1984. 
NOUSSITOU, F. M.; SANSARRICQ, H.; WALTER, J. A lepra na criança. Itália. Associazione Italina "Amici di Raoul Follereau", 1981.

OLIVEIRA, A. M. F. Os dilemas da municipalização da Saúde no contexto de uma região metropolitana: o caso de Campinas. Tese de Doutoramento. IE/UNKCAMP, 1995.

ORGANIZAÇĀO PAN-AMERICANA DA SAÚDE. Manual para o controle de lepra. 2.ed. Washington D. C., 1989.

PAIM, J. S. Reforma Sanitária e a Municipalização. In: Saúde e Sociedade, 1(2): 29-47, Săo Paulo, 1992.

POWLES, J. On the Limitations of Modern Medicine. In: MECHANIC, D. (Ed.) Readings in Medical Sociology. p. 18 45, The Free Press, New York, 1980.

QUEIROZ, M. S. Hot and cold classification in Traditional Iguape Medicine. In: Ethnology, 23(1): 63-71, Pithsburgh, 1984.

QUEIROZ, M. S. Representaçōes sobre Saúde e Doença - agentes de cura e pacientes no contexto do SuDs. Campinas: Ed. UNICAMP, 1990.

QUEIROZ, M. S. O Desenvolvimento da municipalização dos Serviços de Saúde em Campinas. In: Rev. Adm. Públ., 28(4): 27-37, Rio de Janeiro, 1994.

QUEIROZ, M. S. \& VIANA, A. L. Organização e gerenciamento dos serviços de saúde: uma avaliação da experiência de Campinas. In: Rev. Adm. Públ., 28(2): 61-70, Rio de Janeiro, 1994.

QUEIROZ, M. S., CASTRO, M. H. G. \& VIANA, A. L. A organização dos serviços de saúde: uma avaliação da experiência de Campinas. In: Cadernos de Pesquisa, 26, NePp/UNICAMP, p. 1-78. Campinas, 1993.

ROTBERG, A. Noçôes de hanseniologia. São Paulo: Fundação Paulista contra Hanseníase, 1979.

SAHLINS, M. Culture and practical reason. Chicago: The Un. of Chicago Press, 1976.

SEADE. Perfil Municipal. São Paulo, 1993.

SHUTZ, A. Collected Papers I: The problem of social reality. The Hague: Martinus Nijhoff, 1973.

SOMARRIBA, M. M. G. Community Health and Class Society: the health programm of norte de Minas, Brazil. Ph.D. Thesis, Sussex: University of Sussex, 1978.

SOUZA ARAÚjO, H. C. História da lepra no Brasil. Rio de Janeiro: Departamento de Imprensa Nacional, 1956.

SPINK, M. J. Desvendando as teorias implícitas: uma metodologia de análise das representações sociais. In: JOVCHELOVITCH, S. \& GUARESCHI, P. (Orgs.) Textos em Representaçōes Sociais, Petrópolis: Vozes, 1994.

STARR, P. The social transformation of american medicine. New York: Basic Books, 1982.

TALHARES, S. \& NEVES, R. G. Hanseníase. ISEA - Instituto Superior de Estudos da Amazônia, 2.ed., 1989. 
TURNER, V. W. Schism and contiuity in an african society: a study of Ndembu village life. Manchester: Manchester Un. Press, 1957.

TURNER, V. W. Muchona the hornet, interpreter of religion. In: CASAGRANDE, J. B. (Ed.). in the company of man. New York: Harper, 1960.

WAXLER, N. E. Learning to be a Leper: a case study in the social construction of illness. In: MISHLER, E. G. (Org.). Social contexts of health, illness \& patient care. Cambridge University Press, 1981.

WEBER, M. The sociology of religion. London: Methuen, 1966.

WEBER, M. A objetividade do conhecimento nas ciências e na política social. Lisboa: Ed. Lisboa Ltda., 1974.

WEBER, M. A ética protestante e o espirito do capitalismo. São Paulo: Pioneira, 1985.

WORSLEY, P. M. Marxism and culture: the missing concept. In: Occasional Paper, 4, Department of Sociology, University of Manchester, 1982.

ZALUAR, A. A máquina e a revolta. São Paulo: Brasiliense, 1985. 


\section{OUTROS TíTULOS DA EDITORA FIOCRUZ EM CATÁLOGO*}

- Estado sem Cidadãos: Seguridade Social na América Latina. Sônia Fleury, 1994. 249p.

- Saúde e Povos Indigenas. Ricardo Santos \& Carlos E. A. Coimbra (Orgs.), 1994. 251p.

- Saúde e Doença: um olhar antropológico. Paulo César Alves \& Maria Cecília de Souza Minayo (Orgs.), 1994. 174p.

- Principais Mosquitos de Importância Sanitária no Brasil. Rotraut A. G. B. Consoli \& Ricardo Lourenço de Oliveira, 1994. 174p.

- Filosofia, História e Sociologia das Ciências l: abordagens contemporâneas. Vera Portocarrero (Org.), 1994, 268p.

- Psiquiatria Social e Reforma Psiquiátrica. Paulo Amarante (Org.), 1994. 202p.

- O Controle da Esquistossomose. Segundo relatório do Comitê de Especialistas da OMS, 1994. 110p.

- Vigilância Alimentar e Nutricional: limitações e interfaces com a rede de saúde. Inês Rugani R. de Castro, 1995. 108p.

- Hanseníase: representações sobre a doença. Lenita B. Lorena Claro, 1995. 110p.

- Oswaldo Cruz: a construção de um mito nạ ciência brasileira. Nara Britto, 1995. 111p.

- A Responsabilidade pela Saúde: aspectos jurídicos. Hélio Pereira Dias, 1995. 68p.

- Sistemas de Saúde: continuidades e mudanças. Paulo M. Buss \& Maria Eliana Labra (Orgs.), 1995. 259p.

- Só Rindo da Saúde. Catálogo de Exposição Itinerante de mesmo nome, 1995. 52p.

- A Democracia Inconclusa: um estudo da Reforma Sanitária brasileira. Silvia Cerschman. 1995. 203p.

- Atlas Geografico de las Malformaciones Congénitas en Sudamérica. Maria da Graça Dutra (Org.), 1995. 144p.

- Ciência e Saúde na Terra dos Bandeirantes: a trajetória do Instituto Pasteur de São Paulo no período 1903-1916. Luiz Antonio Teixeira, 1995. 187p.

- Profissōes de Saúde: uma abordagem sociológica. Maria Helena Machado (Org.), 1995. $193 p$.

- Recursos Humanos em Saúde no Mercosul. Organização Pan-Americana da Saúde, 1995. $155 \mathrm{p}$.

- Tópicos em Malacologia Médica. Frederico Simões Barbosa (Org.), 1995. 314p.

- Agir Comunicativo e Planejamento Social: uma crítica ao enfoque estratégico. Francisco Javier Uribe Rivera, 1995. 213p.

- Metamorfoses do Corpo: uma pedagogia freudiana. Sherrine Njaine Borges, 1995. 197p.

- Política de Saúde: o público e o privado. Catalina Eibenschutz (Org.), 1996. 364p.

- Formação de Pessoal de Nível Médio para a Saúde: desafios e perspectivas. Escola Politécnica de Saúde Joaquim Venâncio (Org.), 1996. 222p.

" por ordem de lançamento/ano. 
- Tributo a Vênus: a luta contra a sifflis no Brasil, da passagem do século aos anos 40 . Sérgio Carrara, 1996. 339p.

- O Homem e a Serpente: outras histórias para a loucura e a psiquiatria. Paulo Amarante, 1996. 141p.

- Raça, Ciência e Sociedade. Ricardo Ventura Santos \& Marcos Chor Maio (Orgs.), 1996. 252p. (co-edição com o Centro Cultural Banco do Brasil)

- Biossegurança: uma abordagem multidisciplinar. Pedro Teixeira \& Silvio Valle (Orgs.), 1996. 364p.

- VI Conferência Mundial sobre a Muther. Série Conferências Mundiais das Naçōes Unidas, 1996. 352p.

- Prevención Primaria de los Defectos Congénitos. Eduardo E. Castilla, Jorge S. Lopez-Camelo, Joaquin E. Paz \& lêda M. Orioli, 1996. 147p.

- Clínica e Terapêutica da Doença de Chagas: uma abordagem prática para o clínico geral. João Carlos Pinto Dias \& José Rodrigues Coura (Orgs.), 1997. 486p.

- Do Contágio à Transmissão: ciência e cultura na gênese do conhecimento epidemiológico. Dina Czeresnia, 1997. 120p. 
MPRESSAO E ACABAMENTO

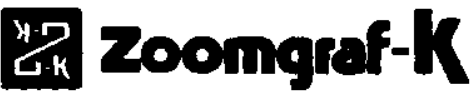

Av. Jansen de Mello, 403 - Niteró

CEP: 24030-020 - RJ - Brasil - 1997

Tels.: PABX (021) 620-2277

Fax: 620-5619 